\title{
A MATHEMATICAL MODEL OF NUTRIENT DISTRIBUTION IN COASTAL WATERS
}

\author{
By \\ EILEEN E. HOFMANN \\ LEONARD J. PIETRAFESA \\ LARRY P. ATKINSON \\ GUSTAV-A. PAFFENHÖFER \\ and \\ WILLIAM M. DUNSTAN
}

REPORT NO. 77-2

FEBRUARY, 1977

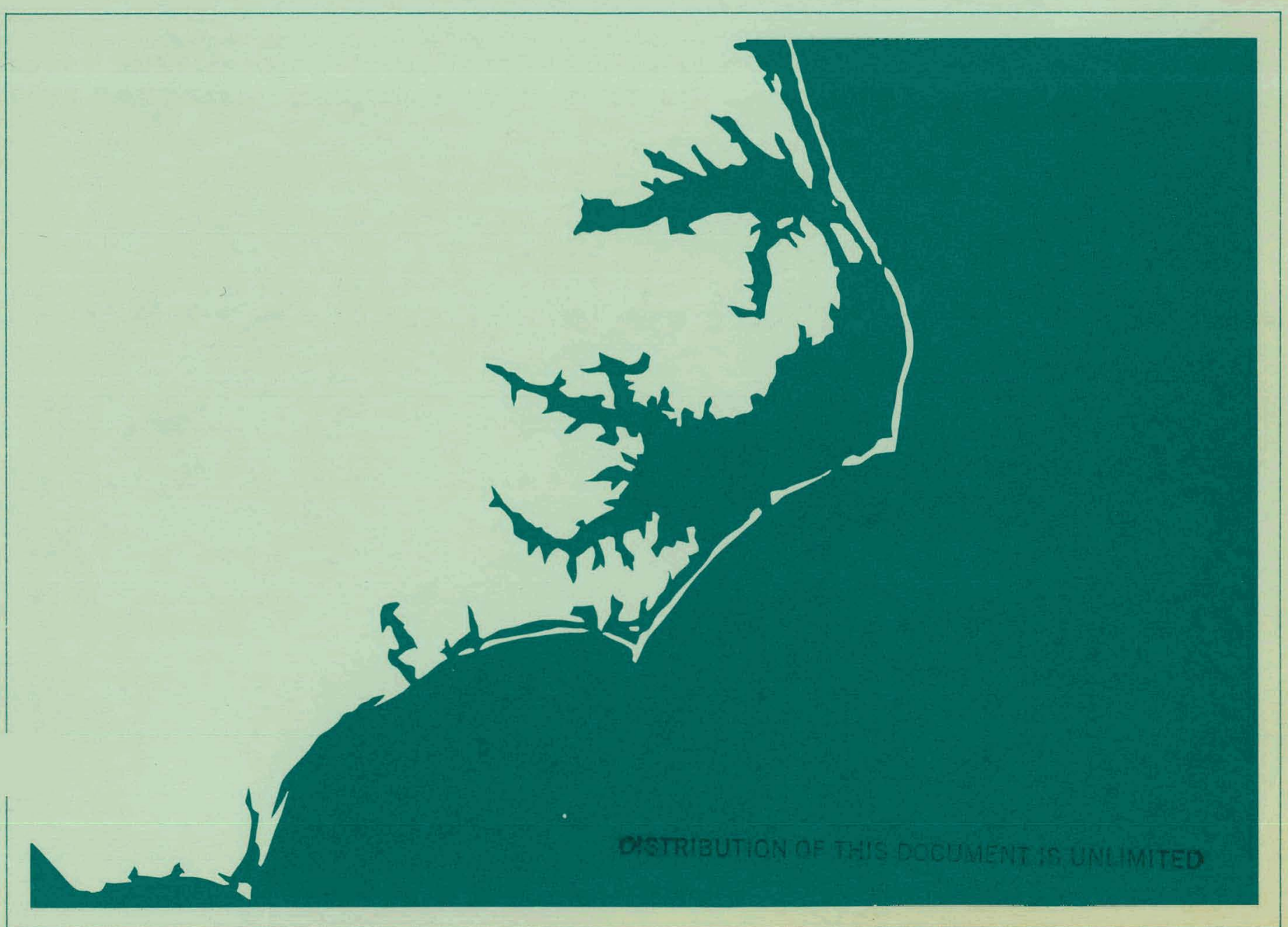




\section{DISCLAIMER}

This report was prepared as an account of work sponsored by an agency of the United States Government. Neither the United States Government nor any agency Thereof, nor any of their employees, makes any warranty, express or implied, or assumes any legal liability or responsibility for the accuracy, completeness, or usefulness of any information, apparatus, product, or process disclosed, or represents that its use would not infringe privately owned rights. Reference herein to any specific commercial product, process, or service by trade name, trademark, manufacturer, or otherwise does not necessarily constitute or imply its endorsement, recommendation, or favoring by the United States Government or any agency thereof. The views and opinions of authors expressed herein do not necessarily state or reflect those of the United States Government or any agency thereof. 


\section{DISCLAIMER}

Portions of this document may be illegible in electronic image products. Images are produced from the best available original document. 
NOIICE

THIS DOCUMENT WAS PREPARED AS AN ACCOUNT OF WORK SPONSORED BY THE UNTED STATES GOVERNMENT, NEITHER THE UNITED STATES NOR THE UNITED STATES ENERGY RESEARCH AND DEVELOPMENT ADMINISTRATION, NOR ANY OF THEIR EMPLOYEES, NOR ANY OF THEIR CONTRACIORS, SUECONTRACIORS, OR THEIR EMPLOYEES, MAKES ANY WARRANTY, EXPRESS OR MMPLIED, OR ASSUMES ANY LEGAL LIABILIIY OR RESPONSIBHITY FOR THE ACCURACY, COMPLEIENESS OR USEFULNESS OR ANY INFORMATION, APPARATUS, PRODUCT OR PROCESS DISCLOSED, OR REPRESENTS THAT ITS USE WOULD NOT INFKINGE PRIVATEIY OWNED RIGHTS. 


\title{
CENIER FOR MARINE AND COASTAL STUDIES
}

NORTH CAROLINA STATE UNIVERSITY

RALEIGH, NORTH CAROLINA

\section{A MATHEMATICAL MODEL OF NUTRIENT DISTRIBUTION IN COASTAL WATERS}

\section{by}

\author{
Eileen E. Hofmann*, \\ Leonard J. Pietrafesa*, \\ Larry P. Atkinson**, \\ Gustav-A. Paffenhöfer** \\ and \\ William M. Dunstan**
}

Report No. 77-2

February, 1977

* center for marine and coastal studies

NORTH CAROLINA STATE UNTVERSTTY

RAIEIGH, NORTH CAROLINA 27607

* *SKTDAWAY INSTTTUTE OF OCEANOGRAPHY

SAVANNAH, GEORGIA 31406

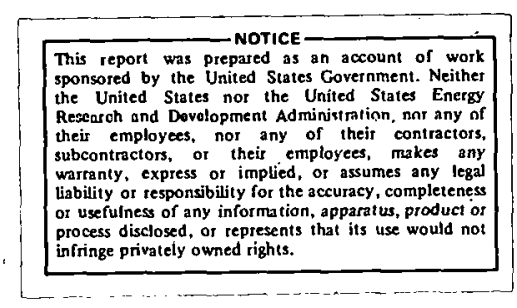

This work was supported by the Energy Research and Development Administration under Contract No. $E(38-1)-902$. 
An approach to blological modelling involving the use of separation transformation theory has been developed. By use of the theory, it is possible to reduce the number of independent variables in the system. The original four dimensional system $(x, y, z, t)$ can be reduced to a vertical plane conceptual model by assuming along isobath homogeneity in the flow fleld as a partial function of the baroclinic flow fleld. Both temporally dependent and independent nitrate concentration equations are then obtained and solved by conventional approximation methods.

This technique has applicability to ecological modelling and results obtained by its use show good agreement with field data. Parameterization of the physical processes shows horizontal diffusion and advection to be the important forces in the system. Scaling of biological dynamics show nutrient uptake by phytoplankton and detrital decomposition to be the most important biological factors in the system.

This technique permits the testing of various hypotheses with a minimum amount of computer time. 
PROJECT PERSPECTIVE

This report presents an aspect of an effort to understand "the continental shelf processes effecting the oceanography of the South Atlantic Bight" in an interdisplinary fashion. In 1975 an Energy Research and Development Administration (ERDA) sponsored study to address cause/effect questions concerning the continental margin oceanography between Cape Hatteras and Cape Canaveral was begun. North Carolina State University and the Skidaway Institute of Oceanography have subsequently co-ordinated biological, chemical and physical programs and this is one product of that co-operative effort.

This work was supported by the Energy Research and Development Administration under Contract No. E(38-1)-902. 
TABLE OF CONTENTS

Page

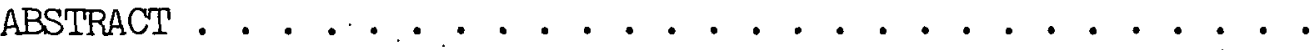

PROJECT PERSPECTIVE . . . . . . . . . . . . . . . 1 .

LIST OF TABLES . . . . . . . . . . . . . . . . . vi

LIST OF FIGURES . . . . . . . . . . . . . . . . vii vi v

LIST QF APPENDIX FIGURES . . . . . . . . . . . . . . . .

IINTKUDUCTION AIND REVIEW OF LITERATURE . . . . . . . . . . . . I 1

AREA OF STUDY ....................... 3

FIELD PROGRAM . . . . . . . . . . . . . . . . 6

INTRUSION PROCESS .................... 8

SYSTEM REPRESENTATION . . . . . . . . . . . . . . . 27

Uptake Term . . . . . . . . . . . . . . . . . . 29

Extracellular Release by Phytoplankton ........ . 31

Zooplankton Excretion .............. 33

Excretion by Fish ................ . . . 34

Decomposition of Detritus ............. 36

Nitrogen Fixation by Blue Green Algae . . . . . . . . . 41

Regeneration of Nitrate from Bottom Sediments . . . . . . 41

Scaling of Biological Dynamics . . . . . . . . . . 44

THE MATHEMATICAL APPROACH . . . . . . . . . . . . 46

CIRCULATION PATTERN. . . . . . . . . . . . . . . 50

Bottom Profile . . . . . . . . . . . . . . . 57

DISCUSSION OF RESULTS . . . . . . . . . . . . . . . 59

Advection and Diffusion l'erms . . . . . . . . 59

$\Lambda$ dveotively Dominant System . . . . . . . . . . . 59

Diffusively Dominant System . . . . . . . . . . . 60

Advectively-Diffusively Balanced System . . . . . . . 60

Advection and Horizontal Diffusion . . . . . . . . 62

Varying Bottom Topography . . . . . . . . . . . . 73

Complete Sýstem . . . . . . . ......... 73

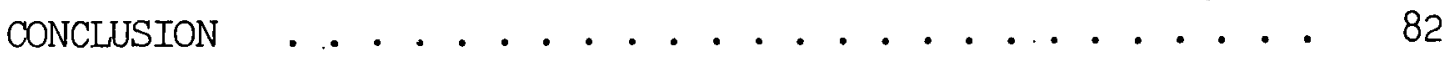

LIST OF REFERENCES . . . . . . . . . . . . . . . . . 84 
TABLE OF CONTENTS (continued)

Page

APPENDICES •

Appendix A. Computer Program . . . . . . . . . . . 90

Appendix B. List of Symbols and Their Values . . . . . . 94 
$v i$

\section{LIST OF TABLES}

Page

1. Chemical characteristics of water . . . . . . . . . . 32

2. Sediment-water nutrient flux • . • . • . . . . . . . . . 43 


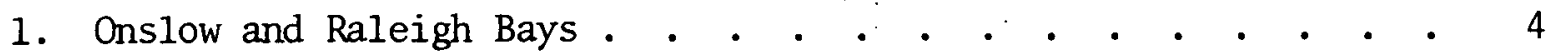

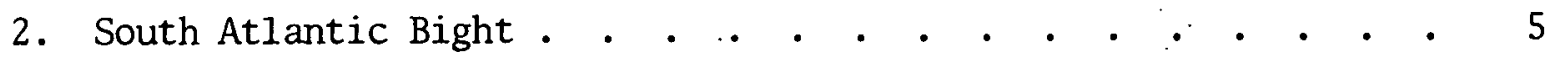

3. Average monthly wind speed $(-)$ and direction

$(0-0)$ for land stations from Cape Hatteras

to Cape Canavera1 . . . . . . . . . . • . . . . 11

4. Schematic diagram showing intrusion as described by Blanton (1971) . . . . . . . . . . . 13

5. Location map showing position of current meter moorings in Onslow Bay . . . . . . . . . . . 14

6. Progressive vector diagram : • • • • • • • • • • • • 15

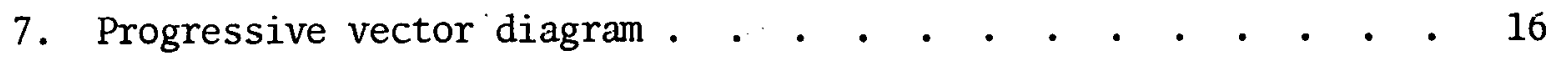

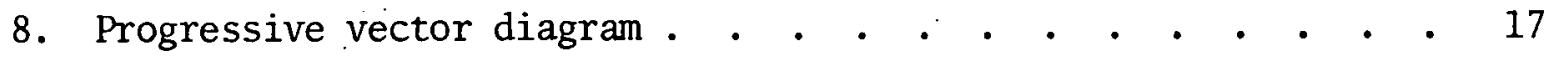

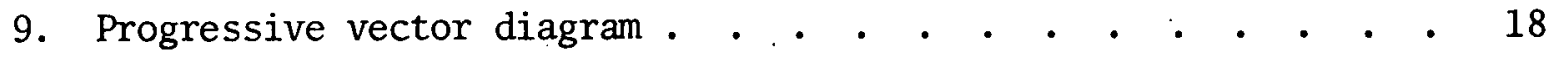

10. Progressive vector diagram . • • • . • • • •

11. Cruise tract, OBIS I: 6-7 August 1975 . . : . • . • • . 20

12. Vertical distribution of temperature

(XBT Grid, 6.-7 August 1975) • • • • • • . • • • . 21

13. Vertical distribution of nitrate, phosphate

and silicate (Hydro Grid 6-7 August 1975) • • • • • • . 21

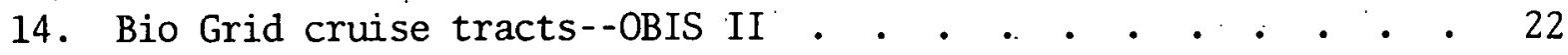

15. Vertical distribution of temperature

(Bio Grid, OBIS II, September 1975) • • . . . • . . . 23

16. Vertical distribution of chlorophyll a

(Bio Grid, OBIS II, September 1975) • • • • . • • • • • 23

17. Cruise tracts--OBIS IV: $8-11$ December 1975 •

18. Vertical distribution of temperatures

(XBT and Hydro Grids, 8-10 December 1975) • • . • . . . 25

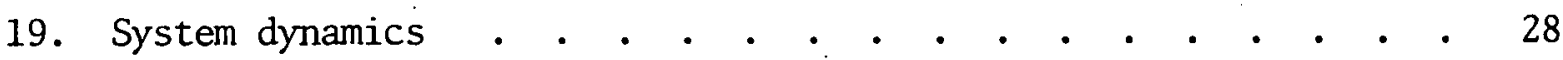


viii

LIST OF FIGURES (continued)

Page

20. Particle volume versus particle size . . . . . . . . 37

21. Particle volume versus particle data . . . . . . . 38

22. Particle volume versus particle size . . . . . . . . 39

23. Total POC ( $\mu \mathrm{g} \mathrm{C} / 1$ ) versus total 40

24. Horizontal and vertical velocity profiles

for a northeasterly wind of 1 dyne $/ \mathrm{cm}^{2}$. . . . . . 53

25. Horizontal and vertical velocity profiles

for a southwesterly wind of 1 dyne $/ \mathrm{cm}^{2}$. . . . . . . 54

26. Horizontal and vertical velocity profiles

for a southeasterly wind of 1 dyne $/ \mathrm{cm}^{2}$. . . . . . . 55

27. Horizontal and vertical velocity profiles

for a northwesterly wind of $1 \mathrm{dyne} / \mathrm{cm}^{2}$

28. Bottom profile generated with

$\alpha=-.4$ and $-1.2 . . .5 . . .58$

29. Diffusively dominant system . . . . . . . . . 61

30. Advectively-diffusively balanced system . . . . . . 63

31. Advection and horizontal diffusion with a southwesterly wind . . . . . . . . . . 64

32. Advection and horizontal diffusion with a southwesterly wind and different bottom profile . . . . . . . . . 65

33. Advection and horizontal diffusion with a northwesterly wind . . . . . . . . . . 67

34. Advection and horizontal diffusion with a southeasterly wind . . . . . . . . . . 68

35. Advection and horizontal diffusion with a northeasterly wind . . . . . . . . . . . 69

36. Advection and horizontal diffusion with an easterly wind . . . . . . . . . . . 70 
LIST OF FIGURES (continued)

Page

37. Advection and horizontal diffusion with an easterly wind and

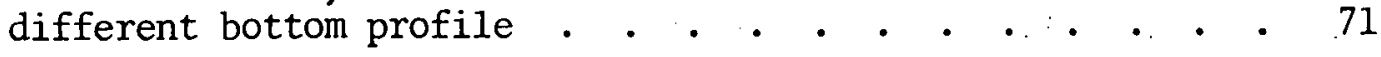

38. Varying bottom topography, $\alpha=-.6$. . . . . . . . . . 74

39. Varying bottom topography, $\alpha=-.8$. . . . . . . . . . 75

40. Varying bottom topography, $\alpha=-1.0$. . . . . . . . . 76

41. Complete system with $\alpha=-.6$. . . . . . . . . . . . . 77

42. Complete system with $\alpha=-.8$. . . . . . . . . . . 78

43. Complete system with $\alpha=-1.0$. . . . . . . . . . . 79

44. Bottom profile of Onslow Bay . . . . . . . . . . . 81 
LIST OF APPENDIX FIGURES

Page

\section{Appendix A}

1. Main program . . . . . . .

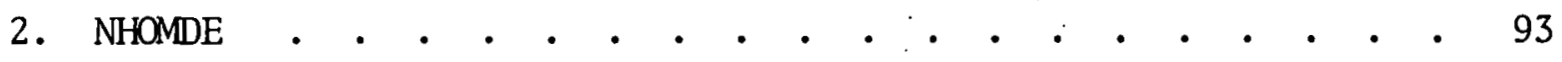




\section{CHAPTER I \\ INTRODUCTION AND REVIEW OF LITERATURE}

Mathematical symbols provide a useful shorthand for describing complex ecological systems, and equations permit formal statements of how ecosystems components are likely to interact. The mathematical model developed in this way is an imperfect and abstract representation of the real world. However, by providing an abstract and simplified description of a system, a model may then be used to guide research efforts or outline a problem for more detailed study.

The development of mathematical models for ecological systems began with the classic prey-predator equations of Lotka (1925) and Volterra $(1927,1927 a)$. Since then, marine scientists have attempted to describe processes of biological production in the ocean by formulating equations which represent the interactions of biological elements with their environment (O'Brien and Wroblewski, 1973). Patten (1968) has prepared a comprehensive review article on mathematical models of plankton production.

Investigations of dynamics of marine systems have followed two approaches. Energy flow studies (Odum, 1957; MacFadyen, 1964) have provided significant contributions to the understanding of aquatic ecosystem energetics. A second approach concerns studies of the cycling of minerals through the biotic and abiotic components of the system (Dugdale and Goering, 1967; Gerking, 1962; O'Brien and Wroblewski, 1973). Odum (1962) demonstrated the interconvertibility of these two approaches.

The purpose of this study is to develop a mathematical model of nutrient distribution in continental shelf waters for time periods on 
the order of several days as a function of physical and biological forces. The mathematical technique of Separation Transformation and concepts from vertical plane circulation are used to formulate the model and parameterize the processes involved in system dynamics.

Conservation of mass within the marine system is a basic assumption. The total amount of nitrate in the system is accounted for by either mace tronsport into or out of the area, or uptake and release hy hinlogical components within the system.

The mechanism of wind-driven circulation, based on simple Ekman dynamics, is used to generate a circulation pattern such that nutrientrich waters are advected in at the bottom and surface waters are deflected offshore, i.e., an "intrusion". This introduction of nutrients allows for greater biological production in what are otherwise nutrientpoor waters. While regenerated nitrogen in the fortn of amnonia may sustain production on the shelf, it is believed that the nitrate introduced via an intrușion provides the stimulus needed to begin primary production (Dunstarn and Atkinsur, 1976).

This study strives to incorporate physical, biological and chemical processes into a single system. After formulization of biological dynamics, circulation patterns and initial conditions, calculations of vertical plane distributions of nitrate are performed using numerical methodis (Apperill $\mathrm{A}$ ).

This model. attempts to focus on the important interactions involved in an intrusion. However, insufficient knowledge of the physical and biological processes which are involved in an intrusion limits the accuracy with which this model reproduces nature. Hopefully, future work will answer the questions raised by this model. 
CHAPTER II

AREA OF STUDY

Onslow Bay is a cupsate geomorphic coastal feature situated between Capes Lookout and Fear on the North Carolina coast (Figure 1). In this portion of the South Atlantic Bight (Figure 2), the continental she1f is shallow and wide with an average depth of 20-35 meters. The width of the shelf is approximately 100 kilometers off Cape Fear and narrows to 65 kilometers off Cape Lookout. Because of these features, the wind and large tidal range are important forces in near-shore areas. Hydrographically, the Carolina Shelf is considered to be vertically well mixed in winter and moderately stratified in summer, while horizontal gradients tend to be strong in winter and weakest during the summer. There is no large source of fresh water along the Carolina Capes, except for occasional wind-driven incursions of Virginia coastal waters around Cape Hatteras and into Raleigh Bay (Stefansson et al., 1971).

Beyond the sheif, the continental slope drops quickly, with an incline of $3^{\circ}-4^{\circ}$ to depths greater than 1000 meters. The mean axis of the Gulf Stream is located parallel to the shelf break, over some weekly to seasona1 average. 


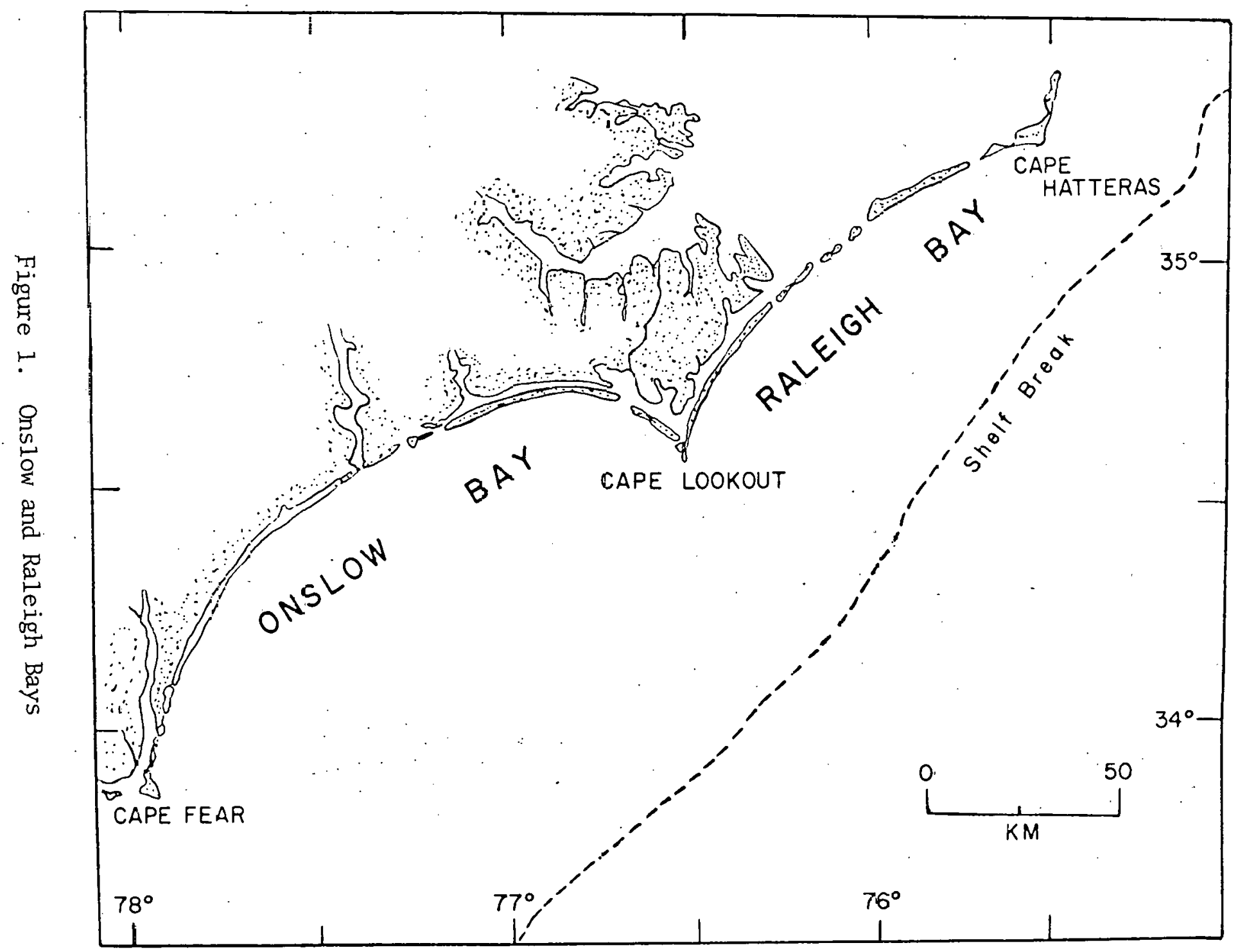




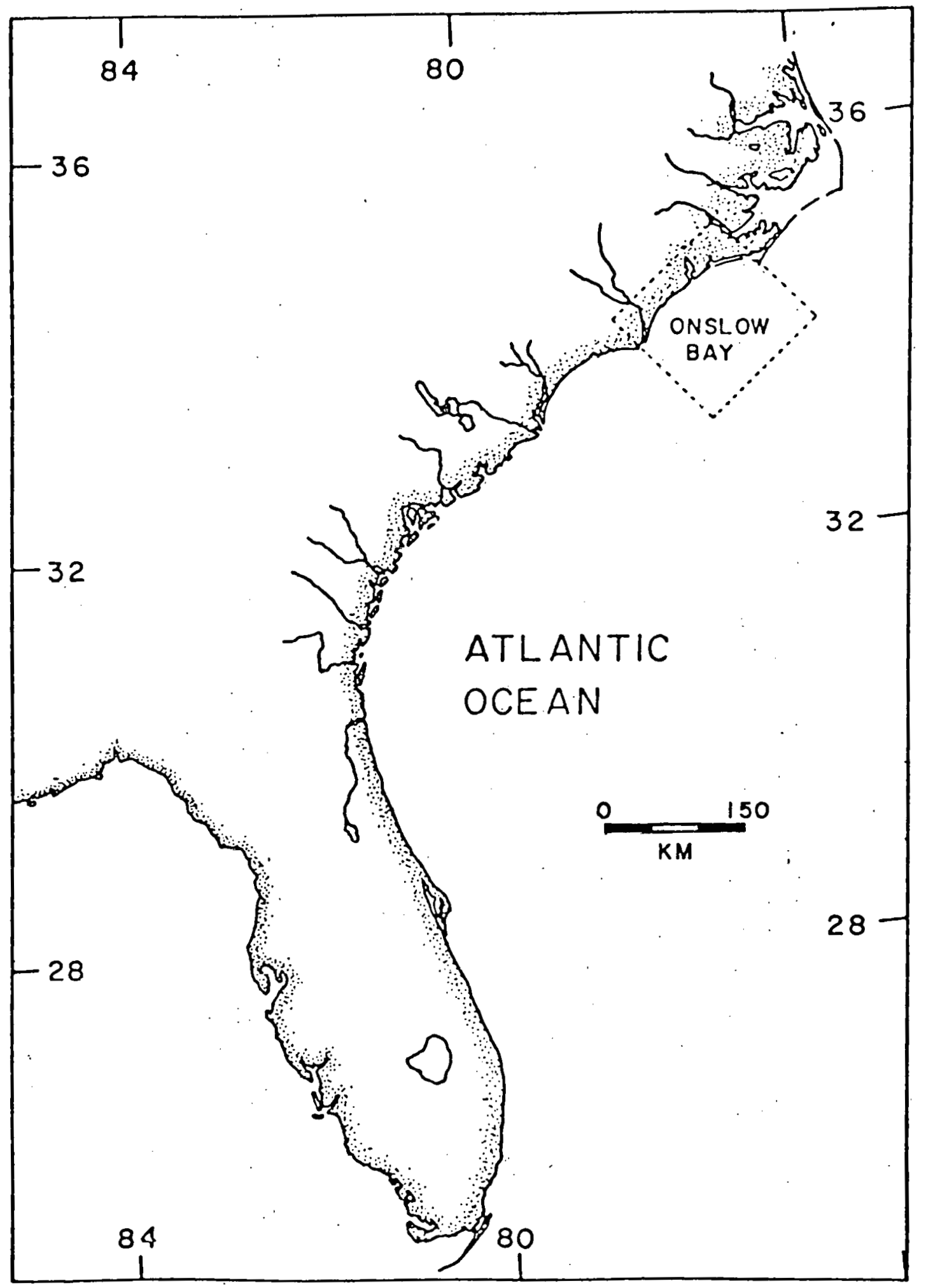

Figure 2. South Atlantic Bight 
In order to study the physics and biology of Onslow Bay, an intensive field study was undertaken as a joint venture by North Carolina State University and Skidaway Institute of Oceanography. Skidaway Institute of Oceanography has been responsible for the collection and analysis of the biological and chemical aspects of the field work. North Carolina State University has been concerned with the deployment and retrieval of current metcrs and analysis of the data collected with the meters.

The field program began in August of 1975 with the OBIS I (Onslow Bay Intrusion Study) cruise aboard the R. V. ADVANCE II. This cruise was primarily for the deployment of current meters in Onslow Bay; however, hydrographic data were collected from several stations. A second cruise (OBIS II) aboard the R. V. EASTWARD took place in September 1975. 'this cruise consisted of intensive hydrographic and biuluyical sampling during several intrusion cycles. Subsequent cruises (OBIS III and OBIS IV) have occurred in October and December of 1975 and have been concerned with deployment and retrieval of current meters with the collection of hydrographic data from some stations.

The most intensive study took place the summer of 1976 when Skidaway Institute of Oceanography undertook a six-week study of intrusions in Onslow Bay. The biological and hydrographic sampling was carried out in a scries of cruises aboard the R. V. BLUE FIN. The author participated in collection and analysis of data from the OBIS I and II cruises and 
the 1976 summer program. A similar program is planned for the summer of 1977 off the coasts of Georgia and Florida.

The results of this field program have been used to formulate the model presented in this paper and to verify its results. 
CHAPTER IV

INTRUSION PROCESS

Intrusions are an interesting and intriguing phenomenon associated with the Gulf Stream System. Although intrusions and other. phenomonological processes (meanders, eddies, etc.) have been the subject of a certain amount of study upstream from Cape Hatteras (Iselin and Fuglister, 1948; Fuglister, 1951; Ford et al, 1952; Ford and Mi1ler, 1952), 1ittle is known of their behavior between the Florida Straits and Cape Hatteras wherc the Gulf Stream flows close to shore over the Blake P1ateau. More recent studies (Webster, 1961; Blanton, 1971; Stefansson et al., 1971; Pietrafesa et al., 1975) have focused on the intrusions occurring in Onslow and Raleigh Bays.

An intrusion may be the result of variations or meanders in the axia1 position of the Gulf Stream off Onslow Bay (von Arx et al., 1955; Webster, 1961). This movement causes an alternating onshore and offshore surface motion, the dominant amplitudes of which are about $10 \mathrm{~km}$. with periods on the order of one week (Webster, 1961). These meanders, a type of skewed wave motion, typically consist of a confused slow onshore flow persisting four-to-seven days followed by an intense oftshore motion lasting one-to-four days (Blanton, 1971). The intrusion may also be compensational and wind-forced in nature. Mechanical forcing by seasonally persistent southwesterly winds associated with the summer northward migration of the Azores-Bermuda High may sinply drive the surface waters seaward requiring a compensatory onshore flow at depth.

The distribution of temperature and salinity on and adjacent to the continental shelf, both horizontal and vertical, appear to verify the 
onshore-offshore motion of the Gulf Stream in Onslow and Raleigh Bays (Bumpus, 1955; Bumpus and Pierce, 1955; Webster, 1961; Stefansson et al., 1971; Atkinson et al., $1976^{1}$ ).

Webster (1961) found cold fresh tongues of water on the inshore side of the Gulf Stream axis which appeared to have an upstream source on the continental shelf and had been entrained into the inshore edge of the Gulf Stream. The occurrence of shelf water along the inshore edge of the Stream may be explained in a similar way (Bumpus, 1955). An intrusion of the Gulf Stream by means of onshore flow along the bottom could displace a similar volume of shelf water and force it offshore at the surface. This water would then be entrained by the Gulf Stream. There are documented occurrences of intrusions along the bottom (Bumpus, 1955; Bumpus and Pierce, 1955; Stefansson et al., 1971; Atkinson et a1., $1976^{2}$; Pietrafesa et a‥, 1975).

As suggested previously, winds and local accelerations of the Gulf Stream are also "intrusion" generating phenomena. Southerly to southwesterly winds may deflect the surface waters offshore where they are entrained into the Gulf Stream (Bumpus, 1955; Stefansson et a1., 1971; Pietrafesa et al., 1975). The divergence of surface coastal waters created by frequent southwest winds may cause bottom intrusions of Gulf Stream water onto the continental shelf (Blanton, 1971). The intrusions resulting from this upwelling-1ike process are thus probably compensatory

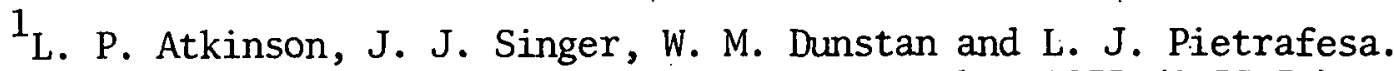
Hydrography of Onslow Bay, North Carolina: September 1975 (OBIS II), (unpublished manuscript). Savannah, Georgia: Skidaway Institute of Oceanography, March 1976.

'See footnotè 1 . 
in nature (Pietrafesa and Atkinson, 1976). Meterological data presented by Ruzecki (1974) show that the dominant winds during summer months when intrusions are prevalent, come from the south to southwest (Figure 3). Accelerations of the Gulf Stream adjacent to the Onslow Bay shelf break may cause an upward migration of isopycnals on the inshore side of the Gulf Stream axis. These isopycnals could then extend onto the shelf and appear as an apparent intrusion.

The dominant periods of the Gulf Stream position variations do have occasional correspondence with periods of offshore winds, but to date, no direct physical connection has been determined. Lunar tidal components, either monthly or diurnal, have amplitudes which are at most, small in comparison with those of the principle meanders (Webster, 1961). At present, there is no satisfactory means of separating the effects of southwest winds, meanders and accelerations as causes of intrusions of Gulf Stream water onto the continental shelf.

Blanton (1971) proposed the following descriptive model for the intrusion process. During summer conditions, when the shelf: water is stratified, intrusions of Gulf Stream water occur along the bottom. This water comes from the continental slope below the shelf break and lowers the water temperature near the bottom. Under these conditions, the bottom velocity has a net onshore component. The colder, more saline water moving over the shelf break forms a strong pycnocline at the bottom. Once enough water has been forced onto the shelf and the intrusion has begun to weaken, the pycnocline is found approximately 10-15 meters above the bottom, thus separating Gulf Stream water from shelf water. 

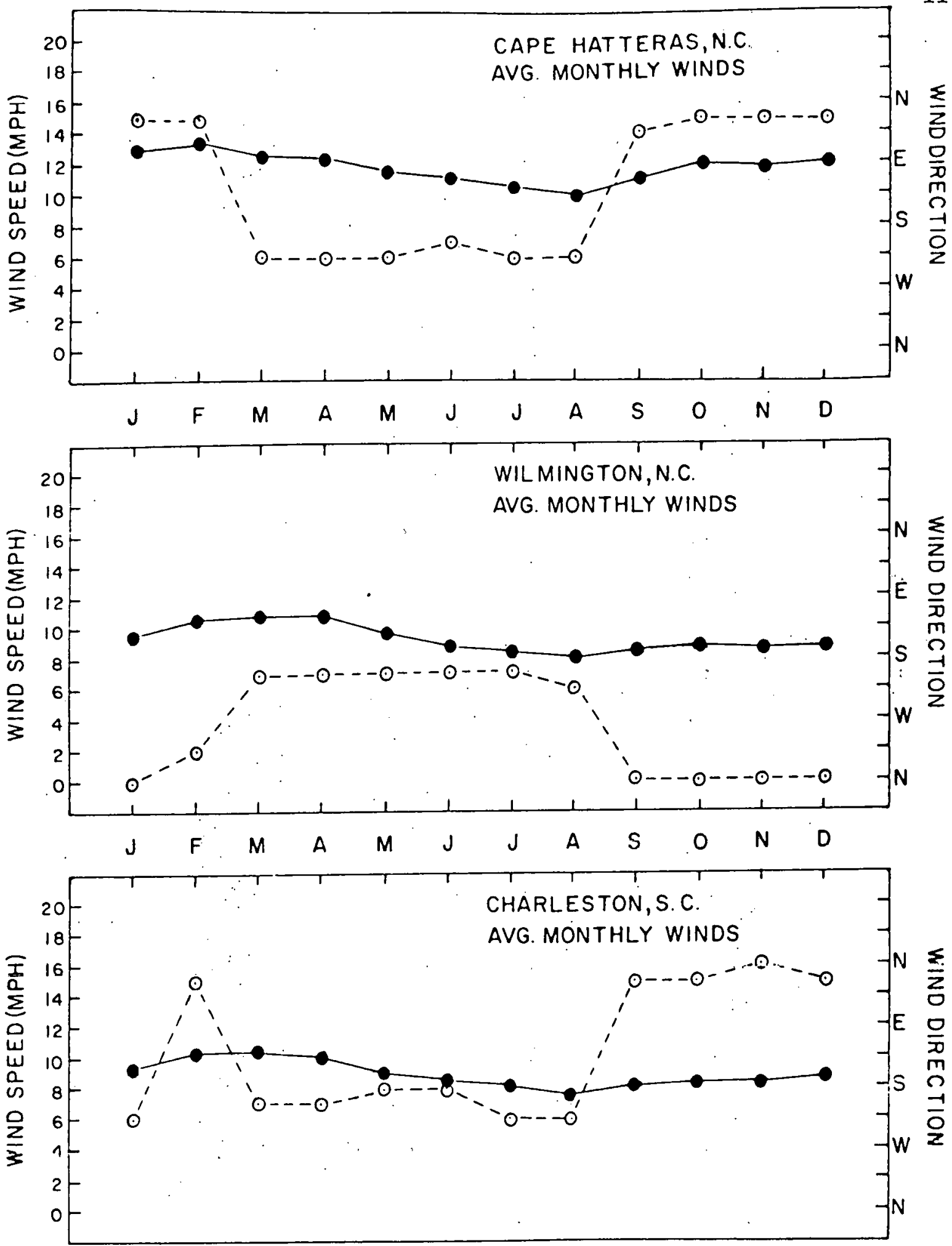

Figure 3. Average monthly wind speed (-) and direction $(0-0)$ for land stations from Cape Hatteras to Cape Canaveral 
Mixing then weakens the pycnocline and Gulf Stream water is mixed upward into the surface layer. This process is shown in Figure 4.

During winter months the dynamic conditions of the shelf are much different. The shelf water is much denser and it is possible that water from below the continental slope would not have sufficient energy to displace the denser shelf water. Evidence of intrusions during winter months has been observed (Bumpus, 1955; Stefansson et a1., 1971; Atkinson et a1. $1976^{3}$ ).

Ficld studios (Stefansson et 1 l. , 1971; Pitrarasa et al., 1975) verify the role of onshore-offshore movements of the inshure edge of the Gulf Stream in bringing about exchange of its water with continental shelf water. Near bottom currents in Onslow Bay (Blanton, 1971; Pietrafesa et al., 1975) seem to support the intrusion mechanism first described by Bumpus in 1955 .

Figures 6 through 10 are progressive vector diagrams of data co1lected (Pietrafesa et al., 1975) from current motcrs deployed in Onslow Bay (Figure 5) from August 6, 1975 to September 26, 1975 and October 14, 1975 to December 9,1975 . One can readily see the onshore movement of surface waters. Hydrographic data (Figures 12, 13, 15, 16 and 18) collected on the R. C. AUVANCE II (August, Octuber and December of 1975) and the R. V. EASTWARD (September of 1975) show the occurrerice of intrusions which is in agreement with current meter data. The low temperatures

3. P. Atkinson, J. J. Singer and L. J. Pietrafesa. Onslow Bay Intrusion Study Hydrographic Observations During Current Meter Servicing Cruises in August, October and December 1975--OBIS I, III and IV, (unpublished manuscript). Savannah, Georgia: Skidaway Institute of Oceanography, June, 1976. 


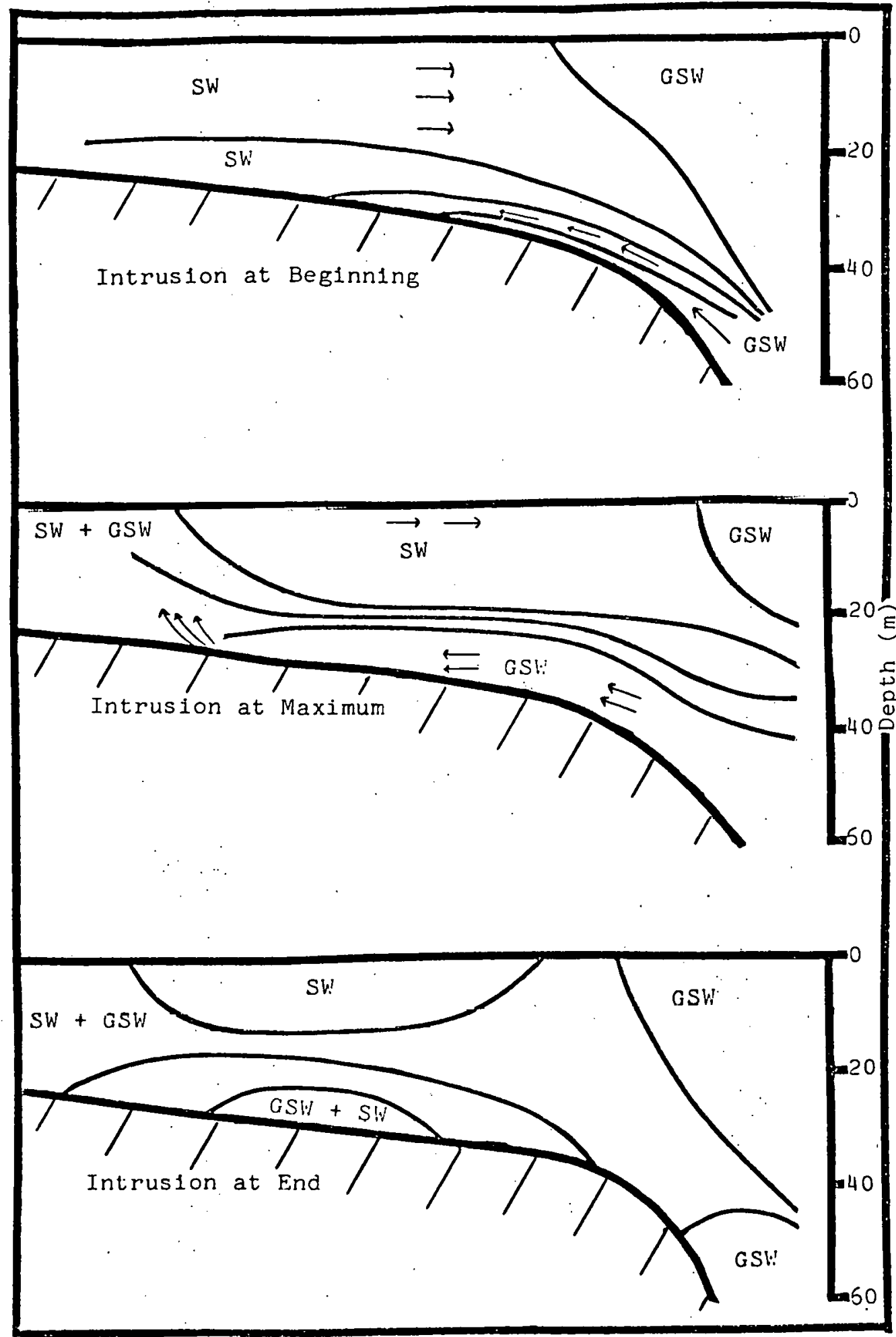

Figure 4. Schematic diagram showing intrusion as described by Blanton (1971) 


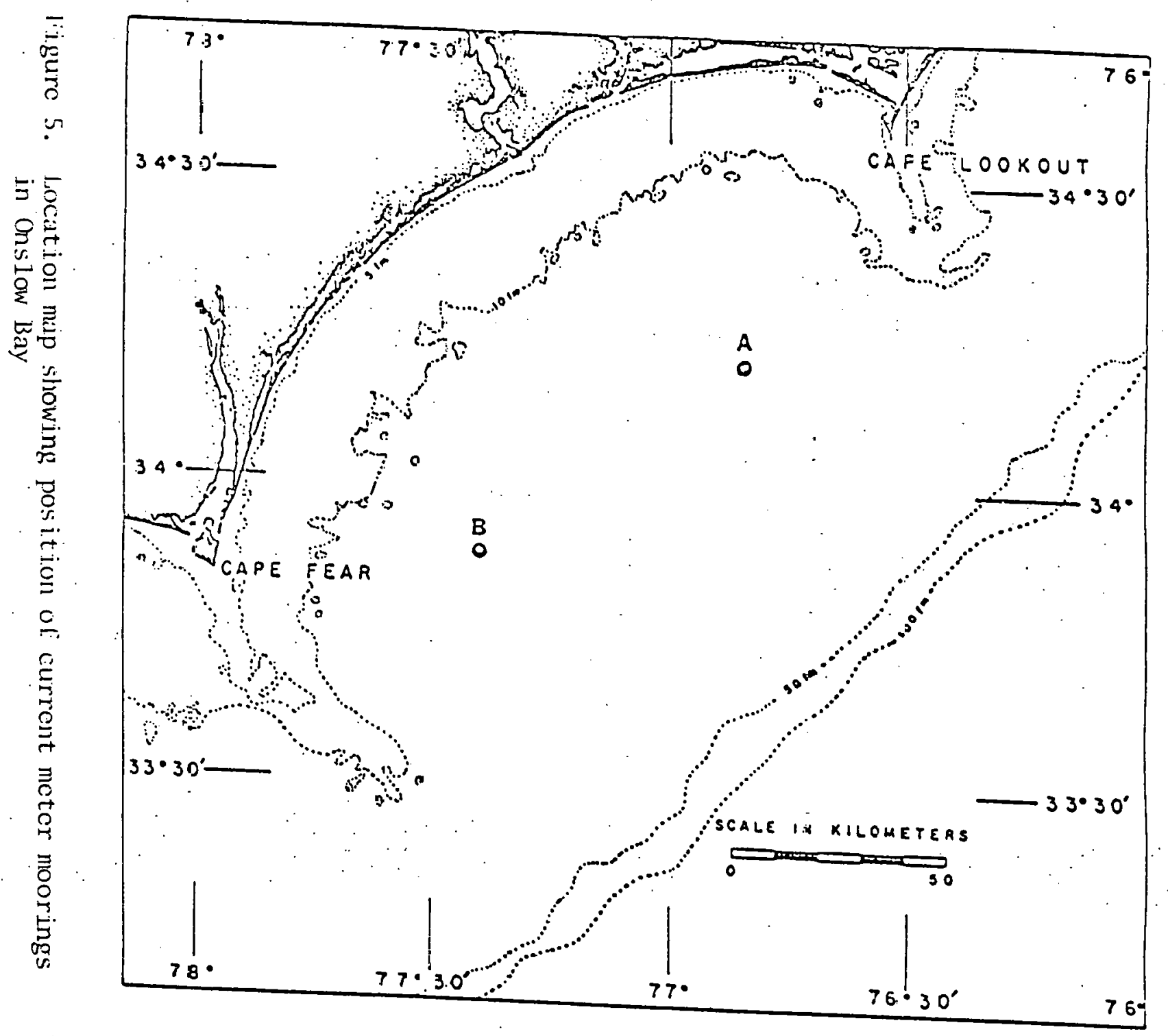




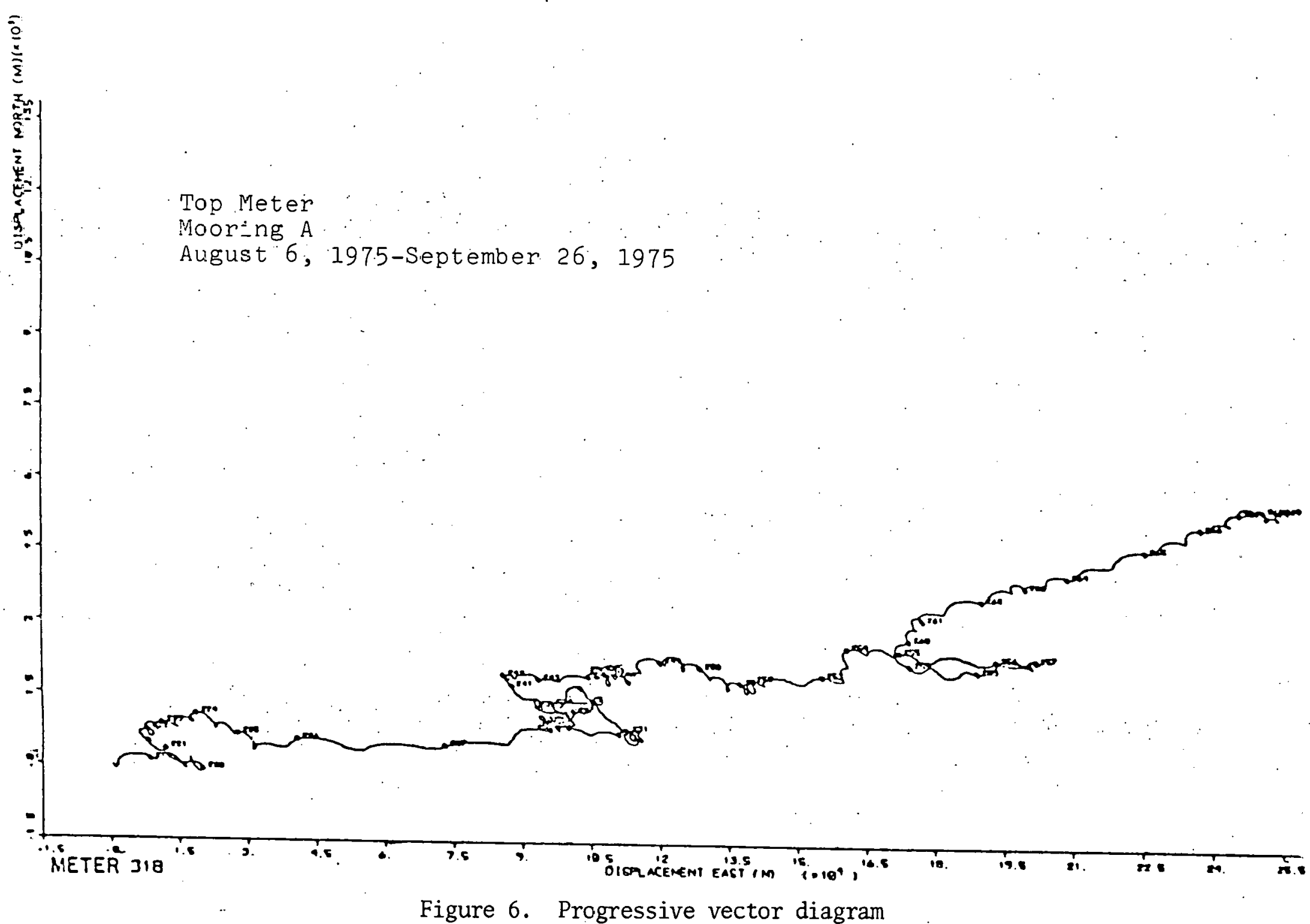

Figure 6. Progressive vector diagram 


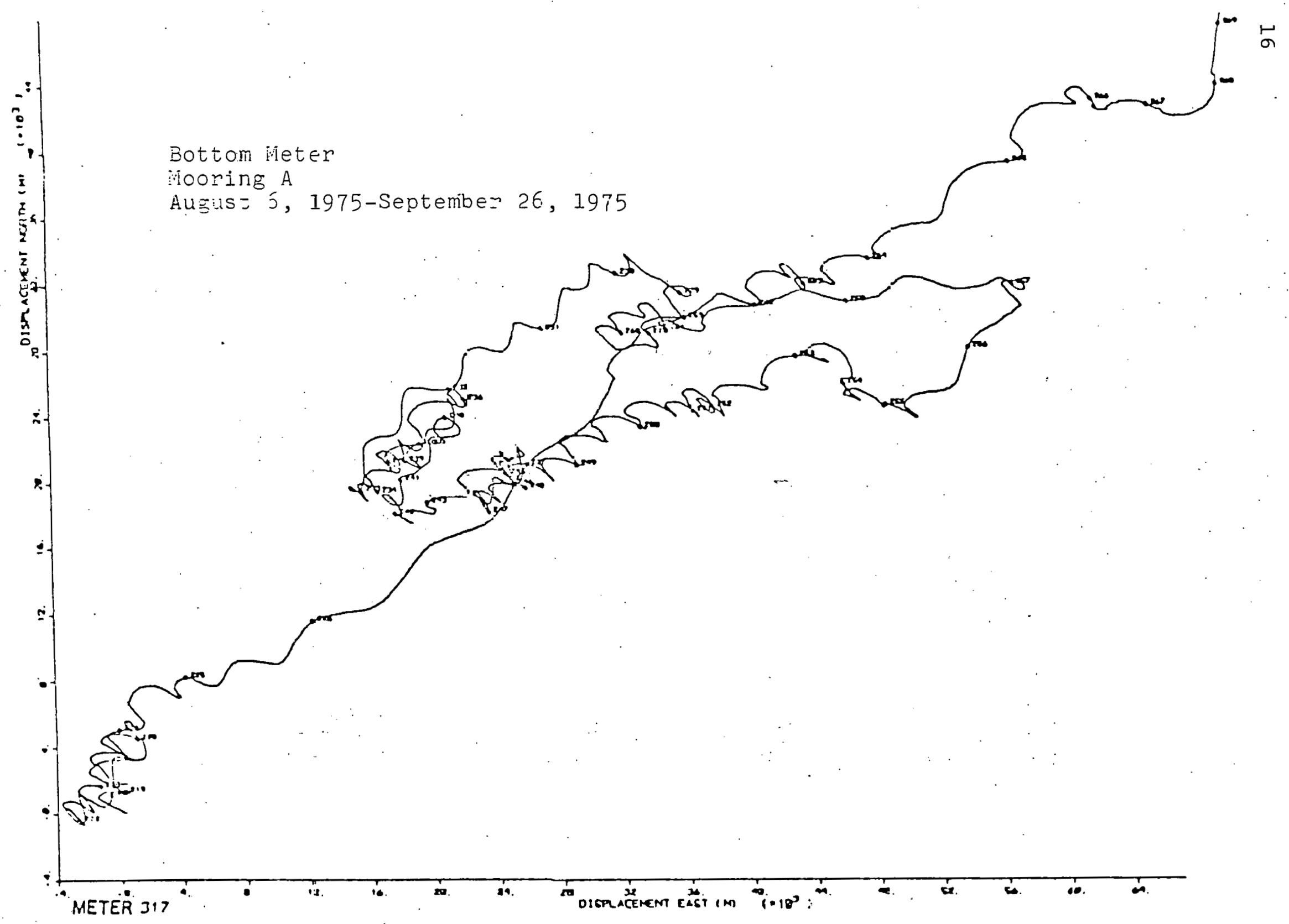

Figure 7. Frogressive vector diagram 


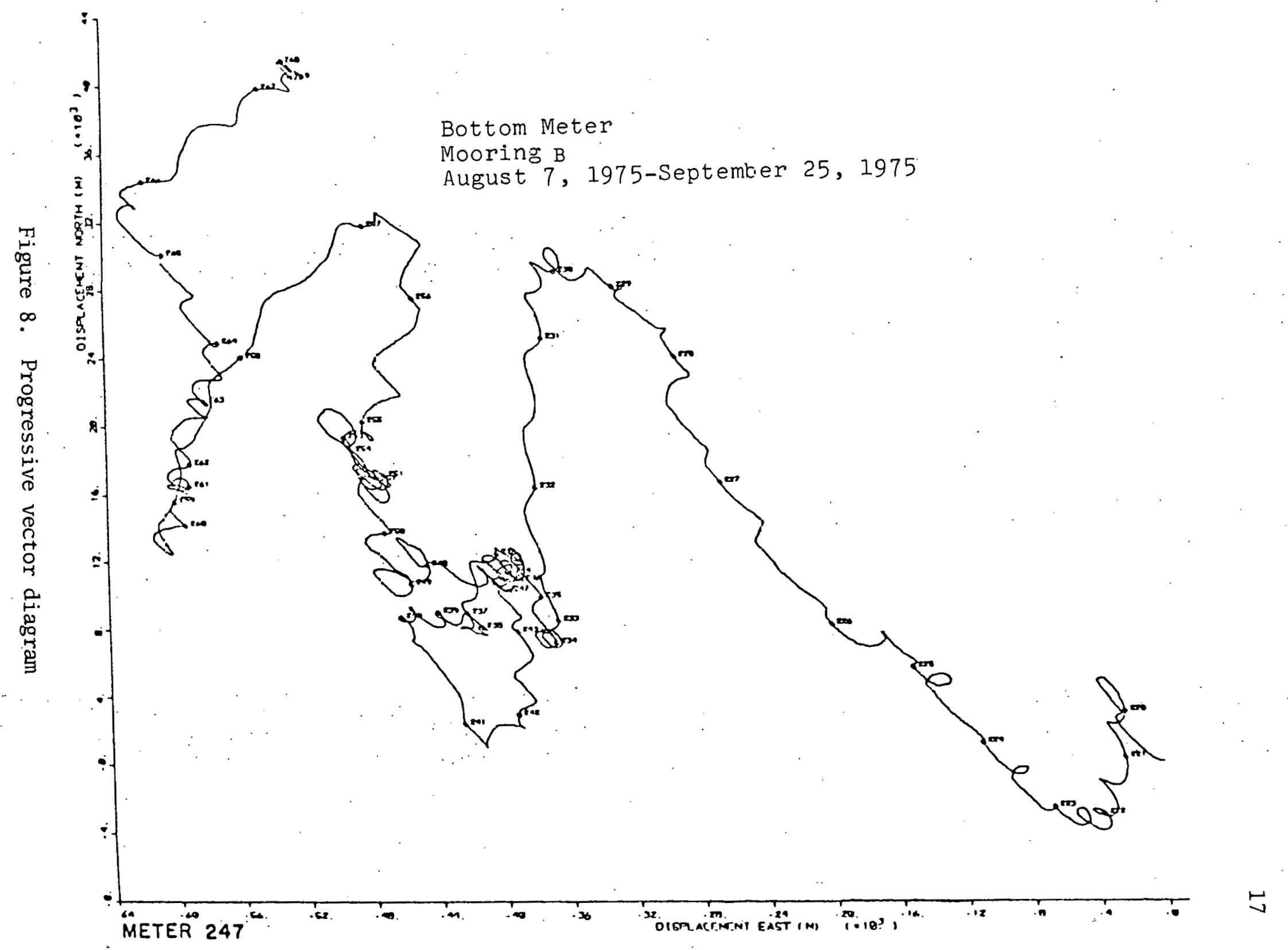




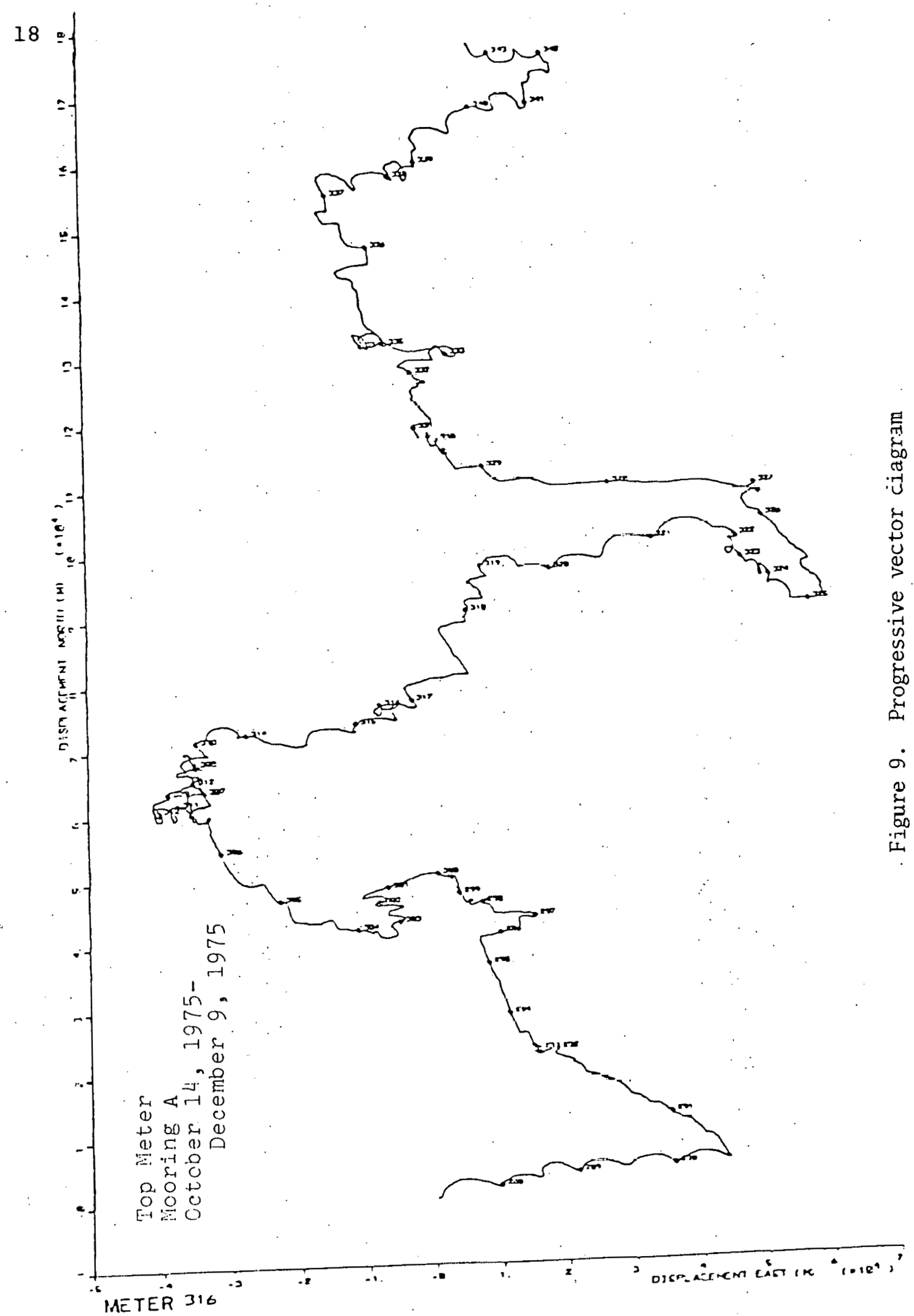




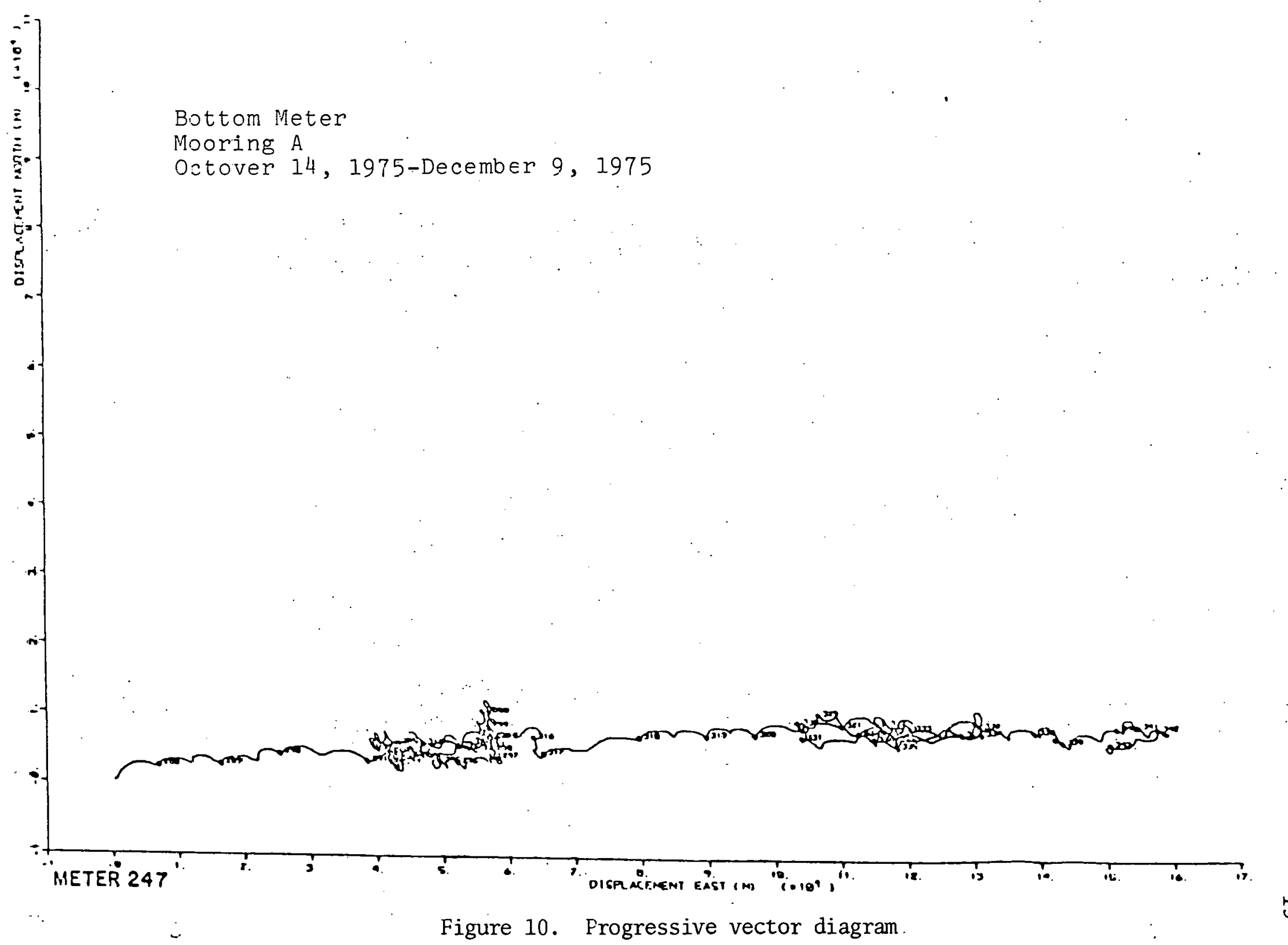




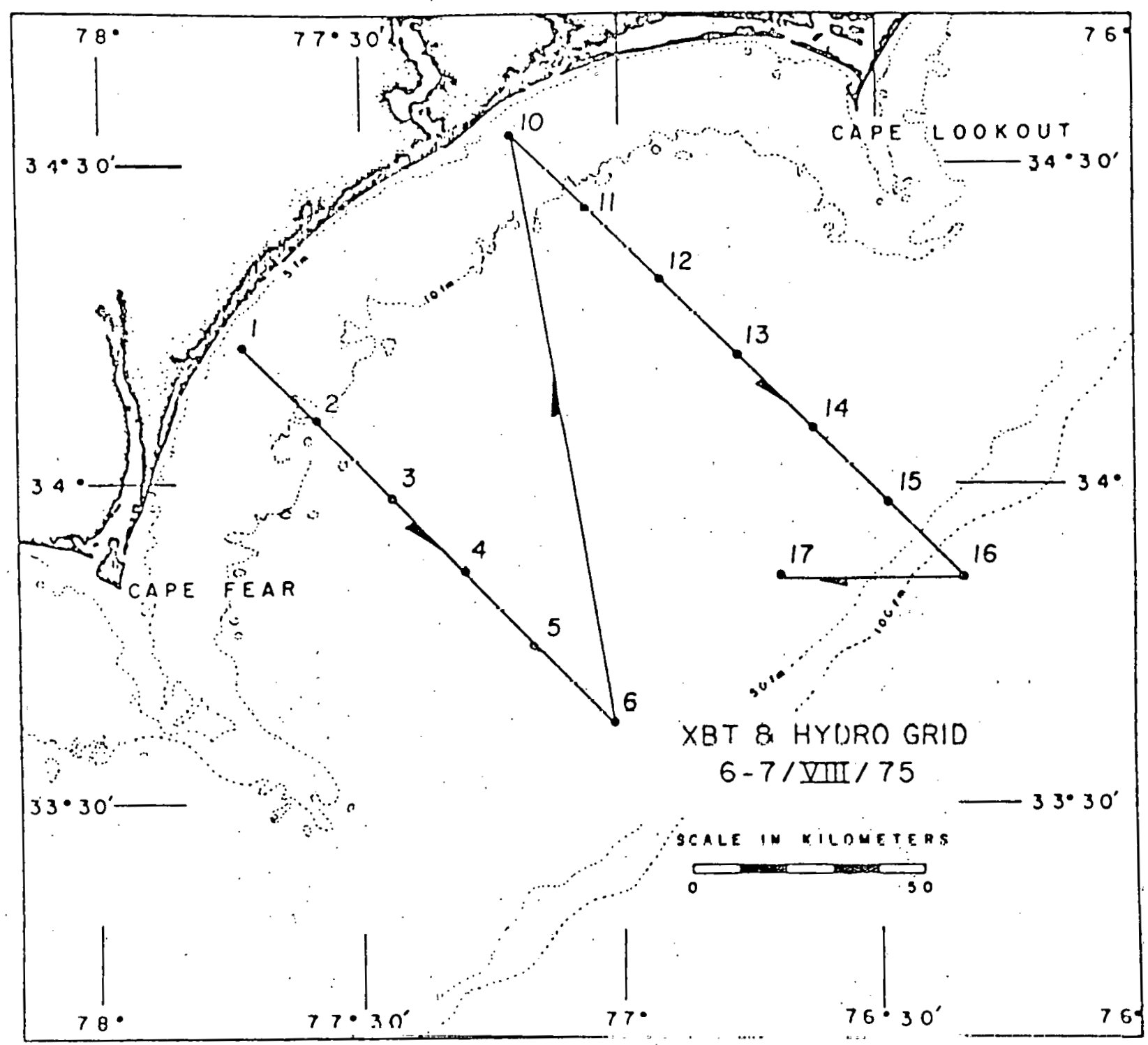

ligure 11: Cruise track, OBIS I: $6-7$ ^ugust 1975 

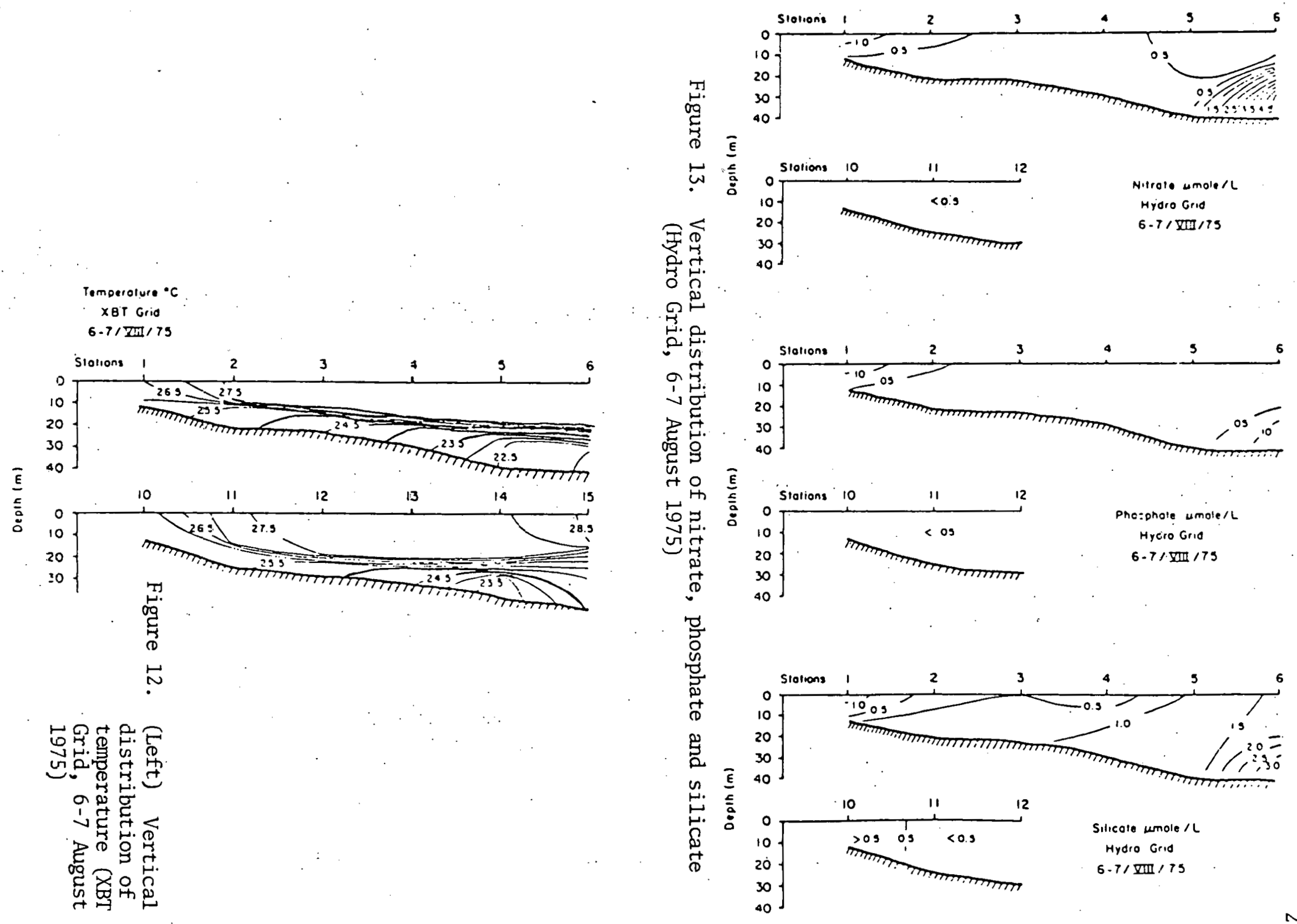


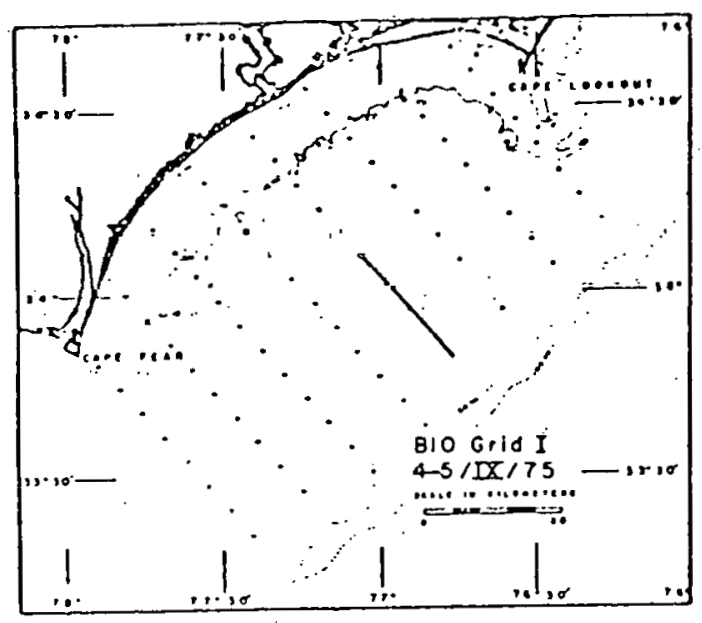

(a)

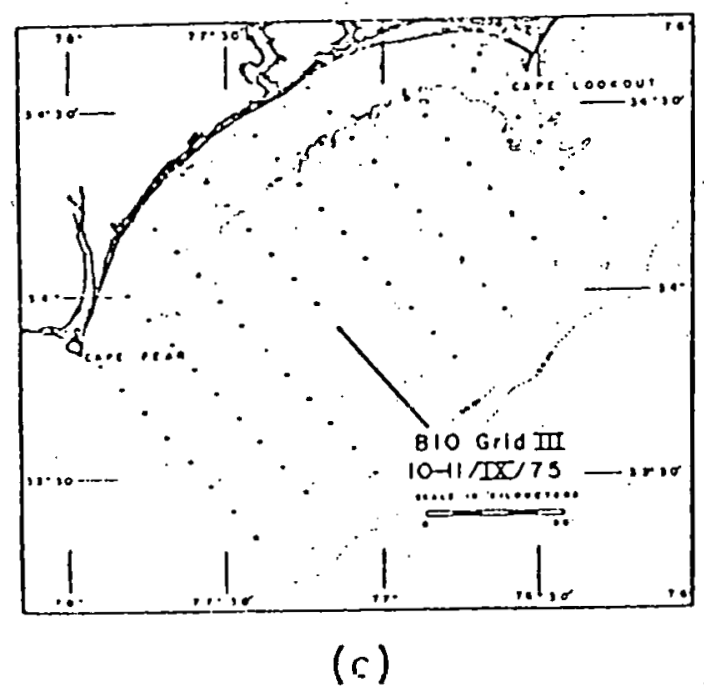

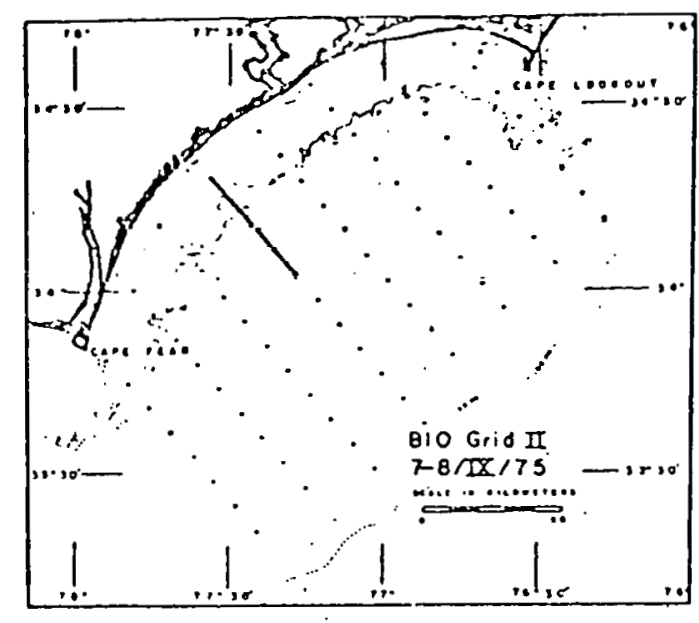

(b)

Figure 14. Bio Grid cruise tracts--OBIS II 
Temperalure ${ }^{\circ} \mathrm{C}$

Bio Grid II

7-8/IX/75

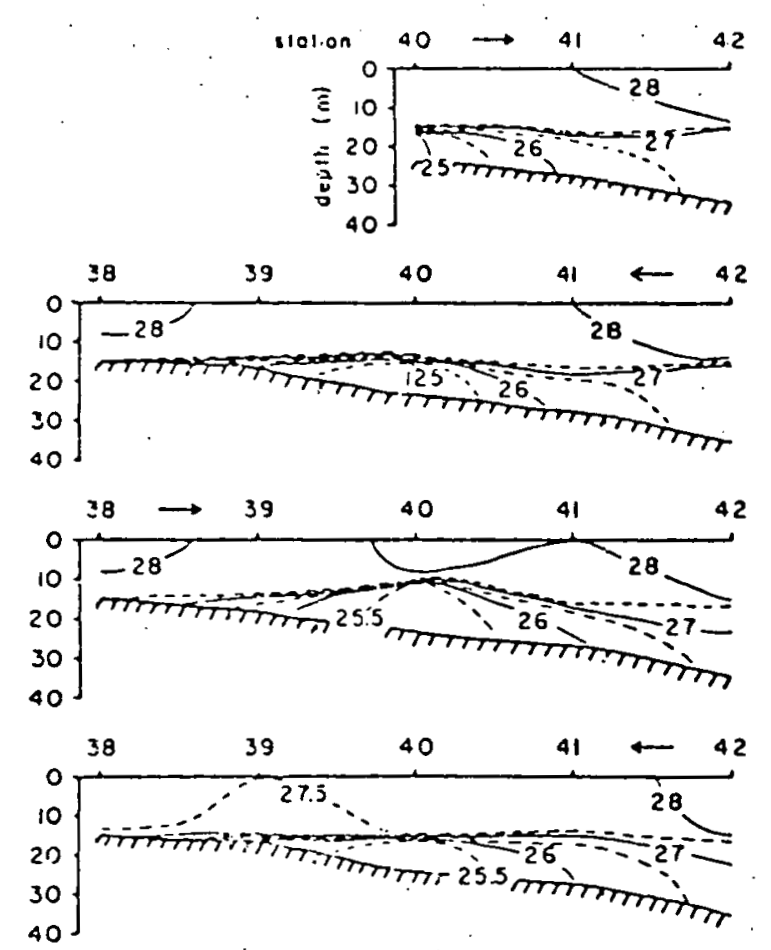

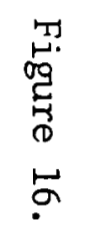

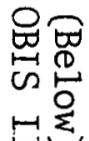

幽

政.

寻 尺

a

of

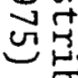

芦.

9

웅

?

용

葛

$\stackrel{\stackrel{0}{\rightleftarrows}}{\rightleftarrows}$

o

画

疍

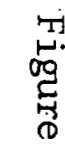

礼

ç

罡芒

吕

요.

或.

ज्ञ

ज氮

莺

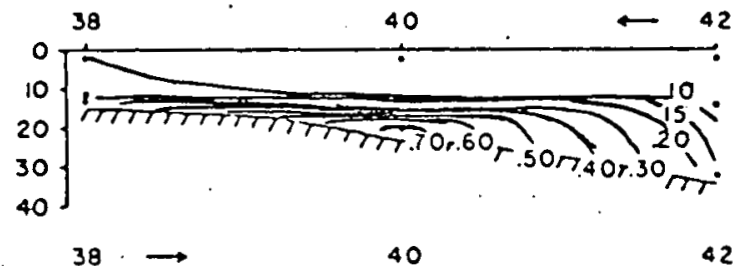

Bio Grid II

$7-8 / \operatorname{Ix} / 75$

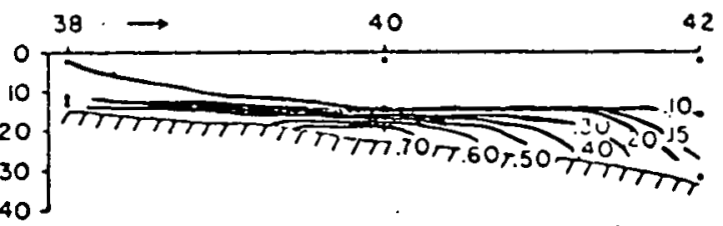

思

10

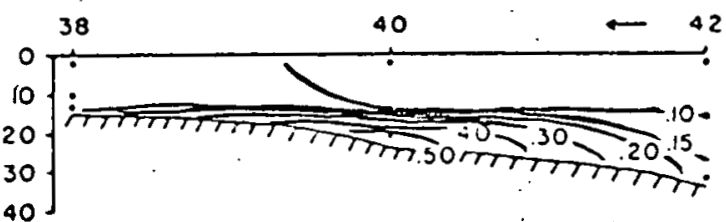




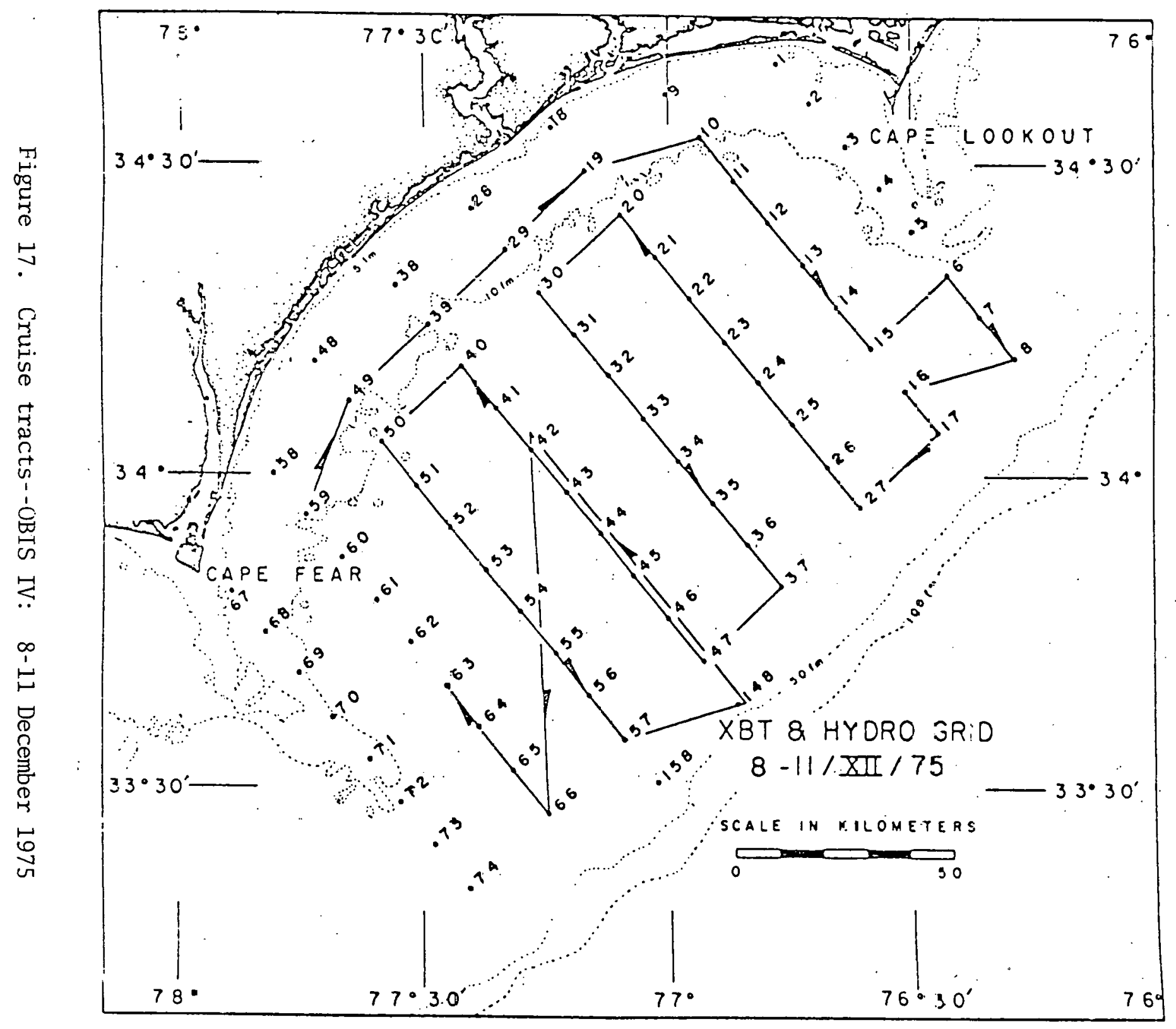




\footnotetext{
Temperolure " $\mathrm{C}$

xai a hydo Grio

$8.10 / \times 11 / 75$
}
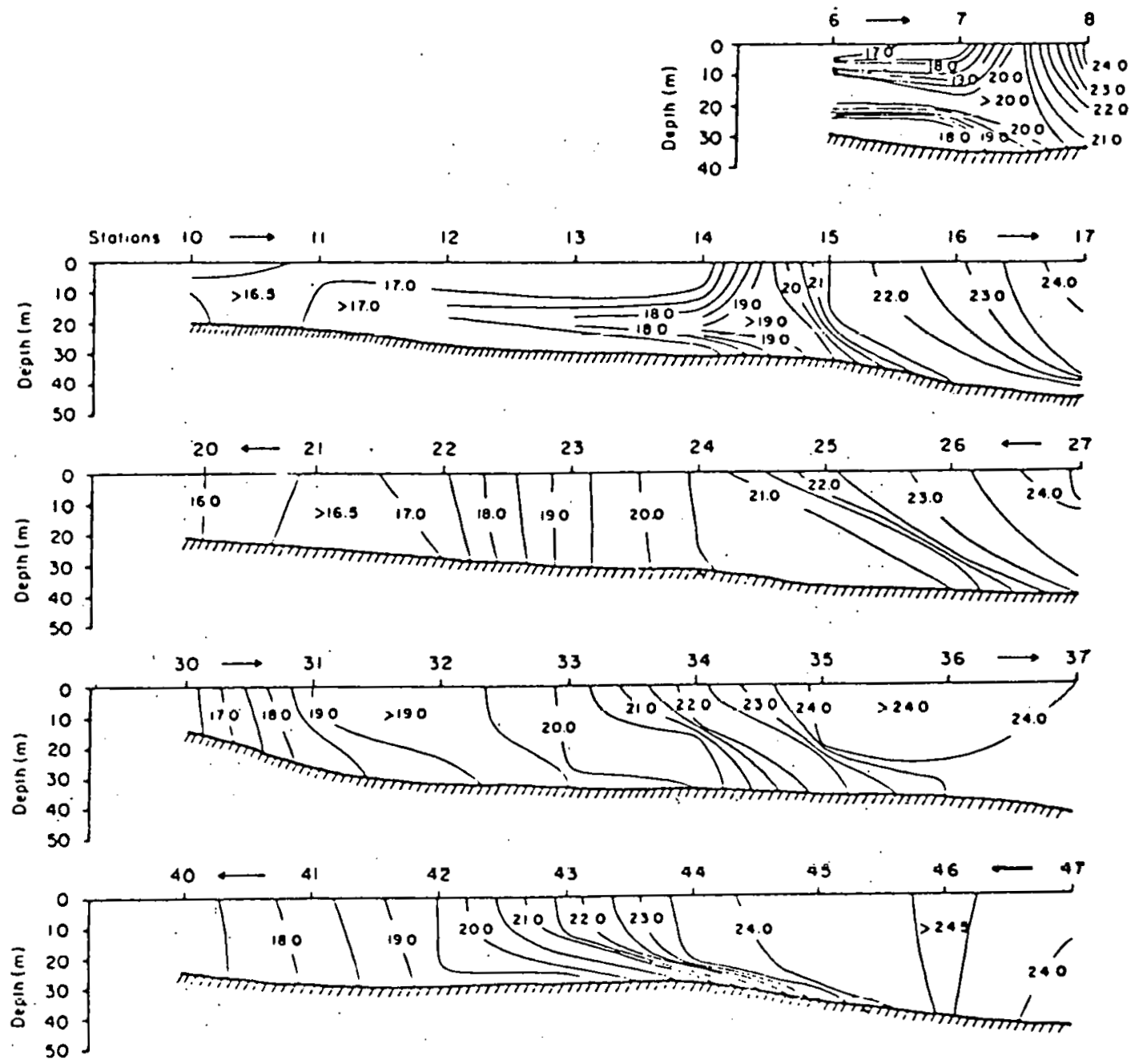

Figure 18. Vertical distribution of temperatures (XBT and Hydro Grids, 8-10 December 1975) 
and high nutrient values shown in the vertical and horizontal profiles are characteristic of intruded waters. Also, the increase in chlorophyll a values indicates greater phytoplankton productivity which is due to the increased nitrate concentration. Figures 11,14 and 17 indicate the cruise tracts and station positions from which the data were collected. Previous studies have not dealt specifically with the effects of intrusions on shelf waters since a comnon belicf appears to be llat intrusions are present only at the shelf break and do not extend shoreward of the outer one-third of the shelf. However, it has been observed by Atkinson et al. 4 that intrusions quite often reach the nearshore zone (5-10 km. from the beach). Present data (Stefansson et al., 1971; Blanton, 1971; Atkinson et al. ${ }^{5}$ ) indicate that, during their existence, intrusions. are a dominant factor controlling primary productivity in the South Atlantic Bight.

${ }^{4}$ See footnote 1

${ }^{5}$ See footnote 1 . 
CHAPTER V

SYSTEM REPRESENTATION

In this model it is assumed that the nitrate distribution is governed by

$$
\frac{d N}{d t}=\frac{\partial N}{\partial t}+u \frac{\partial N}{\partial x}+w \frac{\partial N}{\partial z}-\frac{\partial}{\partial x}\left[D_{x} \frac{\partial N}{\partial x}\right]-\frac{\partial}{\partial z}\left[D_{z} \frac{\partial N}{\partial z}\right]=\text { biol. terms }
$$

The first three terms on the left-hand side of the equation represent collectively the change of nitrate following a water parcel moving about in the ocean. The first term is the local change and the two other terms are the advective changes. The last two terms on the left-hand side represent eddy diffusion, where $\mathrm{D}_{x}$ and $\mathrm{D}_{z}$ are the horizontal and vertical eddy diffusion coefficients, respectively.

The biological terms include any biotic process that serves as a source or sink of nitrate in the system. An equation similar to Equation (1) can be written to describe the biological processes.

$$
\begin{aligned}
\frac{\mathrm{dN}}{\mathrm{d} t}= & \text { loss from uptake by phytoplankton + extracellular release by } \\
& \text { phytoplankton + excretion by zooplankton and fish + input } \\
& \text { from decomposition by detritus + nitrogen fixation by Blue } \\
& \text { Greens + regeneration of nitrate from sediments }
\end{aligned}
$$

Each term is discussed separately and its relative importance determined. Figure 19 summarizes the dynamics of the biological system. 


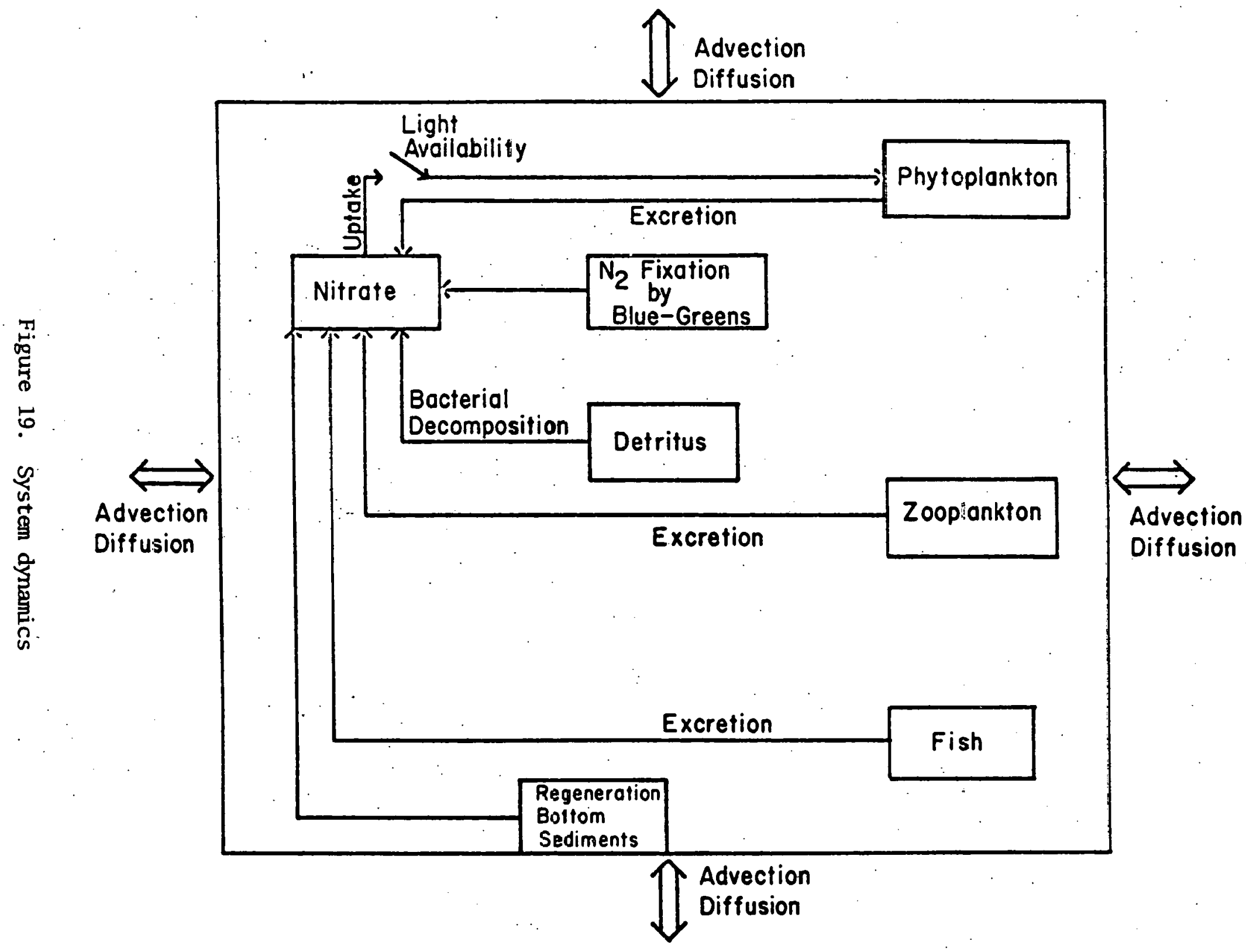


Uptake Term

A fundamental assumption of this model is that phytoplankton nutrient uptake obeys Michaelis-Menton kinetics. Dugdale (1967) demonstrated the applicability of Michaelis-Menton kinetics to phytoplankton uptake. Subsequent laboratory and field work (Eppley and Coatsworth, 1968; Thomas and Dodson, 1968; MacIssac and Dugdale, 1969; Eppley, Rogers and McCarthy, 1969; MacIssac and Dugdale, 1971) support the hypothesis that uptake rates of nitrate, phosphate and ammonium are hyperbolic functions of concentration.

The Michaelis-Menton formalization of Monod (1942) kinetics is given by

$$
V=\frac{V_{m}^{\prime} N}{(K+N)}
$$

where $V$ is the uptake rate of nutrient $N, V_{m}$ is the maximum uptake rate that can be obtained by elevating the nutrient concentration and $K$ is the Michaelis constant or half saturation constant. $K$ is the substrate concentration permitting a half-maximal velocity. These two quantities, $\mathrm{K}$ and $\mathrm{V}_{\mathrm{m}}$, are characteristic for a given uptake reaction under a given set of conditions. If these two quantities are known, it is then possible to calculate the rate of the reaction for the full range within which the Michaelis-Menton equation applies.

Lehman et al. (1975) use a variation of the Michaelis-Menton equation for determining nutrient uptake rates. This is given by

$$
V=\frac{\left[\left(Q_{m}-Q\right) /\left(Q_{m}-K_{q}\right)\right] v_{m} s}{(K S+S)}
$$


where $Q=$ the quantity or quota of nutrient concentration per cell, $\mathrm{K}_{\mathrm{q}}=$ the minimum cell nutrient content below which cell division cannot proceed, and $Q_{m}=$ the maximum nutrient storage capacity of the cell. The function includes a feedback factor to account for end-product inhibition of uptake by nutrients that accumulate in the cells. The model presented in this paper does not consider the nutrients' molecular form within the cell. This allows one to ignore the nutrient pool. phenomenon. Once the cell has taken up the nutrient, it can be considered as belonging to the phytoplankton, whether it is immediately fixed into the biomass or stored for later anabolism.

Uptake rates can be significantly modified by temperature, light and ambient nutrient concentrations (MacIssac and Dugdale, 1971; Lassister, 1975). MacIssac and Dugdale (1971) found that in eutrophic waters, at high ambient concentrations the profile of nitrate and ammonia uptake may be controlled by light. The same is true for oligotrophic waters, but with the additional complication of low ambient nutrient concentrations.

Comparisons between oligotrophic and eutrophic regions of the rates of uptake of nitrate and ammonium integrated through the euphotic zone show that ammonium is the more important of the two sources in oligotrophic waters, while in eutrophic waters less than half of the nitrogen taken up is ammonia (MacIssac and Dugdale, 1971).

Eppley, Coatsworth and Solorzano (1969) have found that nitrate assimilation is associated with the production, within the ceils, of the enzyme nitrate reductase. Certain marine phytoplankton contain this enzyme when growing on nitrate, but only low levels of the enzyme 
have been found during growth with ammonium or when the nitrogen source was depleted. This suggests that the discrimination between nitrate and ammonium as nitrogen sources results from the repression of the nitrate reductase enzyme at high levels of ammonia. In the sea, ammonia concentrations are normally so low that this repression should not occur, and Eppley, Coatsworth and Solorzano (1969) were able to detect nitrate reductase activity in water collected from the tropical Pacific. In intruded waters, the concentrations of nitrate are high and those of ammonia low. Therefore, nitrate rather than ammonia is the more important nitrogen source.

The value used for an uptake velocity in this model is $1.2 \times 10^{-2}$ $\mu \mathrm{g}-\mathrm{at} / \mathrm{cell}$-hour which is the maximum uptake velocity determined for Ditylum brightwellii (Eppley and Coatsworth, 1968). This value was chosen because Ditylum brightwellii is similar in size to Rhizosolenia alata, which field studies have shown to be the most abundant phytoplankton during an intrusion. ${ }^{6}$ This value was multiplied by $1.93 \times 1.0^{5}$ cells (Rhizosolenia)/1iter to give an uptake velocity of $6.43 \times 10^{-5}$ $\mu \mathrm{g}$-at $\mathrm{NO}_{3} / 1-\sec .^{7}$

\section{Extracellular Release by Phytoplankton}

Extracellular products, which may be defined as soluble organic substances liberated from healthy, as distinct from injured or decomposing, cells are produced in algae in great variety and amount (Fogg, 1966). According to Fogg (1966) and Thomas (1971), a large proportion

6. M. Dunstan, Productivity in the South Atlantic Bight, Seminar, North Carolina State University, Raleigh, March 1976.

${ }^{7}$ W. M. Dunstan, personal communication, March 1975. 
of the products of phytoplankton photosynthesis is liberated in this way so that extracelluiar products could be of considerable importance as a source of energy in aquatic environments. Williams and Yentsch (1976) have found that the extent of extracellular phytoplankton production ranges from undetectable to 23 percent, averaging 6.9 percent.

Magnitudes published for excretion are controversial due to experimental difficulties, but studies indicate that a significant portion of compounds excreted may be in the form of amino acids (Fogg, 1966; Williams and Yentsch, 1976).

Williams and Yentsch (1976) measured the chemical characteristics of the water column in which their excretion experiments were carried out. Their results are shown in Table 1. The extremely low levels of nitrite and nitrate are readily apparent.

Table 1. Chemical characteristics of water ${ }^{a}$

\begin{tabular}{lc}
\hline Constituent & Typical range \\
\hline & $\left(\mu g-\text { at } 1^{-1}\right)^{\prime}$ \\
Phosphate & $0.15-0.20$ \\
Total phosphorus & $0.20-0.25$ \\
Nitrate & $0.0-0.10$ \\
Nitrite & $0.10-0.20$ \\
Total nitrogen & $5.5-4.5$ \\
\hline
\end{tabular}

QValues from P. J. LeB. Williams and C. S. Yentsch, Marine Biology, Vol. $35,19 \%, \mathrm{pp} .31-40$.

Using these values for nitrate and a time scale for loss of the absorbed nutrient of 40 hours (O'Brien and Wrobleski, 1973), one arrives at a value on the order of $10^{-7} \mu \mathrm{g}-$ at $\mathrm{NO}_{3} / 1-\mathrm{sec}$ for extracellular release of phytoplankton. 
Zooplankton Excretion

Zooplankton excretion is an important part of marine ecosystem models since excretion is a mechanism by which nutrients are recycled into the water column (Cushing, 1969). Harris and Riley (1956) found that body nitrogen in zooplankton from Long Island Sound accounted for, on an average, 8.91 percent of dry weight. Animals studied by Harris (1959) excreted the equivalent of 48 percent of their body nitrogen daily. These measurements were made during spring when a significant amount of particulate material was present in sea water and available to the animals during the excretion experiments. More recent studies (Corner and Newe11, 1967) have shown that most of the excreted nitrogen is in the form of ammonia which accounts for 60-100 percent of the total (average 74.3 percent) and some of the remainder may be lost as urea. There is no evidence for the excretion of measurable amounts of amino acids by copepods.

Data collected by Paffenhöfer on copepod species and density in Georgia coastal waters indicate seasonal variation in the copepod populations, the most abundant population being present during May. Using these values (no. animals/liter seawater), and the ash free weights for the various copepod species, values ranging from $20-120 \mu \mathrm{g}$ ash free wt./ liter are obtained. Corner and Newell (1967) have determined excretion rates for zooplankton populations in Plymouth Sound of 2-5 $\mu$ g atoms N/ $\mathrm{mg}$ dry body weight-day. If one assumes that approximately 1 percent of the nitrogen excreted is in the form of nitrate, a number for zooplankton excretion on the order of $10^{-8} \mu \mathrm{g}$-at $\mathrm{NO}_{3} / 1-\mathrm{sec}$ is obtained. 


\section{Excretion by Fish}

The nitrogenous material excreted by the animal body is of interest because it reveals the end products of protein metabolism within the animal. In the fish kingdom the excretion of marine teleosts has been studied extensively. (Smith, 1929; Wood, 1958; Brett and Zala, 1975) and recently mathematical descriptions of the relation between nitrogen excretion rates and protein consumption levels have been formulated (Savitz, 1971).

The un ilusy iltrogen of màrine teleosts constitutes only a small fraction of the total nitrogenous substances excreted by the fish. Approximately 6 to 10 times as much nitrogen is excreted by the gills as by the kidneys (Smith, 1929; Wood, 1958). The branchial excretion consists largely if not entirely of the readily diffusable substances, ammonia, urea, amine or amine oxide derivatives (Smith, 1958). The less diffusable substances such as creatine, creatinine and urir acid are excreted by the kidneys (Smith, 1958).

If nitrogenous excretion by fish is to be included, it necessitates the determination of a nitrate excretion rate for the region. This is done using values for fish production and population.

The fishing grounds of Onslow Bay have been described by Struhsaker (1969) who sampled 956 exploratory trawling stations in 11-183 meters of water on the continental shelf of the southeastern United States. His study showed that the shelf can be divided into five habitats: coastal, open shelf, live bottom, shelf edge and lower shelf, each with a distinct association of demersal fishes. For the purpose of this study, only the fish population of the open shelf, live bottom, shelf 
edge and lower shelf:will be considered. The coastal region is not included since it is considered to extend to approximately three miles offshore. However, it should be mentioned that this is the most productive fishing area, containing menhadden, shrimp, mullet and flounder, just to name a few.

According to Struhsaker (1969) the open shelf (18-54 m.) has poor potential for trawl fishing for food fishes. Sampling in this area yielded catches of only 100-600 pounds of fish per drag.

Live bottom habitats are small areas of broken relief and a rich sessile invertebrate fauna. These areas have the best food-fish potential for food utilization on the continental shelf. However, there are no extensive areas of this type in Onslow Bay.

Most fishing along the shelf edge and lower shelf is done by sports fishermen. No figures are available for pounds of fish taken by these fishermen and Strulisaker (1969) only gives a list of the most frequently caught species.

A nomal trawling path is approximately fifty feet wide. With the ship moving at a speed of 4-5 knots for approximately thirty minutes, a path length of nearly two miles is covered. Using this area, a depth of 18-35 meters and the above catch figures, a fish density on the order of $10^{-5}$ grams of fish/1iter is obtained.

Using data presented by Wood (1958), excretion rates of approximately $10^{-8} \mu \mathrm{g}$-at $\mathrm{N}_{2} / 1-\mathrm{sec}$ per fish can be calculated. If 1 percent of this is considered to be in the form of nitrate, an excretion rate for marine teleosts of $10^{-10} \mu \mathrm{g}$-at $\mathrm{NO}_{3} / 1-\mathrm{sec}$ per fish is calculated. When multiplied by the fish density calculated above, a number on the order of 
$10^{-15} \mu \mathrm{g}-\mathrm{at} \mathrm{NO}_{3} / 1-\mathrm{sec}$ is obtained. This number is extremely small and can be neglected since it will not contribute significantly to the nitrate concentration in Onslow Bay waters.

\section{Decomposition of Detritus}

The detrital fraction of the particulate matter in the sea contains no living plants or animals, but includes bacteria, the fecal pellets and cast molds of zooplankton and disintegrated phytoplankton cells (Corner and,Davies, 1971). Jorgensen (1966) has concluded that of the total particulate matter present in the sea, generally only 10-20 percent by weight is represented by phytoplankton. To date, the role detritus plays in the regeneration of nutrients in marine ecosystems is poorly understood and studied. However, it is recognized that detritus may be an important food source for zooplankton (Baylor and Sutcliffe, 1963; Paffenhöfer and Strickland, 1970; Poulet, 1976).

Particle data collected by Paffenhöfer (Figures 20-23) for Onslow Bay waters show approximately $120 \mu \mathrm{g} C / 1$. Chlorophy11 a data collected at the same time show values of $0.7 \mu \mathrm{g}$ chlorophyll a/1, a very low value. ${ }^{8}$ This concentration converts to approximately $40 \mu \mathrm{g} \mathrm{C} / 1$ for a well growing phytoplankton population and when subtracted from the particle value, a value of $80 \mu \mathrm{g} \mathrm{C} / 1$ is obtained. ${ }^{9}$ This value is high and leads one to believe that detritus could be an important source of nutrients in system aș weil as an important food source for zooplankton.

\footnotetext{
${ }^{8}$ W. M. Dunstan, personal comnunication, July 1976.

$9_{\text {G. }}$ A. Paffenhöfer, personal communication, July 1976.
} 


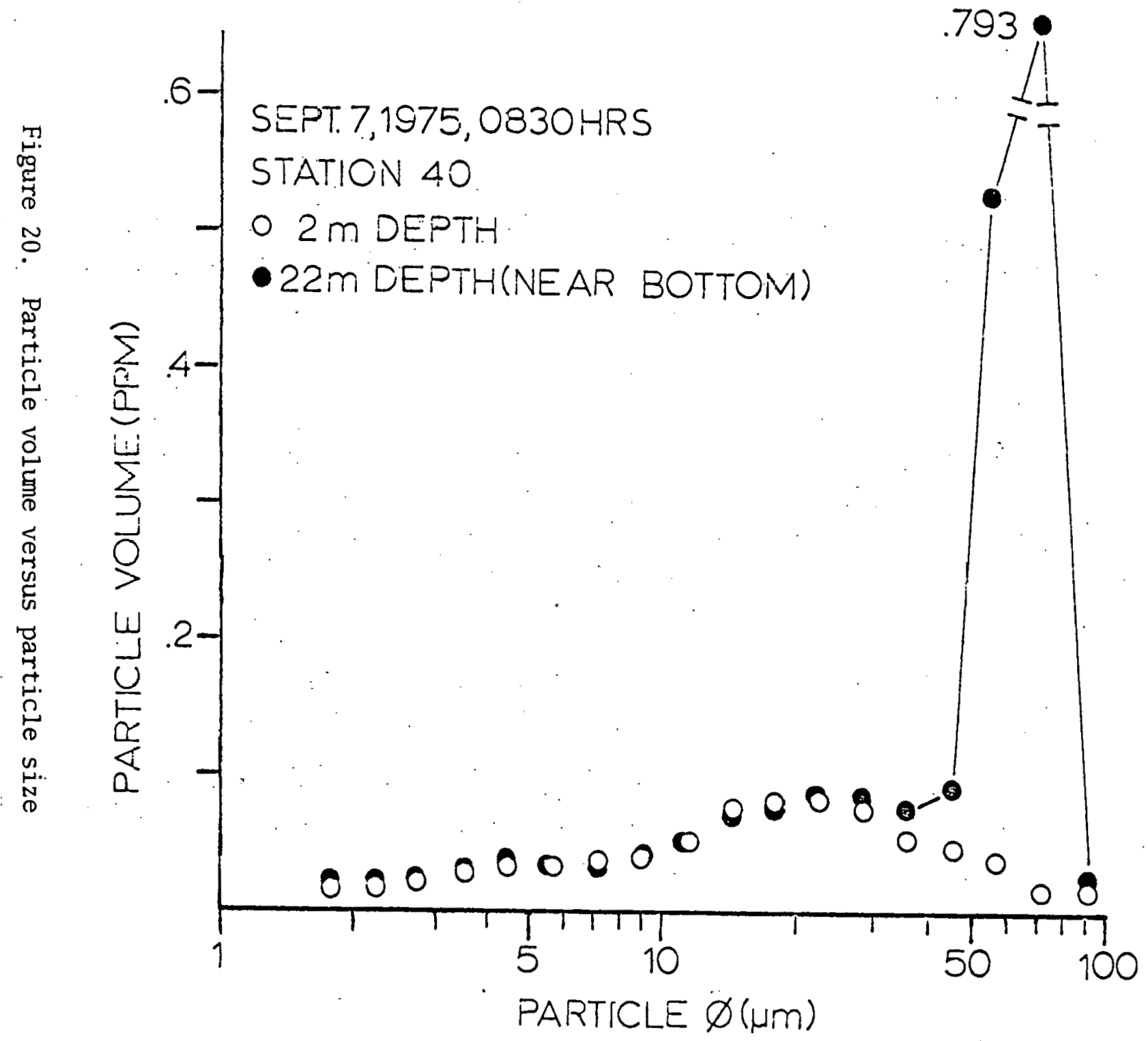




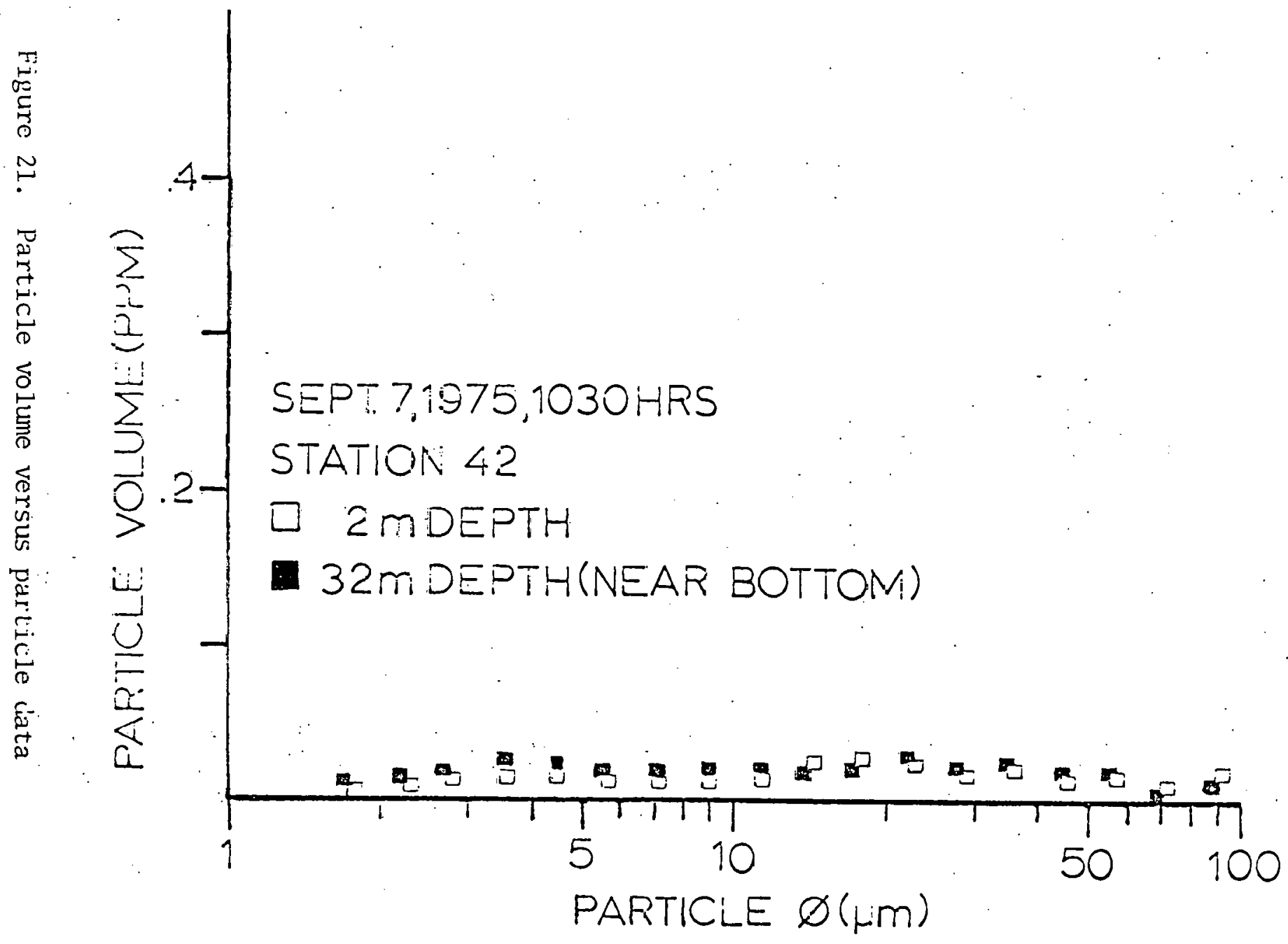




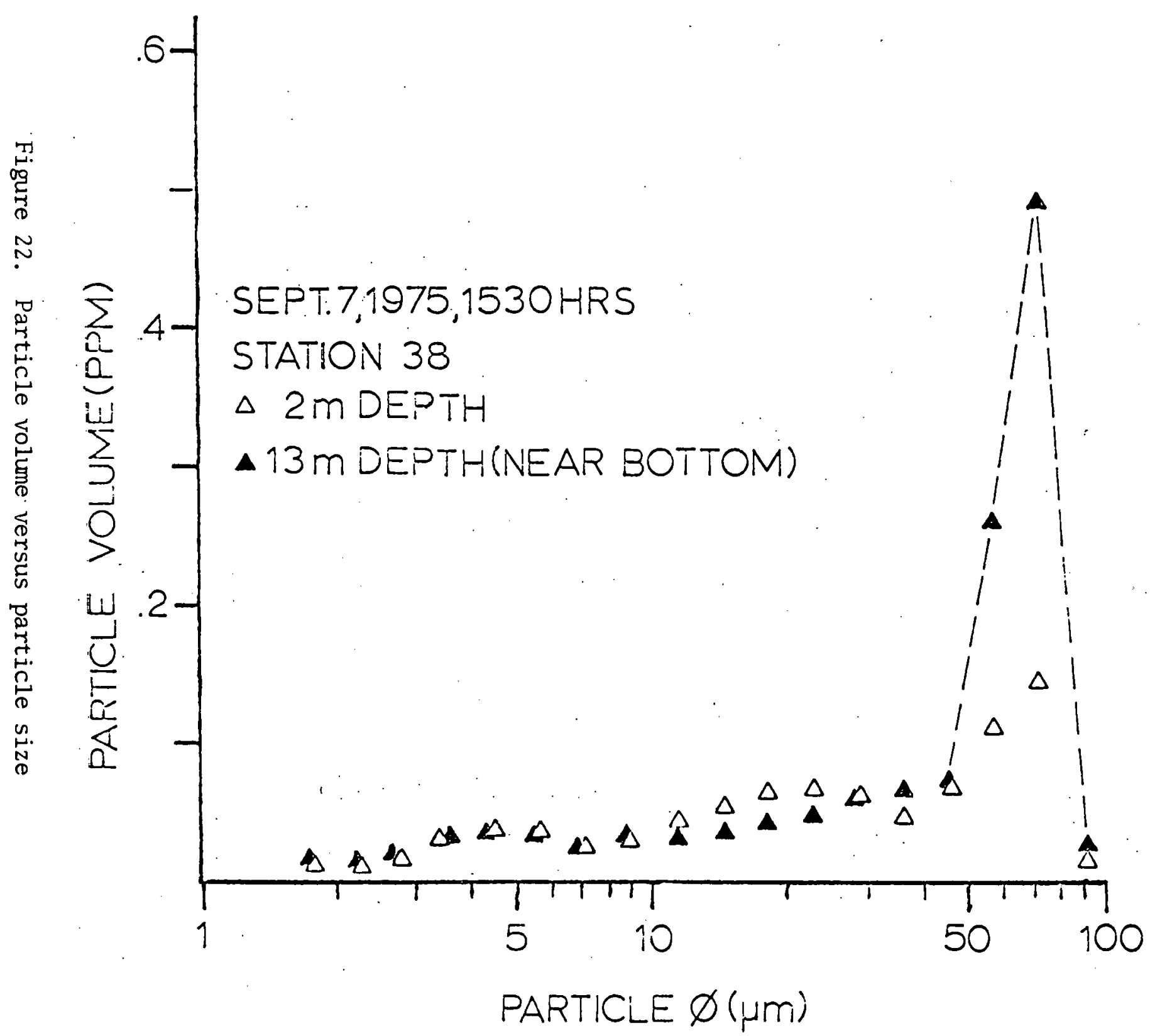




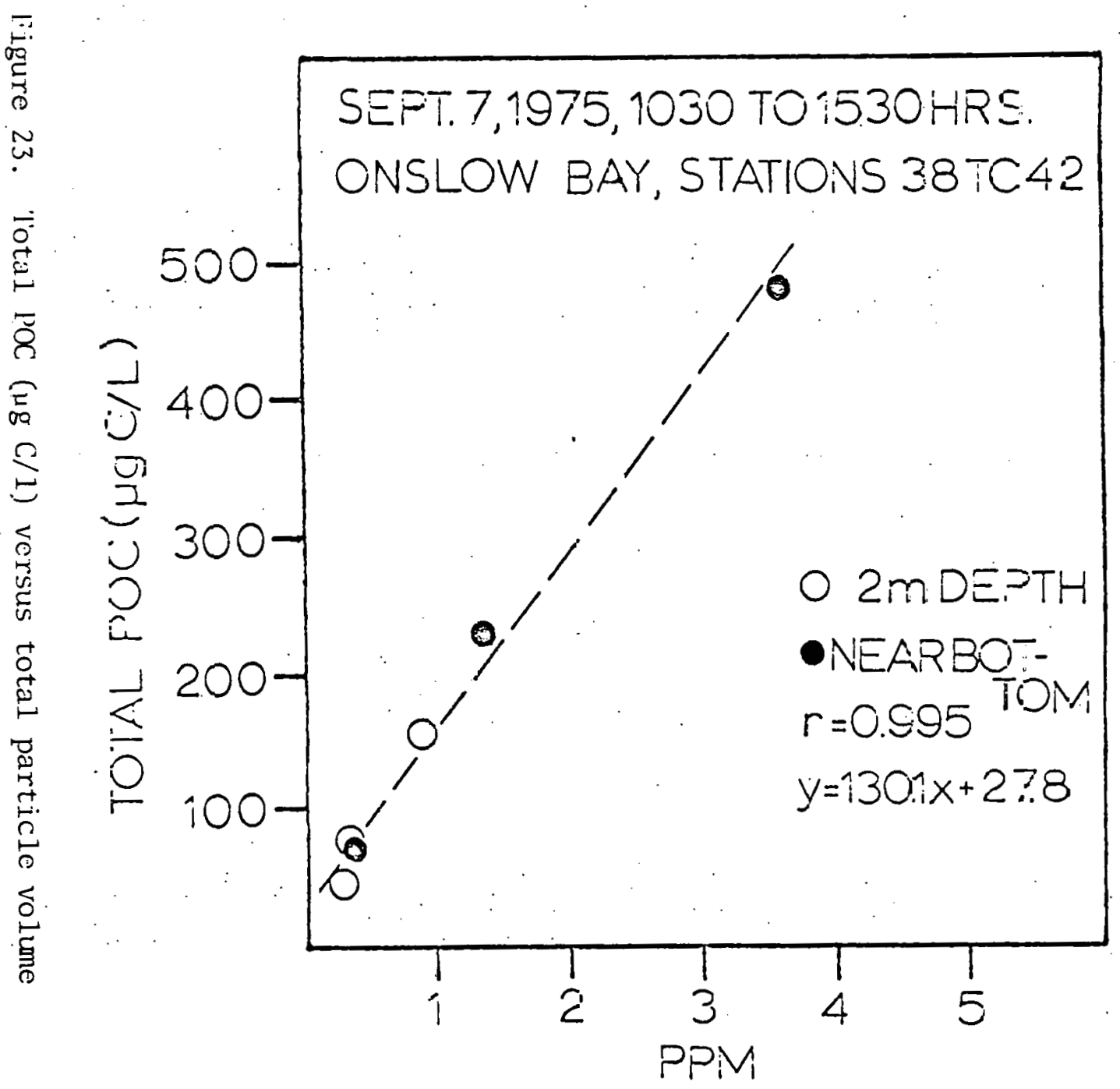

TOTAL PARTICLE VOLUME(i.6to:00 $\mu M$ $\varnothing)$ 
If one assumes that 2-15 percent of the detrital decomposition is nitrate, then values ranging from 1.6 to $12 \mu \mathrm{g}$-at $\mathrm{NO}_{3} / 1$ are obtained. If one further assumes a regeneration rate of approximately two days (O'Brien and Wrobleski, 1973), a range of values from $7.86 \times 10^{-6} \mathrm{\mu g}$-at $\mathrm{NO}_{3} / 1-\sec$ to $6.94 \times 10^{-5} \mu \mathrm{g}$-at $\mathrm{NO}_{3} / 1-\mathrm{sec}$ is obtained for detrital decomposition.

\section{Nitrogen Fixation by Blue Green Algae}

Dugdale et al. (1961) reported that Oscillatoria sp. (Trichodesmium), a planktonic marine myxophyte, is able to fix atmospheric nitrogen. Subsequent work has supported this finding (Dugdale et al., 1964; Goering et al., 1966; Bunt et al., 1970; Carpenter, 1973; Mague et al., 1974). Oscillatoria spp. occur throughout the tropical and subtropical oceans and are of interest because nitrogen fixation is one method by which nitrogen can be introduced into the euphotic zone.

Dunstan found Oscillatoria spp. to be present in coastal waters in concentrations of approximately 1000 filaments/1iter. Using this concentration and the nitrogen fixation rates determined by Carpenter and McCarthy (1975) for Oscillatoria thiebautii in the western Sargasso Sea, he calculated a nitrogen fixation rate of $1.14 \mu g$-at/1-year for Georgia Bight waters. ${ }^{10}$ When converted to $\mu g-a t / 1-\mathrm{sec}$, the value for nitrogen fixation becomes $3.65 \times 10^{-6} \mu \mathrm{g}$-at/1-sec.

\section{Regeneration of Nitrate from Bottom Sediments}

The effect of nitrogen regeneration from the ocean bottom usually has not been considered in describing sources or sinks of nitrogen in

${ }^{10}$ W. M. Dunstar, Pruductivity in the South Atlantic Bight, Seminar, North Carolina State University, Raleigh, March 1976. 
nearshore ocean waters. Although it has been presumed that the bottom is an important site of nitrogen remineralization, attempts to estimate benthic regeneration have been confined to lakes (Mortimer, 1941, 1942), indirect inferences from concentration of pore water (Rittenberg et al., 1955) or laboratory incubations which indicate that the bottom is only a minor source of nutrients (Harris, 1959) or even a nitrogen sink in anoxic waters. In some areas, benthic regeneration is thought to account for a large percentage of nutrient regeneration.11 However, little field work has been done to measure the nutrient flux from bottom sediments. Rowe et al. (1975) performed in situ experiments, in which a given amount of bottom sediment was incubated for various lengths of time and the amount of nutrient regeneration measured. These measured values were compared to predicted values. The results of these experiments are shown in Table 2 .

For the purposes of this model, the nitrate flux for the month of July was chosen since this was the highest rate measured and this time period corresponds to that of an intrusion.

This term is added to the right-hand side of the bottom boundary condition (Equation 2a), which allows flux of nitrate into or out of the bottom. For the characteristic numbers chosen (Appendix B) the value calculated for regeneration of nitrate is of order $10^{-3}$. Because of: loss of significance in the computer, the values obtained for the bottom boundary condition (assuming no flux) were equal to or one order of magnitude less than the regeneration term. Therefore, for the

${ }^{11}$ Scott Nixon, Benthic Organisms and Their Role in Nutrient Regeneration, Seminar, North Carolina State University, Raleigh, April 1976. 
Table 2. Sediment-water nutrient flux ${ }^{\mathrm{a}}$

\begin{tabular}{r|c|c|c|c|c|c}
\hline & \multicolumn{5}{|c}{ Nutrient flux $\left(\mu \mathrm{g}\right.$-atom $\left.\mathrm{m}^{-2} \mathrm{~h}^{-1}\right)$} \\
\hline and depth & Date & $\mathrm{NH}_{4}$ & $\mathrm{NO}_{2}$ & $\mathrm{NO}_{3}$ & $\mathrm{~N}$ & $\mathrm{PO}_{4}$ \\
\hline
\end{tabular}

Buzzards

$\begin{array}{lllll}\text { Bay }(17 \mathrm{~m}) \text { November } 1973 \quad 68.8 & 0.05 & 0.15 & 69.00\end{array}$

Buzzards

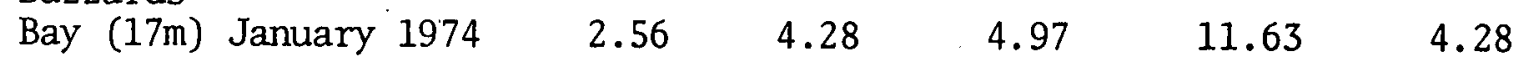

Buzzards

$\begin{array}{llllll}\text { Bay (17il) February } 1973 & 18.70 & 1.19 & 21.08 & 5.17 & 10.35\end{array}$

Buzzards

Bay $(17 \mathrm{~m})$ June $1974: \quad 124.0 \quad-1.96 \quad 2.93 \quad 124.87 \quad-14.87$

Lel Pond

$\begin{array}{lrrrrrr}\text { (2m) July } 1974 & 7.87 & 0.44 & 1.75 & 10.06 & 6.6 \\ & & 117.99 & 0.94 & 1.50 & 117.43 & 21.57 \\ & 127.91 & 0.46 & 0.0 & 128.37 & 19.46\end{array}$

\begin{tabular}{c|c|c|c|c|c}
\hline $\begin{array}{c}\text { Bottom } \\
\mathrm{O}_{2} \text { demand } \\
\left(\mathrm{m} 1 \mathrm{~m}^{-2} \mathrm{~h}^{-1}\right)\end{array}$ & $\begin{array}{c}\text { Predicted } \\
\text { N produc- } \\
\text { tion }\end{array}$ & $\begin{array}{c}\text { Observed } \\
\text { N as per- } \\
\text { cent of } \\
\text { predicted N }\end{array}$ & $\begin{array}{c}\text { Mean } \mathrm{O}_{2} \\
\text { concen- } \\
\text { tration } \\
\left(\mathrm{m1} \mathrm{I}^{-1}\right)\end{array}$ & $\begin{array}{c}\text { Duration } \\
\mathrm{h})\end{array}$ & $\begin{array}{c}\mathrm{T} \\
(\mathrm{C})\end{array}$ \\
\hline 22.08 & 64.9 & 106 & 4.8 & 2.15 & 7.7 \\
10.90 & 32.1 & 36 & 7.8 & 6.00 & 1.5 \\
10.35 & 30.4 & 69 & 8.3 & 2.6 & 1.6 \\
41.89 & 123.3 & 101 & 4.7 & 5.25 & 16.0 \\
14.96 & 44.0 & 23 & 6.2 & 4.5 & 20 \\
51.59 & 151.8 & 77 & 4.7 & 10.5 & 20 \\
26.88 & 79.1 & 162 & 2.7 & 13.0 & 20 \\
\hline
\end{tabular}

avalues from G. T. Rowe, C. H. Clifford, K. L. Smith and P. L. Hamilton, Nature, Vol, 255, May 15, 1975, pp. 215-217. 


\section{4}

characteristic parameters in this model, regeneration terms of this size are too small to be significant. For a deeper system, or a smaller value of the vertical diffusion coefficient, values of this magnitude may be significant.

\section{Scaling of Biological Dynamics}

In order to obtain useful results, Equation (6) has been simplified and formulated in a manner which isolates the processes of interest, that is, it has been multiplied by a factor so that the coefficients are nondimensional. This allows one to single out the dominant processes and determine the relative importance of each.

In Equation (5) the biological terms are multiplied by the nondimensional number $\frac{\mathrm{S}_{\mathrm{L}} \mathrm{B}_{\mathrm{L}}}{\mathrm{H}_{\mathrm{L}} \mathrm{N}_{\mathrm{L}}}$, where $\mathrm{S}_{\mathrm{L}}$ and $\mathrm{H}_{\mathrm{L}}$ are the characteristic shelf length and depth respectively, $\mathrm{N}_{\mathrm{L}}$ is the characteristic nitrate concentration and $\mathrm{B}_{\mathrm{L}}$ is the characteristic biological activity. A closer look at this term shows that $\frac{H_{L}}{S_{L}}$ is an aspect ratio. For a given ratio of $\frac{\mathrm{H}_{\bar{L}}}{\mathrm{~S}_{\mathrm{L}}}$, the size of the aspect ratio will change the effect of the biology on the system. For a shallow system (such as Onslow Bay) the biological activity is more important than for a deep system, which is what one would expect.

The total biological activity is assumed to be

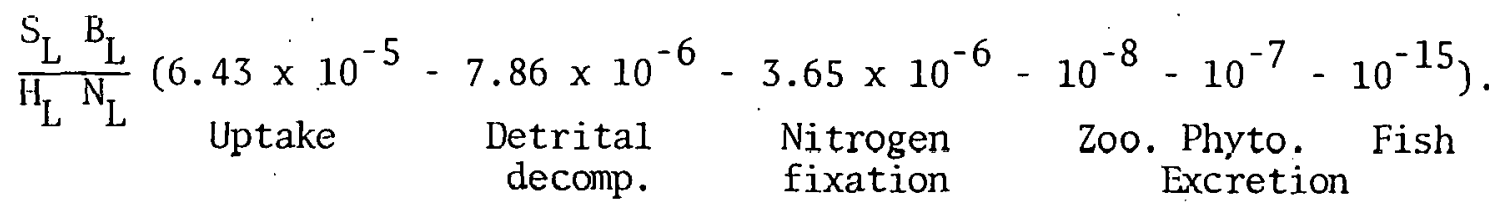


Scaling everything relative to nutrient uptake results in the following:

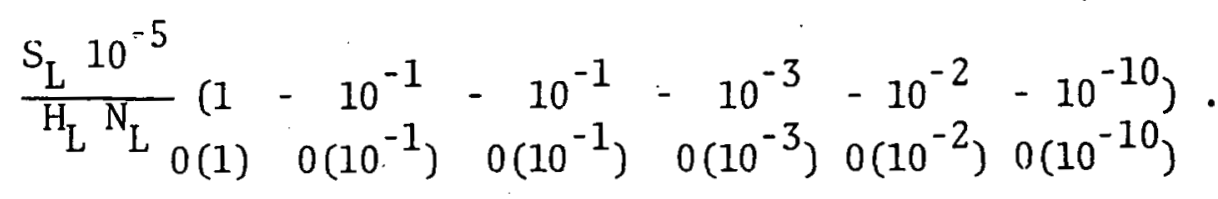

From the nondimensionalized equation it is readily apparent that extracelluar release of nitrate by phytoplankton and excretion by zooplankton and fish are small compared to nutrient uptake and can probably be neglected. Decomposition of detritus and nitrogen fixation by Blue Greens are of the same order and probably serve as nitrate sources for the system in the absence of an intrusion.

The upper limit for detrital decomposition is of the same order as nitrate uptake. This indicates that decomposition of detritus could balance uptake of nitrate by phytoplankton in the absence of high ambient concentrations of the nutrient. This appears to be an important process in system dynamics and should not be neglected. 
A problem faced by physical oceanographers, engineers and applied mathematicians working in a given field of study is to find solutions to the basic equations arising in that field while employing a minimum number of simplifying assumptions. Unfortunately, the equations governing oceanographic physical processes are usually nonlinear partial differential equations for which classical methods for analytic solutions do not work. Therefore, other types of approaches, such as perturbation expansion and asymptotic approximation techniques have been developed to resolve the inability of analytical approaches to work. A method, well known in the aeronautical field, which allows one to take a nonlinear partial differential equation in two independent variables and reduce it to a nonlinear ordinary differential equation in one independent variable is used in the model presented in this paper. The resulting equations have been solved using numerical methods.

For the mathematical model presented in this paper, the method of separation transformation theory was used to reduce the number of independent variables in the system. The term separation transformation is used rather than similarity transtormation since similarity transtormations are concerned with a complete boundary layer problem rather than reduction of the number of independent variables (Hansen, 1964).

In this method, the concentration of any physical, chemical or biological element may be redefined in terms of the nondimensional position paraneters $n$ and $X / L(\xi)$. One then assumes that the function has a particular dependence on $\xi$ which allows that parameter to be 
eliminated from the equation. This is the source of the similarity conditions (the relationships among the "alphas").

In this model; the following variable transformations are made.

$$
\begin{array}{ll}
\xi=\frac{x}{L}, n=\frac{z}{h_{L}}(\xi)^{\alpha} & \text { Coordinate } \\
h(x)=h_{L}\left(\frac{x}{L}\right)^{-\alpha} & \text { Bottom profile } \\
N=N_{O, L}+\Delta N_{L}\left[\theta(n)\left(\frac{x}{L}\right)^{\alpha}-\theta(0)\right] F_{1}(t) & \text { Nitrate } \\
\psi=\psi_{L} F_{2}(t) \phi(n)\left(\frac{x}{L}\right)^{\alpha} & \text { Streamfunction } \\
B=B_{L} F_{3}(t) G(n)\left(\frac{x}{L}\right)^{\alpha} & \text { Biological processes } \\
D_{x}=D_{L} F_{4}(t)\left(\frac{x}{L}\right)^{\alpha}{ }^{\alpha} & \text { Horizontal eddy diffusion } \\
D_{z}=D_{V} F_{5}(t)\left(\frac{x}{L}\right)^{\alpha}{ }^{\alpha} & \text { Vertical eddy diffusion }
\end{array}
$$

The meaning of the terms in the nitrate transformation will be discussed and the description for the corresponding terms applies to all other transformations.

$N_{L}$ is a scaling parameter which represents some characteristic nitrate concentration. $F_{1}(t)$ allows the expression for nitrate concentration to be a function of time. $\theta(n)\left(\frac{\alpha}{L}\right)^{\alpha} 1-\theta(0)$ is the transformed nitrate concentration, where $\theta(n)$ is the transformed nitrate value and $\theta(0)$ is the transfomed surface nitrate value. The $\left(\frac{x}{L}\right)$ term allows the curve that describes nitrate concentration to stretch or shrink in the vertical as it moves about in the system. The similarity parameter, $\alpha_{1}$, determines the horizontal gradient of nutrient distribution. 
It is assumed that $D_{x}$ and $D_{z}$ change only in the horizontal, $(x)$, direction. Therefore, the transform for these two variables does not include a function of $n$.

After making the transformations and substituting the same into Equation (1), the following transformed equation ${ }^{1}$ is obtained

$$
\begin{aligned}
& \theta^{\prime \prime}\left[\eta^{2} \alpha^{2}+\frac{D_{V} F_{5}{ }^{2}}{D_{\bar{L}} F_{4} h_{\bar{L}}^{2}}\right]+\theta^{\prime}\left[n \alpha\left(\alpha+2 \alpha_{1}-1\right)+\alpha_{4} n \alpha-\frac{\psi_{L} F_{2} L}{D_{L} F_{4} h_{L}} \alpha_{2} \phi\right] \\
& +\theta\left[\alpha_{1}\left(\alpha_{1}-1\right)+\alpha_{4} \alpha_{1}-\frac{L^{2} \Gamma_{1}^{*}}{D_{L} h_{L} F_{4}}+\frac{L \psi_{L} F_{2}}{h_{L} D_{L} F_{4}} \alpha_{1} \phi^{\prime}\right]=\text { Bio1. terms }
\end{aligned}
$$

with the following similarity conditions:

$$
\alpha_{1}=2\left(\alpha_{2}+\alpha_{1}+\alpha-1\right)=2\left(\alpha_{4}+\alpha_{1}-2\right)=\alpha_{5}+\alpha_{1}+2 \alpha_{\alpha}=\alpha_{3} .
$$

One then assumes steady state which will eliminate the time dependent terms from the equation and will result in the following relation:

$$
\begin{aligned}
& \left.\theta^{\prime \prime}\left[n^{2} \alpha^{2}+\frac{\mathrm{D}_{V}^{L^{2}}}{\mathrm{D}_{\mathrm{L}} \mathrm{h}_{\mathrm{L}}^{2}}\right]+\theta^{\prime} n \alpha\left(\alpha+2 \alpha_{1}-1\right)+\alpha_{4} n \alpha-\frac{\psi_{L}{ }^{L}}{\mathrm{D}_{L} h_{L}} \alpha_{2} \phi\right] \\
& +\theta\left[\alpha_{1}\left(\alpha_{1}-1\right)+\alpha_{4} \alpha_{1}-\frac{L \psi_{L}}{h_{T_{1}} D_{T_{1}}} \alpha_{1} \phi^{\prime}\right]=\text { Biol. terms. }
\end{aligned}
$$

Assuming steady state also eliminates the first similarity condition, which is derived from the time derivative of $N$, i.e.., $\frac{\partial \mathrm{N}}{\partial t}$.

The following constraints are imposed on the system:

1. No flux of nutrients in or out of the surface;

2. No flux of nutrients in or out of the bottom;

1. Where ( )" is $\frac{\partial}{\partial \eta} ;()$ " is $\frac{\partial^{2}}{\partial \eta^{2}} ;() *$ is $\frac{\partial}{\partial t}$ 
3. Difference condition imposed at the shelf break. Bottom nitrate concentration minus the surface nitrate concentration is equal to some $\Delta \mathrm{N}$. (a constant for the time independent case).

Expressed mathematically, these constraints become:

1a. $\nabla \cdot \mathrm{N} \overrightarrow{\mathrm{n}}=0$;

2a. $\mathrm{q}_{\mathrm{V}} \frac{\partial \mathrm{N}}{\partial \mathrm{z}}+\mathrm{D}_{\mathrm{H}} \frac{\partial \mathrm{N}}{\partial \mathrm{x}} \cdot \frac{\mathrm{dH}}{\mathrm{dx}}=\mathrm{N}_{\text {bottom }}$;

3a. $N\left(L, H_{L}\right)-N(L, 0)=\Delta N$.

Substituting the assumed transforms into constraints $1 \mathrm{a}, 2 \mathrm{a}$ and $3 \mathrm{a}$ yields:

$$
\begin{aligned}
& \frac{\partial \theta}{\partial \eta}(0)=0 \\
& \frac{\partial \theta}{\partial \eta}(1)+\frac{h_{L}^{2} D_{L}}{L^{2} D_{V}}\left[\frac{\partial \theta}{\partial \eta}(1) \alpha^{2} n+\theta(1) \alpha_{1} \alpha\right]=0 \\
& \theta(1)-\theta(0)=\frac{\Delta N}{N_{L} F_{1}(t)}
\end{aligned}
$$

The complete mathematical system is second order and has an eigenvalue $\alpha_{1}$, in it. Equations (1.1) and (1.2) are the boundary conditions for the differential equation and Equation (1.3) is the condition which determines the characteristic parameter $\alpha_{1}$. 
In this mode1, the vertical and horizontal velocities have been defined in terms of a stream function, $\psi$, where $u=\frac{\partial \psi}{\partial z}$ and $w=\frac{\partial \psi}{\partial x}$. The introduction of the stream function allows the continuity equation

$$
\frac{\partial u}{\partial x}+\frac{\partial w}{\partial z}-0
$$

to be identically satisfied.

The circulation pattern chosen for this model resembles that described by Blanton (1971, Figure 4) and derived by Pietrafesa (1973) and depicts a one-celled circulation with water moving onshore at the bottom and offshore at the top.

To model the circulation, a bounded, barotropic Edman (1905) system with a finite depth was chosen. The balance being considered is the Coriolis force balancing the pressure gradient, turbulent friction, surface wind stress and bottom stress.

The equation describing the circulation is derived from the following momentum balances:

$$
\begin{aligned}
& \dot{x} \text { momentım equation }-f v=-\frac{1}{\rho} \frac{\partial P}{\partial x}+A \frac{\partial^{2} u}{\partial z^{2}} \\
& y \text { momentum equation } f u=-\frac{1}{F^{\prime}} \frac{\partial P}{\partial y}+A \frac{\partial^{2} v}{\partial z^{2}} . \\
& z \text { momentum equation } \frac{\partial P}{\partial z}=g \rho
\end{aligned}
$$

For purposes of this study, the baroclinic effects have been neglected although they may be important and can be included in the model. 
Differentiating, substituting and performing the separation transformation, $\phi(n)=\frac{\psi(x, z)}{\psi_{L}}\left(\frac{x}{L}\right)^{-\alpha}$, for the stream function yields

$$
\frac{d^{5} \phi}{d_{n}^{5}}+4 T^{4} \frac{\partial \phi}{\partial \eta}=0
$$

as the combined equation for Equation (8), (9) and (10). The solution of Equation (11) is:

$$
\phi(n)=e^{T n}\left(A_{1} \operatorname{Cos} T_{n}+A_{2} \operatorname{Sin} T_{n}\right)+e^{-T \eta}\left(A_{3} \operatorname{Cos} T_{n}+A_{4} \operatorname{Sin} T \eta\right)+A_{5}
$$

The following constraints are placed in the system:

1. No flow in or out of the surface;

2. No flow in or out of the bottom;

3. No slip along the bottom;

4. Surface shear balances $x$ wind stress;

5. Surface shear balances y wind stress.

Expressed mathematically these become:

1a. $\phi(0)=0$

2a. $\phi(1)=0$

3a. $\frac{\partial \phi}{\partial n}(1)=0$

4a. $\frac{\partial^{2} \phi}{\partial \eta^{2}}(0)=C_{1} T_{x S}$

5a. $\frac{\partial^{4} \phi}{\partial \eta^{4}}(0)=C_{1} r_{y S}$

where $C_{1}=\frac{\mathrm{H}_{\mathrm{L}}^{2}}{\mathrm{D}_{\mathrm{T}} \psi_{\mathrm{T}_{1}}}, \mathrm{C}_{2}=\frac{\mathrm{H}_{\mathrm{L}}^{4} \mathrm{f}}{\mathrm{R}_{\mathrm{V}}^{2} \psi_{\mathrm{L}}}$. 
These boundary conditions give the following expressions for the constants:

$$
\begin{aligned}
A_{1}= & \left(e^{T} D\left(\operatorname{Sin}(T) \operatorname{Cos}(T) \operatorname{Cosh}(T)+\operatorname{Sin}^{2}(T) \operatorname{Sinh}(T)\right)\right. \\
& -\operatorname{Sin}(T) \operatorname{Cosh}(T)(\operatorname{Cos}(T)+\operatorname{Sin}(T)) \cdot\left(D e^{T}+A_{5} e^{-T}\right) \\
& \left.A_{5}\left(C^{-T} \operatorname{Cos}(T)-1\right) \cdot(\operatorname{Cos}(T) \operatorname{Cosh}(T)+\operatorname{Sin}(T) \operatorname{Sinh}(T))\right) / \\
& 2(\operatorname{Cos}(T) \operatorname{Sin}(T)-\operatorname{Sinh}(T) \operatorname{Cosh}(T))) \\
A_{2}= & D \cdot A_{4} \\
A_{3}= & -A_{5}-A_{1} \\
A_{4}= & \left(-A_{1} \operatorname{Cos}(T) 2 \operatorname{Sinh}(T)-e^{T} D \operatorname{Sin}(T)+e^{-T} \cdot A_{5} \operatorname{Cos}(T)-A_{5}\right) / \\
& (2 \operatorname{Sin}(T) \operatorname{Cosh}(T)) \\
A_{5}= & \frac{C_{2} T_{y S}}{4 T^{4}} \quad
\end{aligned}
$$

where $\mathrm{T}=\mathrm{H}_{\mathrm{L}} \sqrt{\mathrm{f} \mathrm{D_{V } ^ { 2 }}}$. and $\mathrm{D}=\frac{\mathrm{C}_{1} \mathrm{~T}_{\mathrm{xS}}}{2 \mathrm{~T}^{2}}$.

By considering varying wind direction, one obtains different circulation patterns. However, for this problem, the primary interest is in the wind blowing from the southwest, since this sets up an Ekman transport olfshore. Figures 24 through 27 show flow profiles $(u$ and $w$ velocities) that are generated by varying wind directions.

For a more detailed discussion of the circulation model, one is referred to Pietrafesa (1973). 


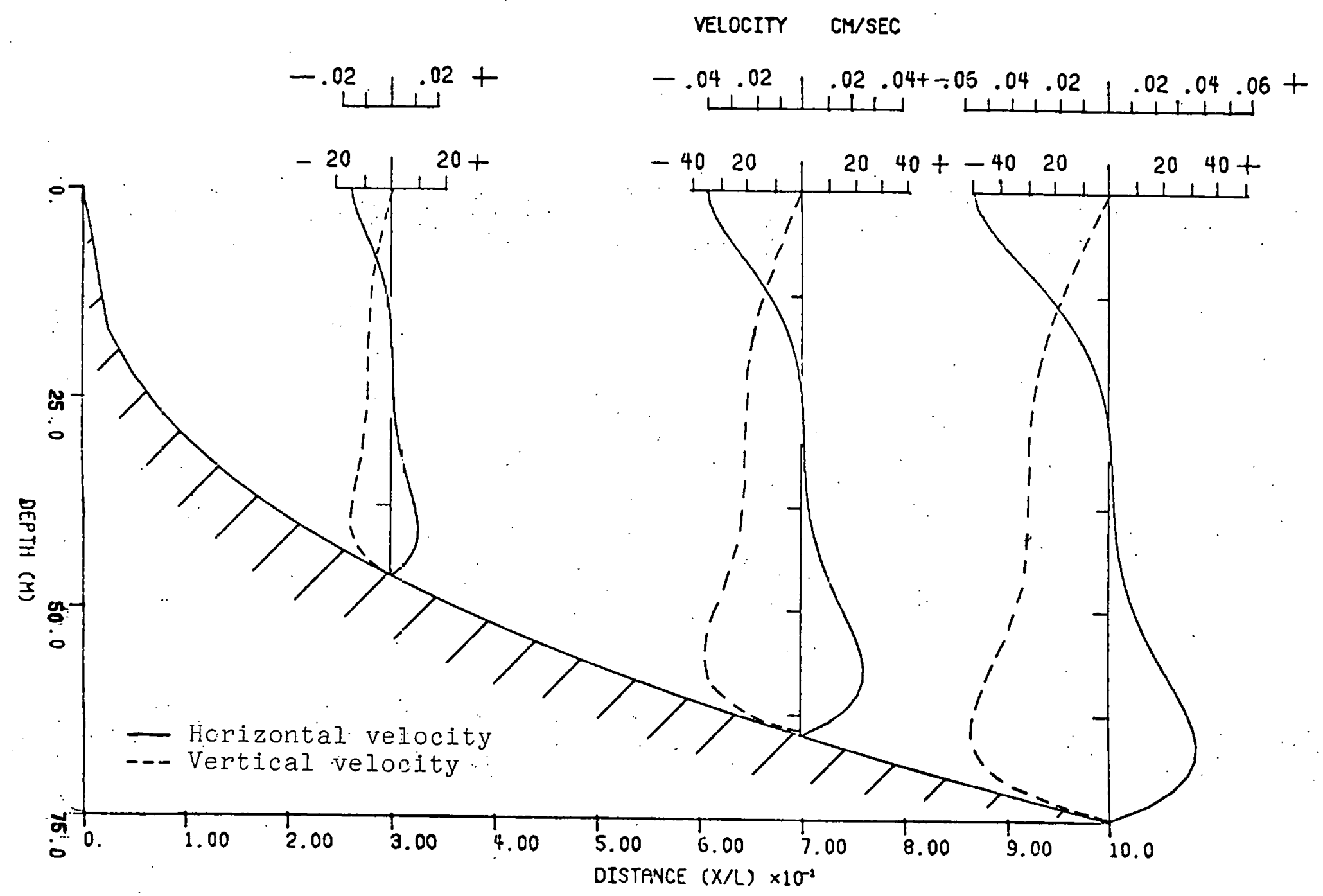

Figure 24. Horizontal and vertical velocity profiles for a northeasterly wind of 1 dyne/ $\mathrm{cm}^{2}$ 


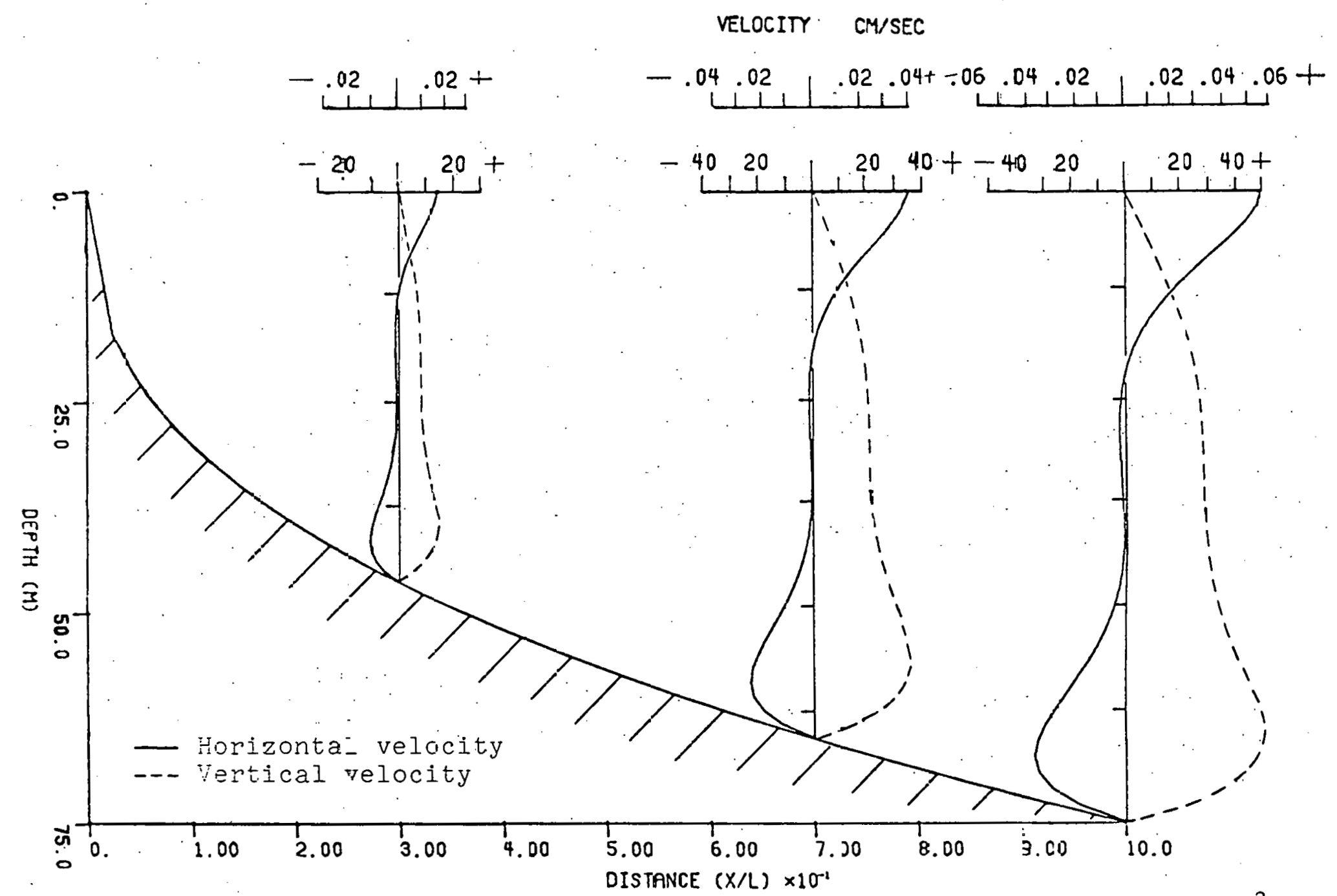

Figure 25. Horizontal and vertical velocity profiles for a southwesterly wird of 1 dyne $/ \mathrm{cm}^{2}$ 


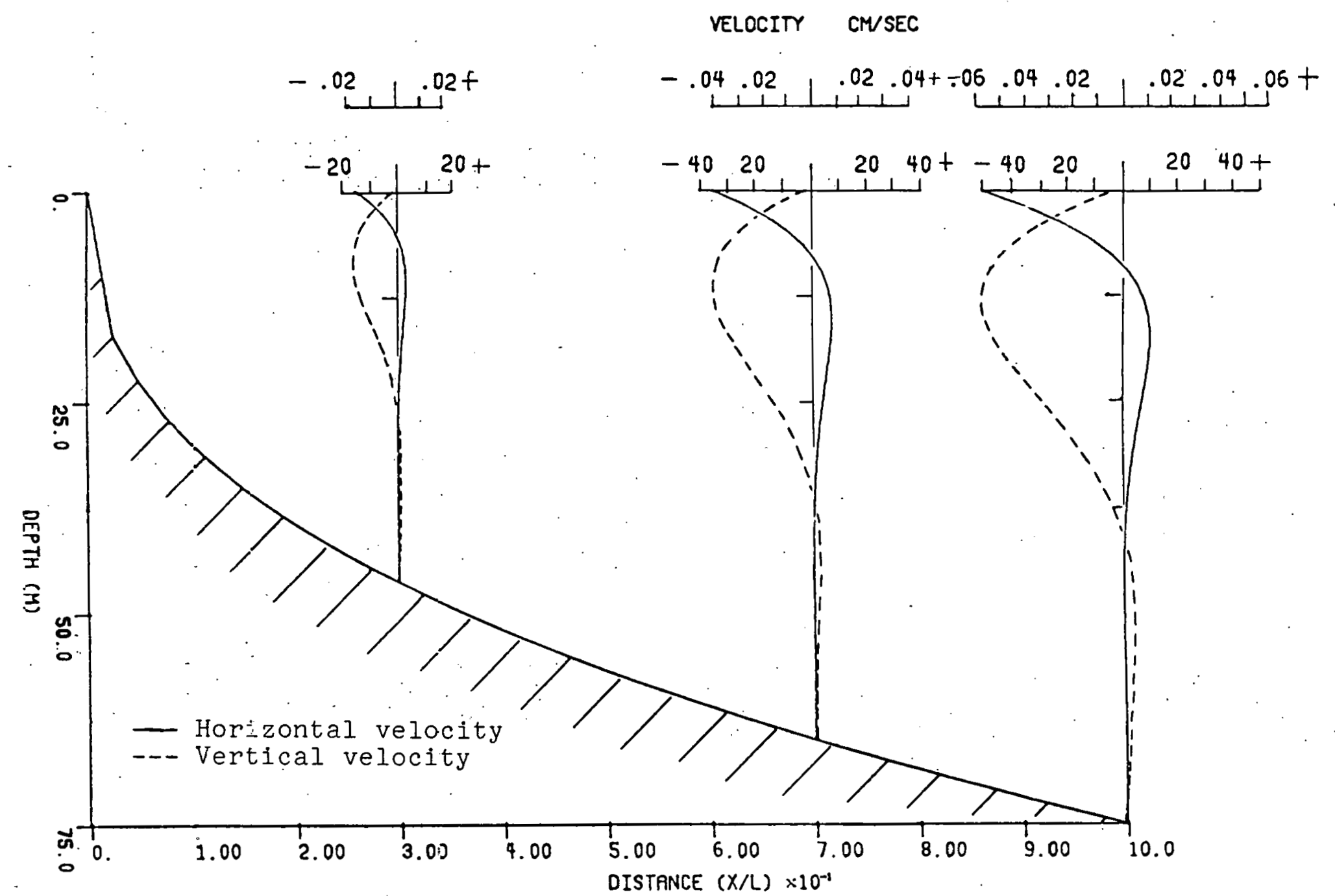

Figure 26. Horizontal and vertical velocity profiles for a southeasterly wind of $1 \mathrm{dyne} / \mathrm{cm}^{2}$ 


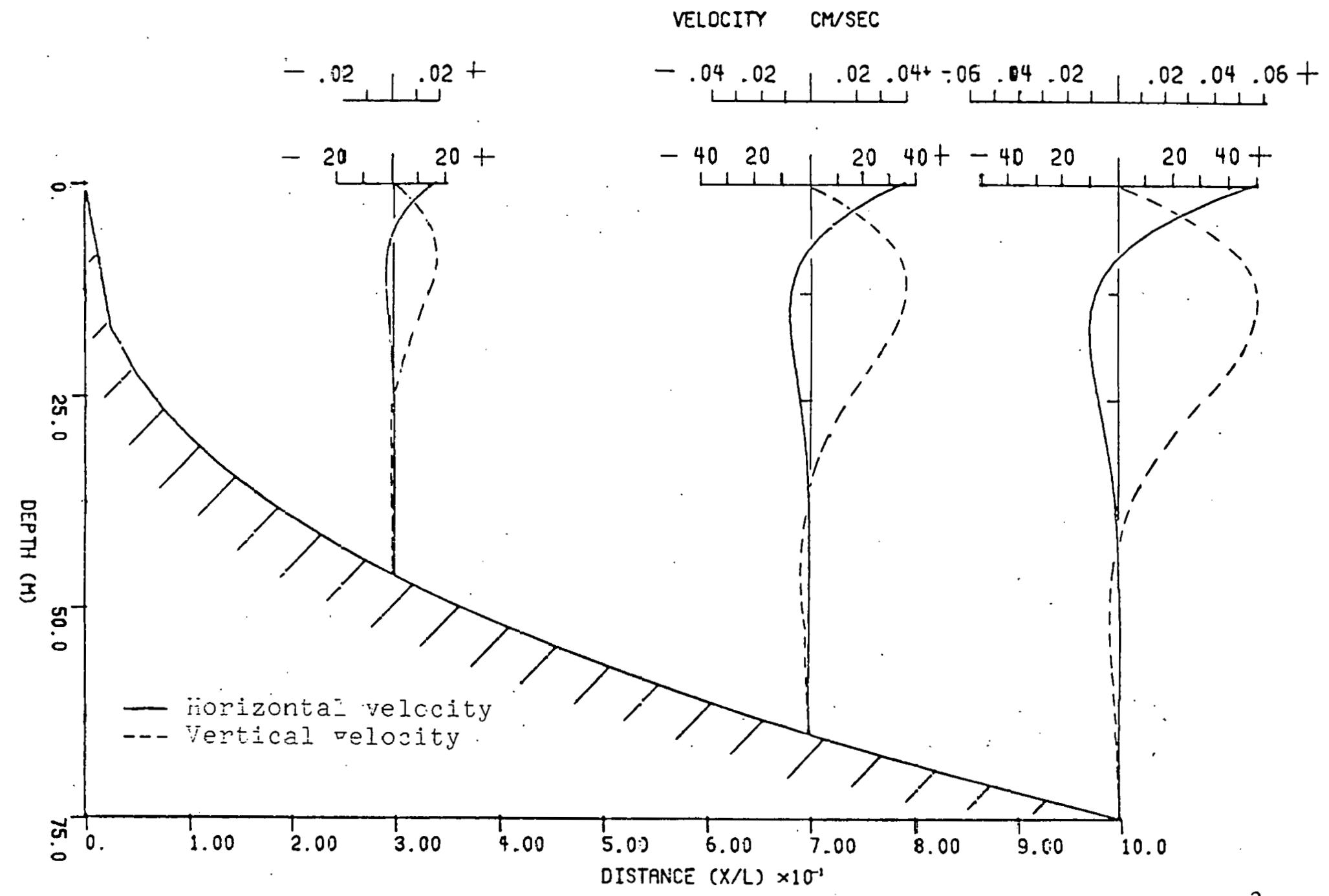

Figure 27. Horizontal and vertical velccity profiles for a northwesterly wind of $1 \mathrm{dyne} / \mathrm{cm}^{2}$ 
CHAPTER VIII

BOTTOM PROFILE

The similarity parameter describing the bottom profile was assigned different values. The significance of variable bottom topography on the system is discussed in the section dealing with results. Bottom profiles for $\alpha=-1.2$ and -.4 are shown in Figure 28. 


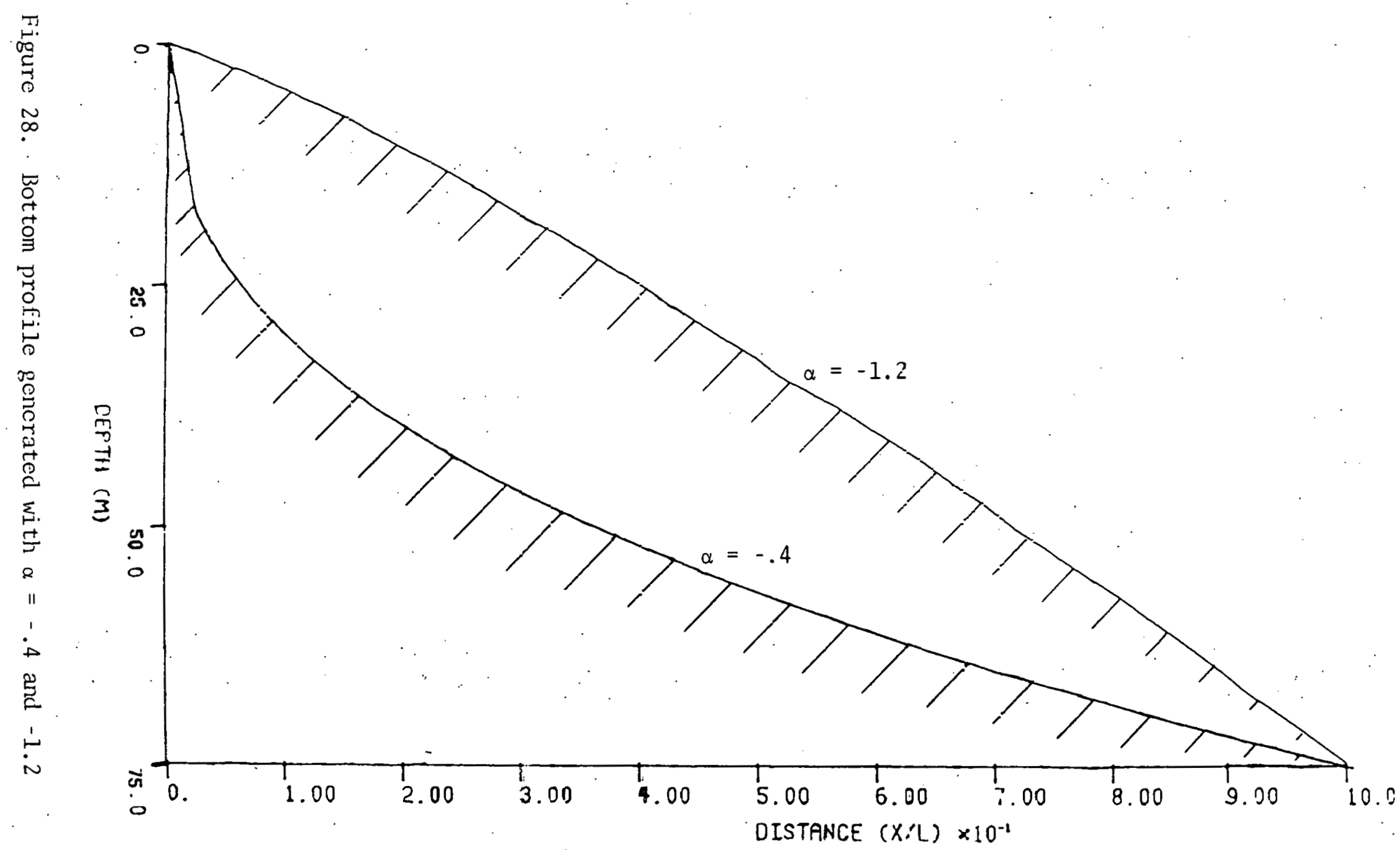


CHAPTER IX

DISCUSSION OF RESULTS

The results presented in the following sections are for three general cases:

1. Advectively dominant system;

2. Diffusively dominant system;

3: Advectively-Diffusively balanced system.

The bottom similarity parameter, wind direction and biological terms have been allowed to vary. It is recognized that many combinations of parameters are possible; however, the cases presented here represent what is considered to be a meaningfully adequate minimum number of situations.

\section{Advection and Diffusion Terms}

The characteristic magnitude in Equation (6) representing the relative importance of advection to horizontal diffusion is $\frac{\psi_{\mathrm{L}} \mathrm{L}}{\mathrm{D}_{\mathrm{L}} \mathrm{H}_{\mathrm{L}}}$ and that representing the relative importance of vertical to horizontal diffusive mixing time scales is $\frac{\mathrm{D}_{\mathrm{V}} \mathrm{L}^{2}}{\mathrm{D}_{\mathrm{L}} \mathrm{H}_{\mathrm{L}}^{2}}$. The value of the second term also allows one to determine whether vertical or horizontal diffusion is more important in the system. The importance of this term may be increased or decreased by the length and width scales chosen. For a shallow, wide system, vertical diffusion could be more important than horizontal diffusion.

\section{Advectively Dominant System}

Several cases were tried for varying ratios of advection to horizontal diffusion (2-5) combined with a value of .1 for the ratio of vertical to horizontal mixing time scales. For all of these cases, it 
was not possible to find a realistic value for the horizontal stratification parameter, $\alpha_{1}$, such that the bottom boundary condition was satisfied. This indicates that some other process, i.e.,.horizontal or vertical diffusion, is playing a role in the distribution and supply of the nutrient.

\section{Diffusively Dominant System}

lior this cáse, lle raliu uf diffusive mixtng tIme scales wảs chosen to equal 1.0 and the ratio of advection to horizontal diffusion was chosen to be 0.5 . The value for the advective term indicates that advection is small or less important than horizontal diffusion. This combination of parameters means the vertical and horizontal movement of nitrate is accomplished primarily by diffusive rather than advective processes.

Figure 29 is the vertical nitrate profile generated by a southwesterly wind and the above parameters. One can see that the horizontal stratification increases greatly as one moves inshore. This is because the horizontal stratification parameter; $\alpha_{1}$, is equal to two. That is, the horizontal stratification of nitrate goes as a square law. At the outer edge of the system, the vertical profile and overall concentrations appear to agree with field data; however, this agreement disappears the further inshore one moves.

\section{Mdvectively-Diffusivcly Balanced System}

'The value chosen for the advective and diffusive parameters, for this case, is 0.1 . This value indicates that vertical diffusion and horizontal diffusion are sma11, but vertical diffusion is less important than horizontal diffusion and advection is sma11 compared to horizontal diffusion. 'Thus, the system is weakly dominated by horizontal diffusion. 


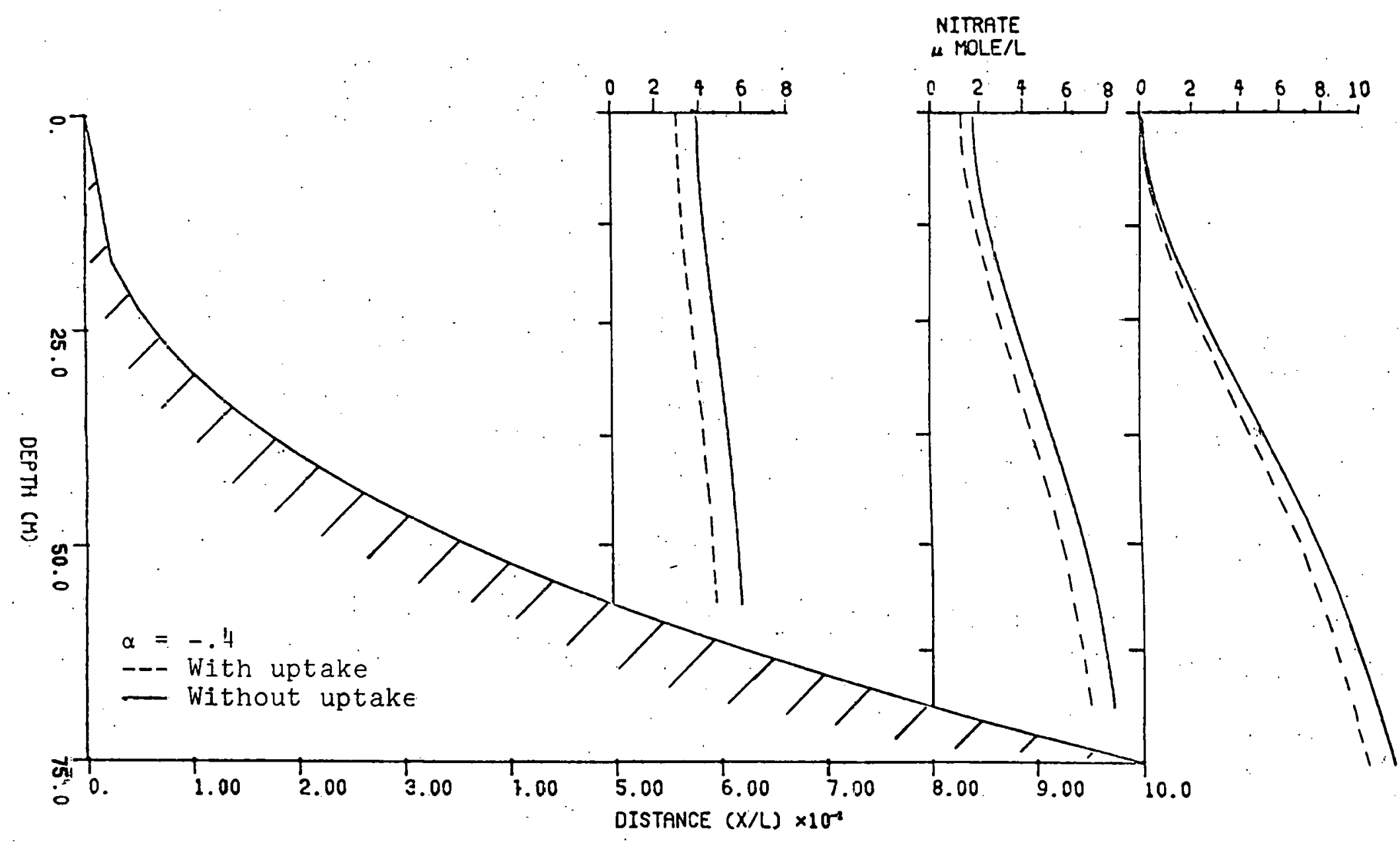

Figure 29. Diffusively dominant system 
Figure 30 shows the nitrate profile generated by a southwesterly wind and the above parameters. These curves show low concentrations of nitrate throughout the system. The general shape of the curve is correct; however, the concentrations are a bit on the low side. This may indicate that horizontal diffusion is important in distributing nitrate, but advection is necessary to both supply and redistribution of the nitrate.

Advection and Horizontal Diffusion

for this case, the following values were chosen for the characteristic magnitudes: $\frac{\psi_{\mathrm{L}} \mathrm{L}}{\mathrm{D}_{\mathrm{L}} h_{\mathrm{L}}}=1$ and $\frac{\mathrm{D}_{\mathrm{V}} \mathrm{L}^{2}}{\mathrm{D}_{\mathrm{L}} \mathrm{h}_{\mathrm{L}}^{2}}=.1$. The small number for the second coefficient indicates that vertical diffusion is small relative to horizontal diffusion and the value for the advection term indicates that horizontal diffusion is of the same order as advection. This combination of parameters means, for this system, nitrate is moved about by horizontal diffusion and advection and the upward propagation of nitrate is accomplished by vertical advection rather than diffusion.

Figures 31 and 32 are the vertical nitrate profiles generated by a southwesterly wind with the above advection and diffusion parameters. Both graphs show low surface concentrations of nitrate and an increased nitrate concentration near the bottom. This agrees with field data. 'lhe dashed line indicates the vertical nitrate profile obtained when a phytoplankton nutrient uptake term was added. The addition of this term results in an overall decrease in nitrate, which is to be expectcd since uptake by phytoplankton serves as a sink in the system and is held constant throughout the water column. 


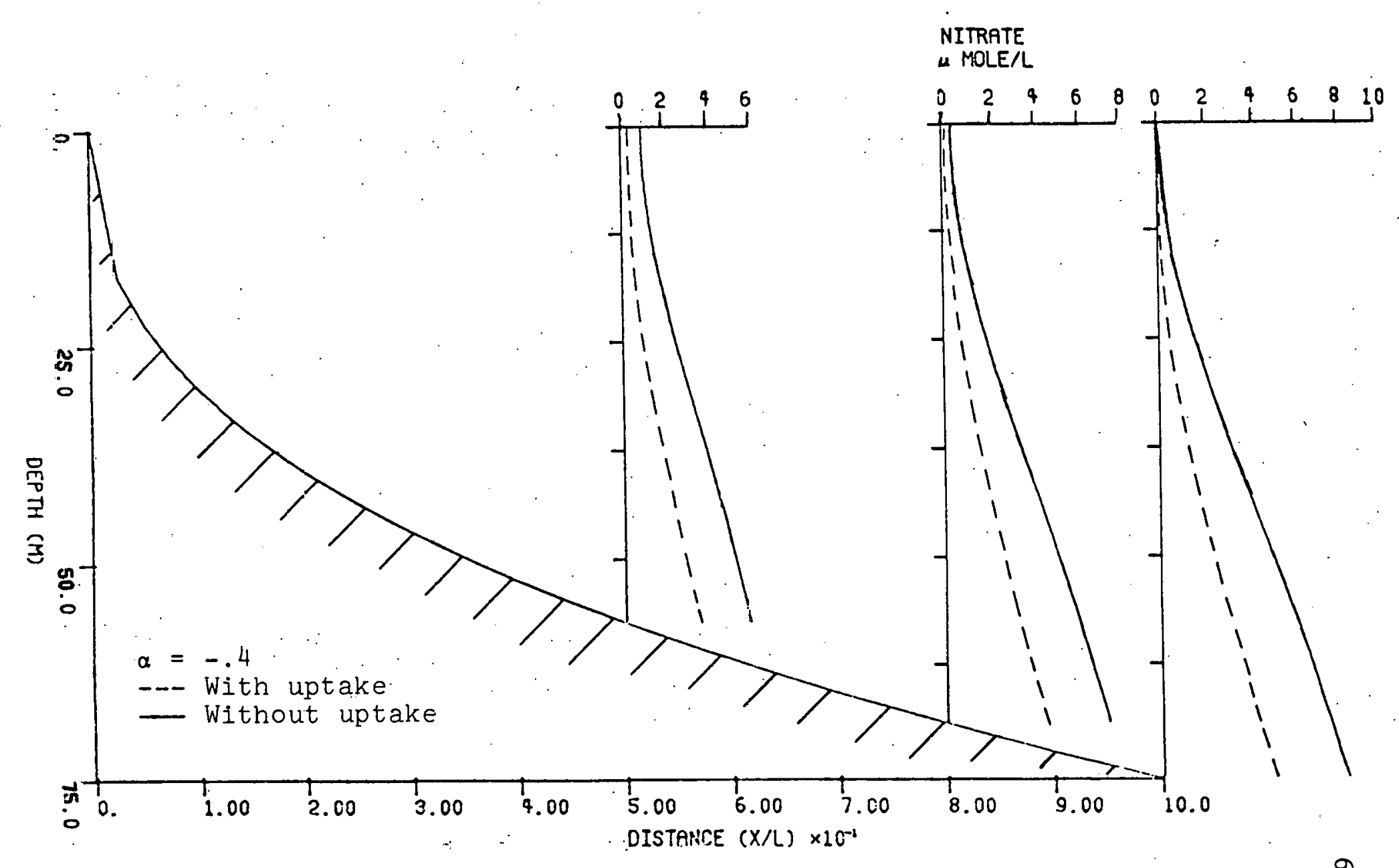

Figure 30. Advectively-diffusively balanced system 
NITRATE

omole/l

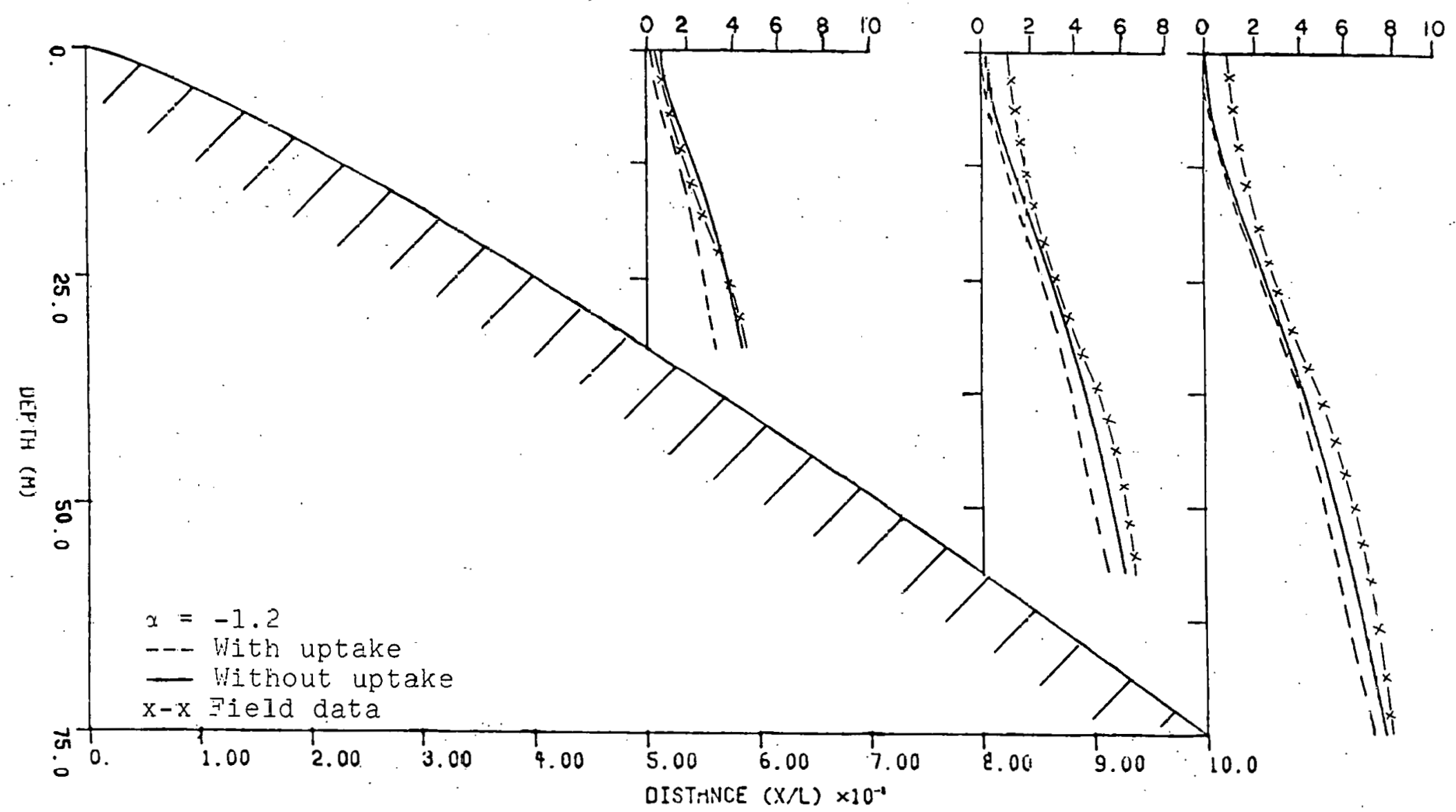

Figure 31. Advection ard horizontal diffusion with a southwesterly wind 


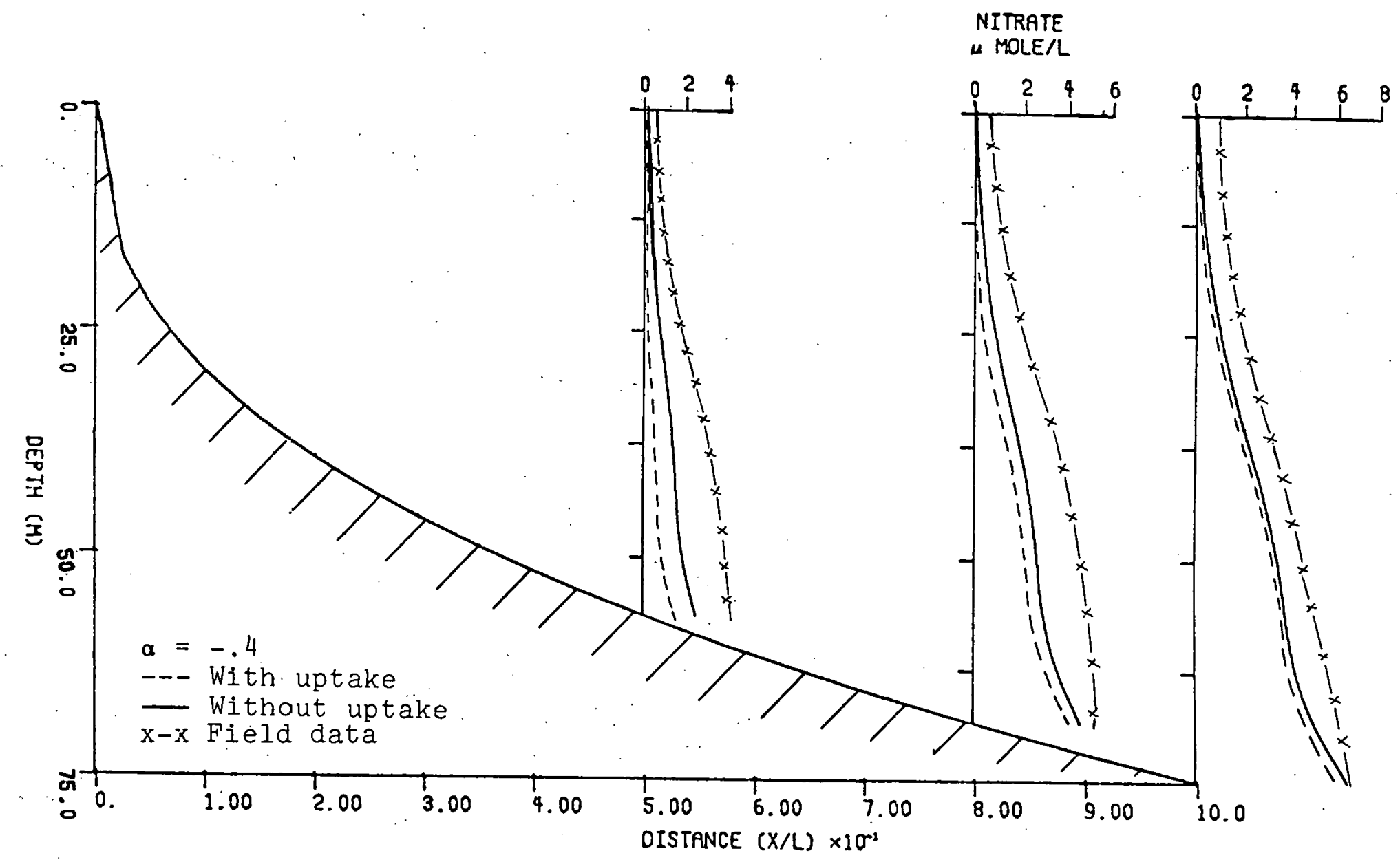

Figure 32. Advection and horizontal diffusion with a southwesterly wind and different bottom profile 
In Figure 32 the similarity parameter describing the bottom profile has been changed and it is apparent that bottom topography has an effect on nitrate distribution; $\underline{i}$.e. , the system can feel the bottom in an advective-diffusive manner. The bottom effect is introduced from the terms $D_{x} \frac{\partial^{2} N}{\partial x^{2}}, \frac{\partial D_{x}}{\partial x} \frac{\partial N}{\partial x}$ and $u \frac{\partial N}{\partial x}$. In this case, $\alpha_{1}=1.61$ and $\alpha=-.4$.

These two graphs show an increase of nitrate beginning at approximately 5-10 meters. This is not in agreement with field data and $1 \tau$ is thought to be an artifact resulting from a steady-state system.

Figures 33-37 are the nitrate profiles generated by northeasterly, southeasterly, northwesterly and easterly winds. Again, the broken line indicates the nitrate profile generated after an uptake term has been added. The values for the respective magnitudes are still 1 and .1 .

Figure 33 is the vertical profile produced by a northwesterly wind. It is readily apparent that this combination of wind and parameters causes a large buildup of nitrate in the system, starting at the surface. The high surface value and the general shape of the curve are not in agreement with field data. Also, the nitrate concentration increases markedly as one moves shoreward, reaching surface values of approximately $3.5 \mu \mathrm{g}-\mathrm{at} / 1$ of nitrate. This also does not agree with field data. The shoreward increase of nitrate results from the value chosen for $\alpha_{1}$, the horizontal stratificaliun parameter. With $\alpha_{1}$ positive, the horizontal gradients increase shoreward. In this case, $\alpha_{1}=0.92$. The horizontal and vertical velocity profiles (Figure 27) show water being advected into the system in the mid-regions, accompanied by a downwelling process. This combination accounts for the increased nitrate seen at the bottom. 


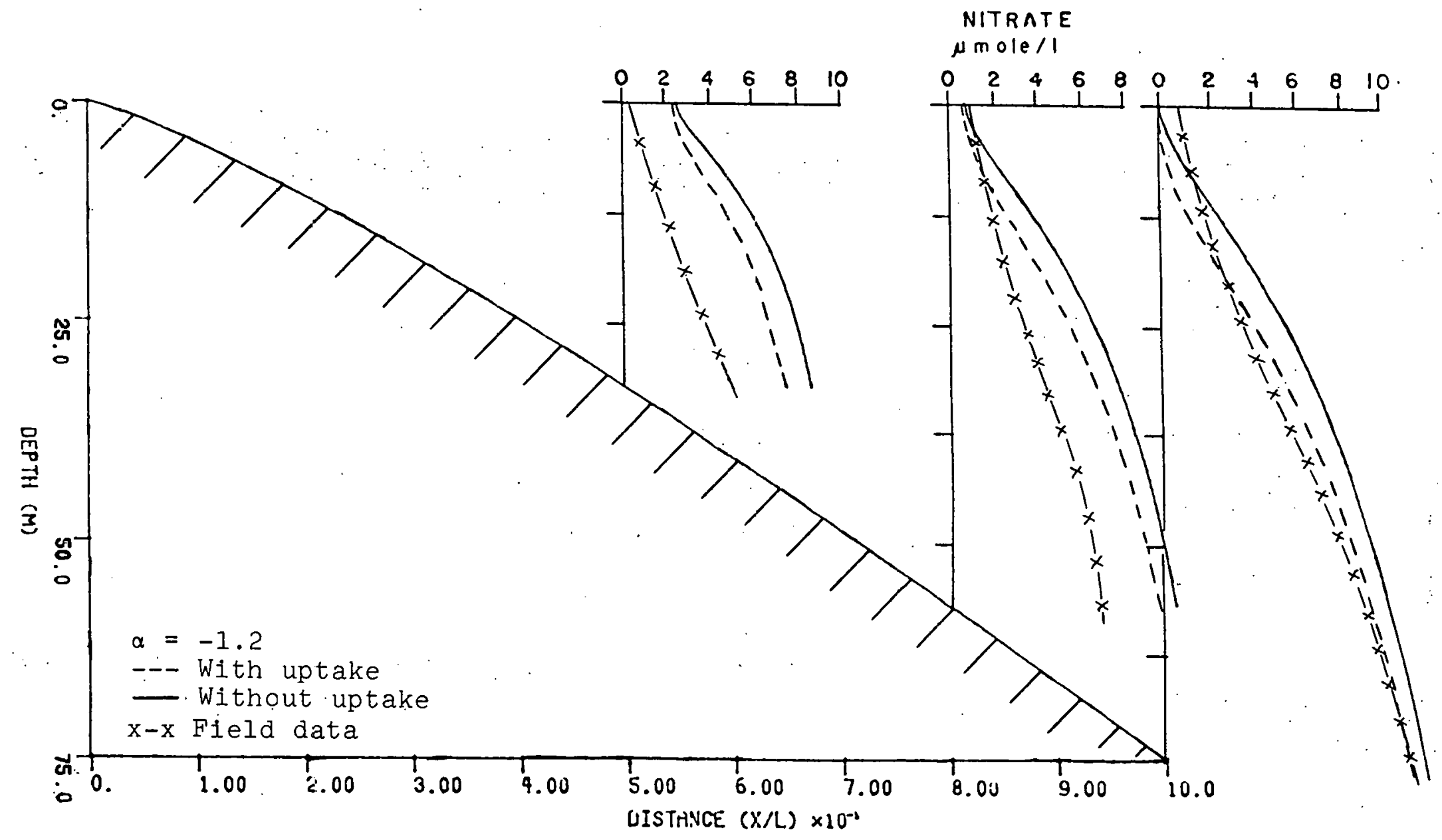

Figure 33. Advection and horizontal diffusion with a northwesterly wind 


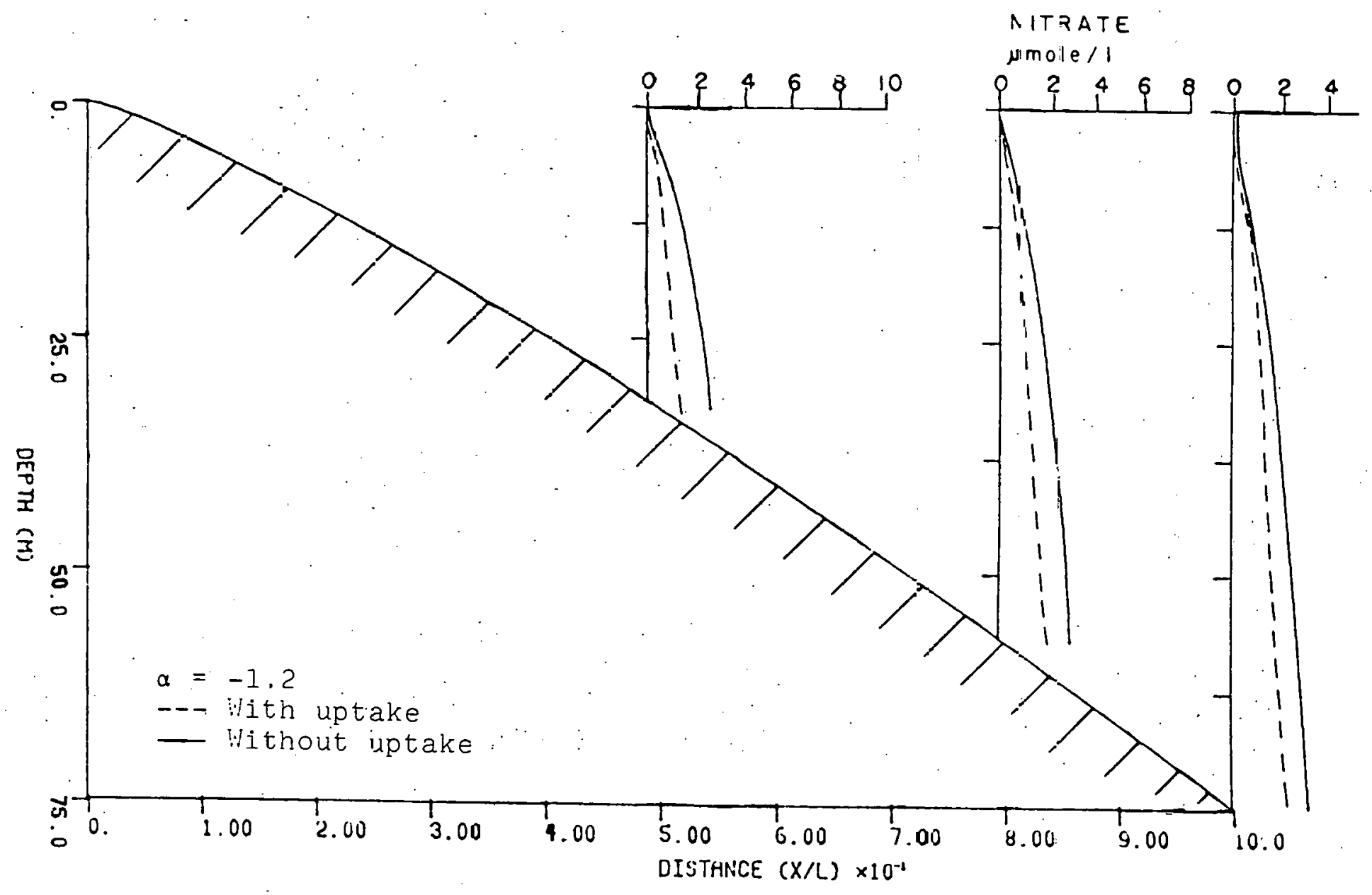

Figure 34. Advection and horizontal diffusion with a southeasterly wind 


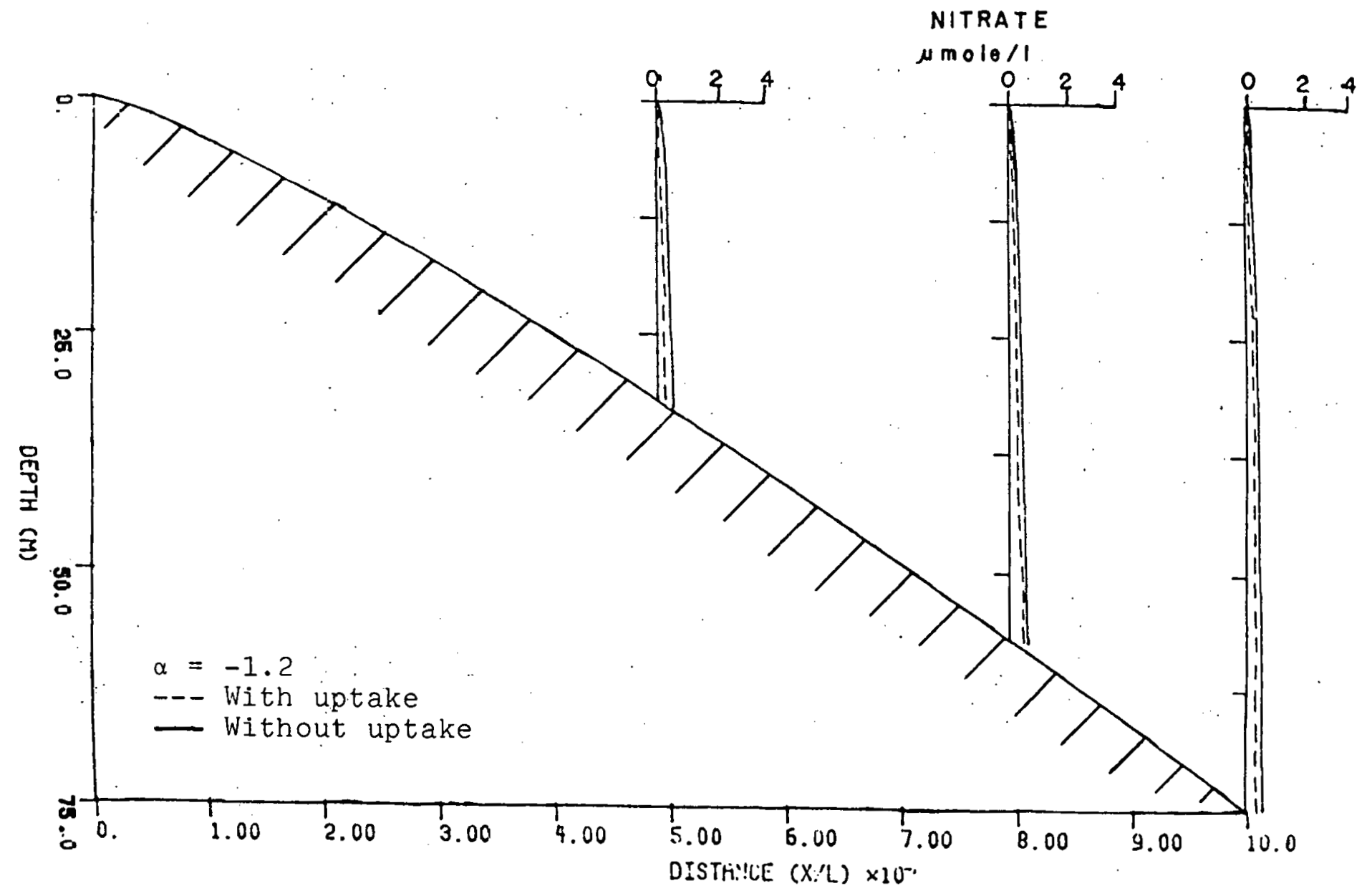

Figure 35. Adrection and horizontal diffusion with a northeasterly wind 


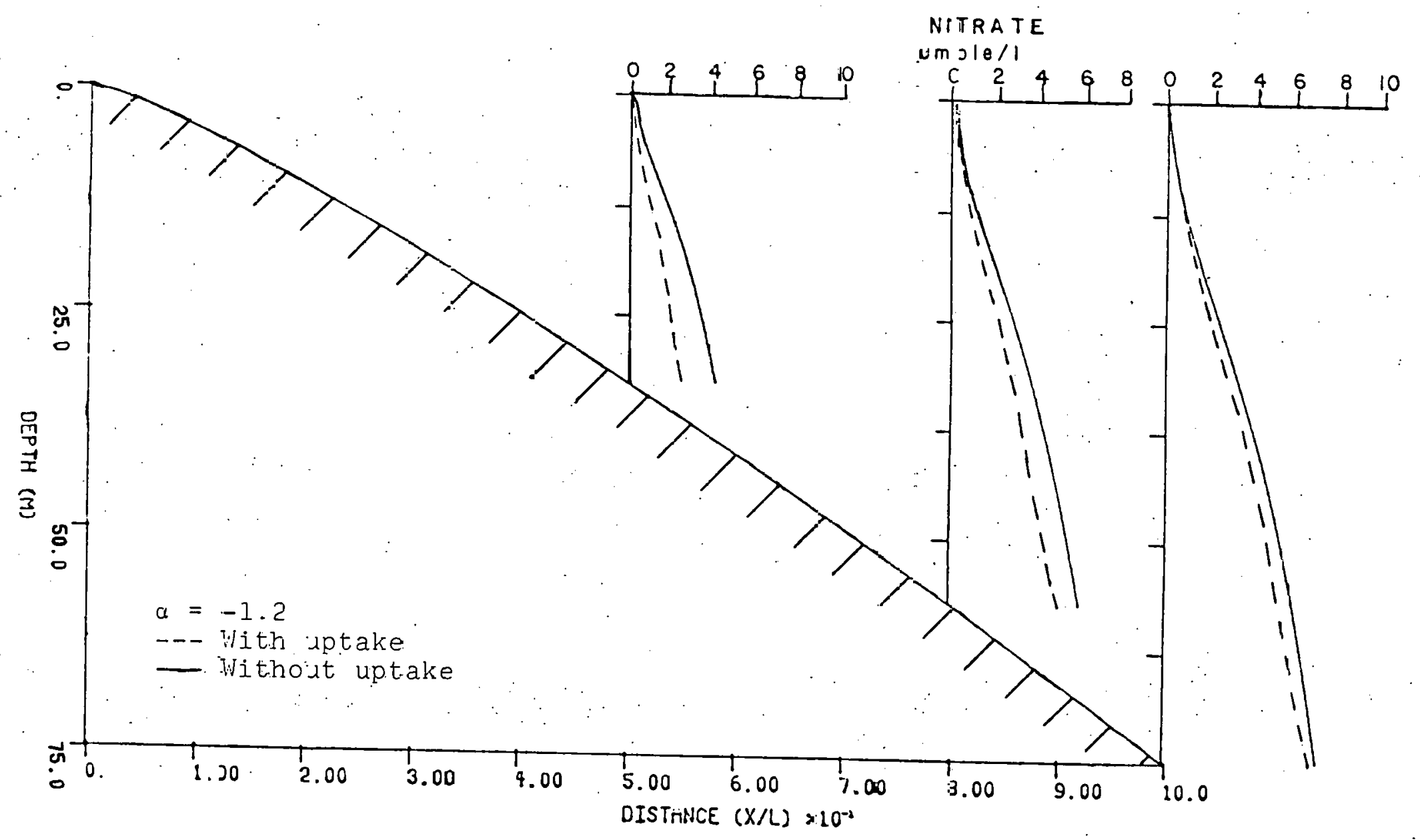

Figure 36. Adrection ard horizontal diffusion witi an easterly wind 


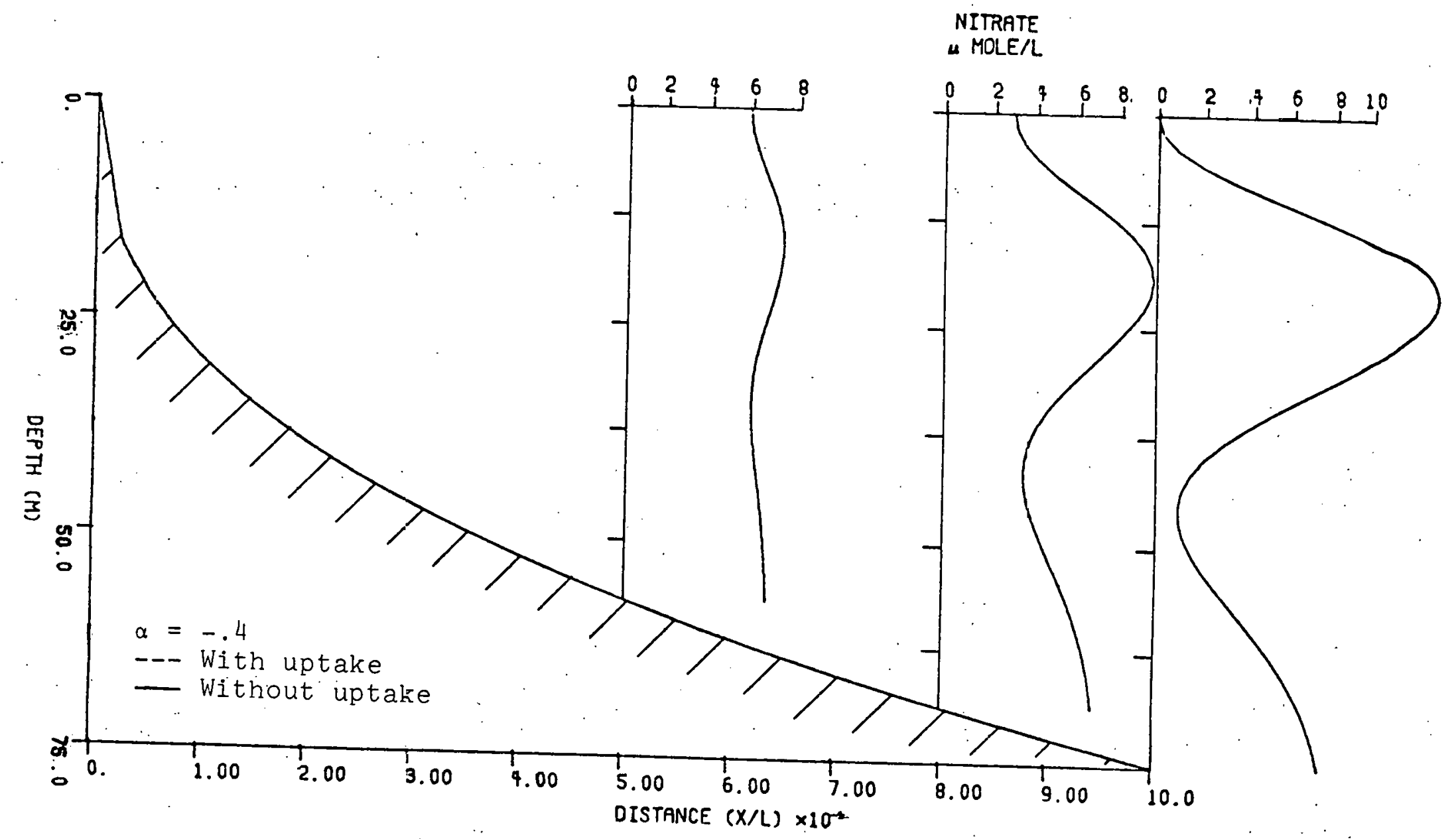

Figure 37. Advection and horizontal diffusion with an easterly wind and different bottom profile 
Figure 34 is the nitrate profile generated by a southeasterly wind. One can see that there is little buildup of nitrate in the system. The introduction of an uptake term again gives an overall decrease in concentration. The surface nitrate value at the more shoreward position is somewhat high for a surface concentration and this again comes from the horizontal stratification parameter.

The vertical nitrate profile generated by a northeasterly wind is shown in Figure 35. It is apparent that a wind from this direction causes almost no increase of nitrate and the introduction of a nitratc uptake term appears to have very little effect. As one would expect, a northeasterly wind sets up an Ekman transport offshore such that surface waters are deflected onshore and bottom waters are deflected offshore. This type of transport does not allow for the introduction of nutrientrich waters.

Figures 36 and 37 are the nitrate profiles that result when an east wind is applied to the system. Figure 36 shows the profile generated with and without uptake values. This graph shows the same general curve produced by southwesterly winds; however, the effect of nutrient uptake is not as pronounced with an east wind.

In Figure 37 the similarity parameter describing the bottom has been changed. All other parameters remained the same. This combination allows horizontal diffusion to become very strong, which produces a maximum nitrate concentration in the upper layer. As one moves shoreward, a well mixed system with high nitrate values is observed. This is due to $\alpha_{1}$, the horizontal stratification parameter. 


\section{Varying Bottom Topography}

Figures 38-40 show the effect of changing bottom topography on the

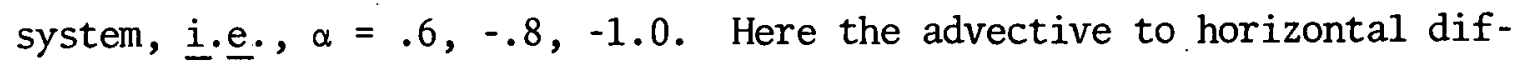
fusion mixing ratio is equal to one and the diffusive mixing scales ratio is equal to .5. The graphs also show the effect of nutrient uptake.

As alpha becomes more positive, the nitrate curves and concentration values show more agreement with field data. Having alpha more positive results in a maximum nitrate value near the bottom, whereas, the other bottom values give nitrate distributions that appear to have an essentially linear relationship with depth. As previously mentioned, the bottom effect is introduced through the terms $D_{x} \frac{\partial^{2} N}{\partial x^{2}}, \frac{\partial D_{x}}{\partial x} \frac{\partial N}{\partial x}$ and $\mathrm{u} \frac{\partial \mathrm{N}}{\partial \mathrm{x}}$ :

\section{Complete System}

Figures 41-43 are the vertical nitrate profiles produced when all of the biological terms are added to Equation(6). The results shown are generated by the same set of parameters and conditions used for Figures 38-40.

Figures 42 and 43 show essentially the same nitrate profiles. It is not until alpha, the bottom offshore attenuation exponent, becomes more positive that the nitrate maximum near the bottom becomes evident.

In Figure 42 there is the beginning of a nitrate maximm near the bottom at the outer edge of the system. As one moves shoreward, the nitrate gradient becomes stronger. Comparison of this figure with Figure 39 indicates that the full biological system is necessary to produce a nitrate curve that agrees with field observations (low surface values and a maximum near the bottom). 


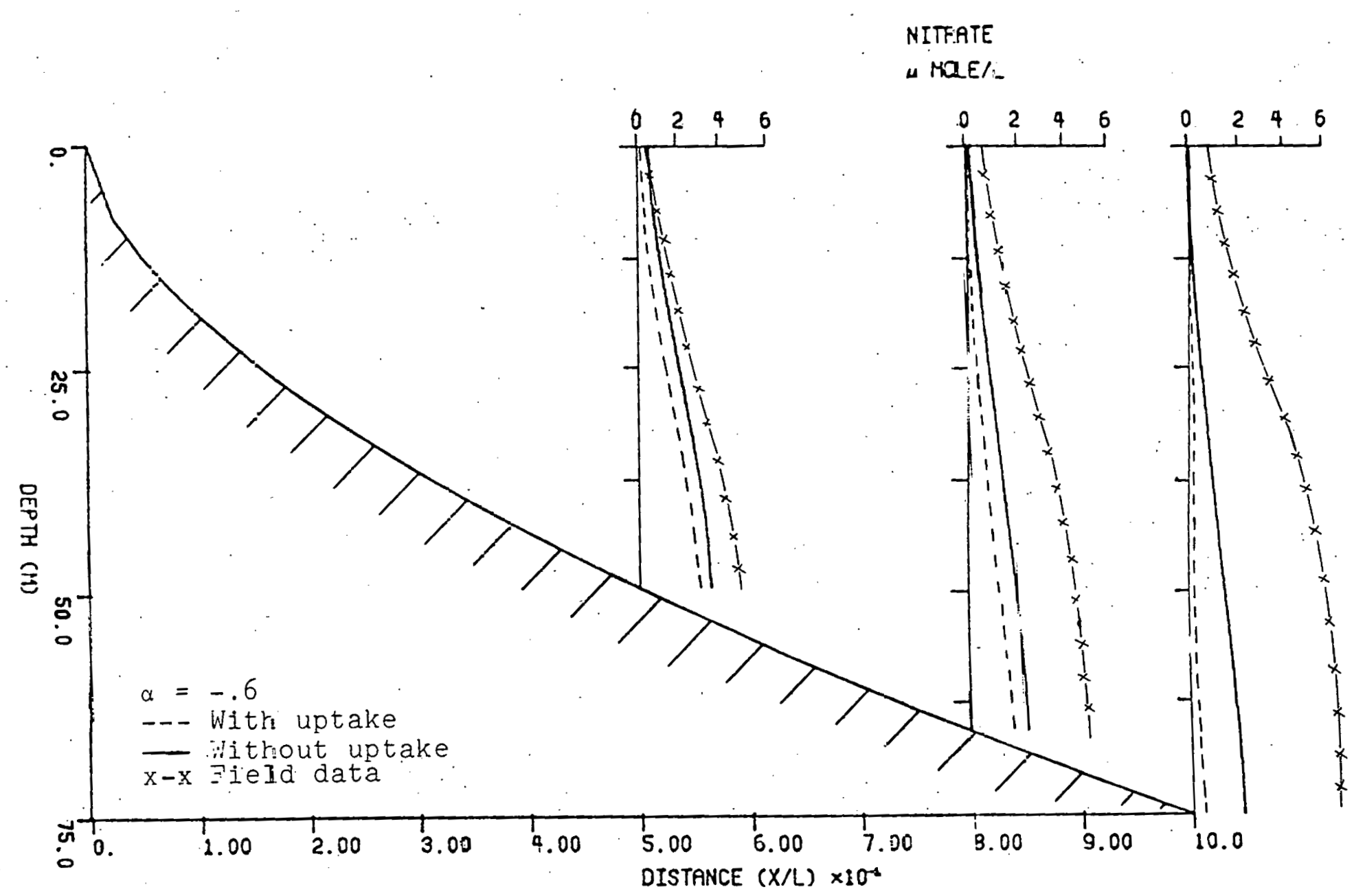

Figure 38. Varying bottom topography, $a=-.6$ 


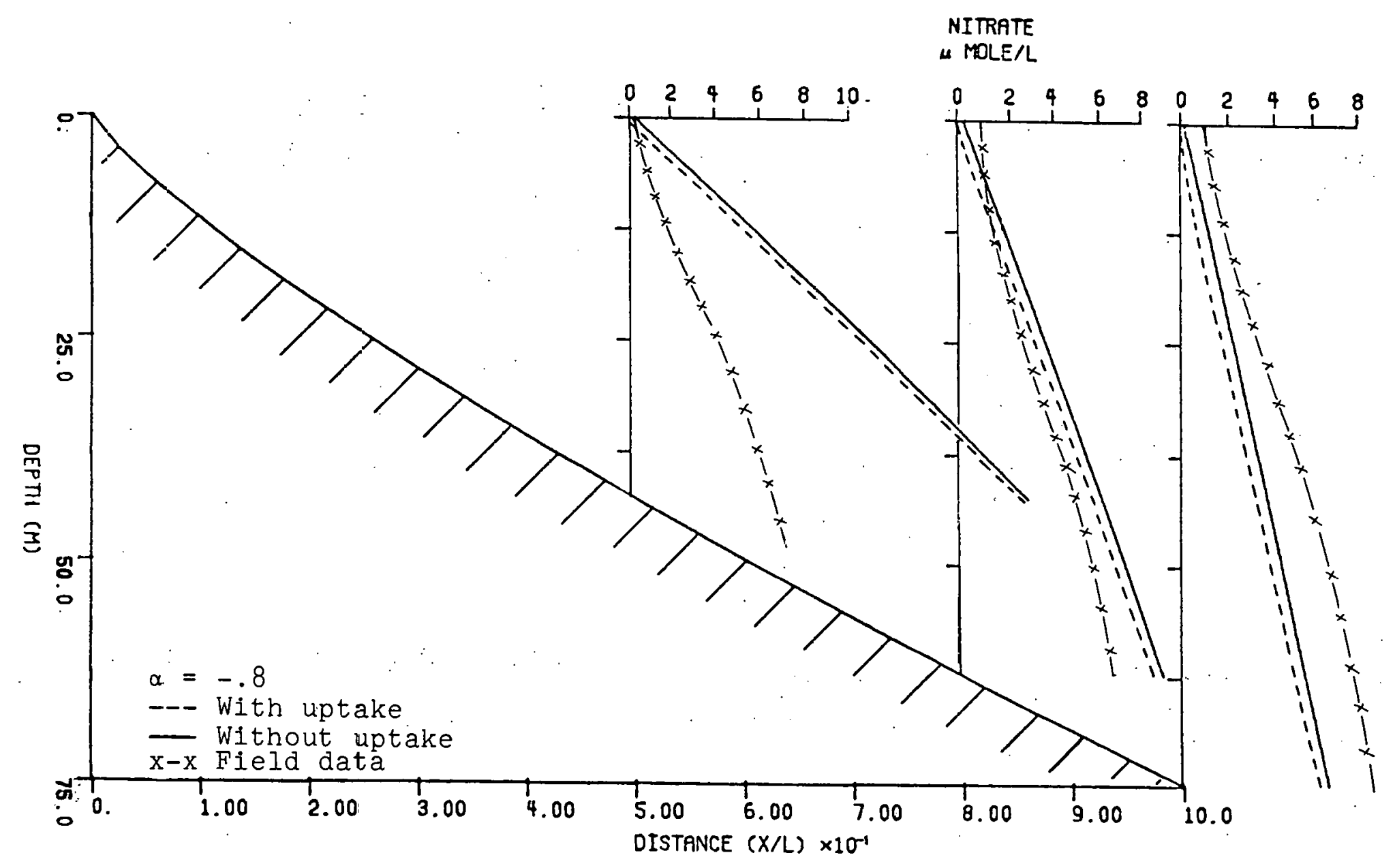

Figure 39. Varying bottom topography, $\alpha=-.8$ 


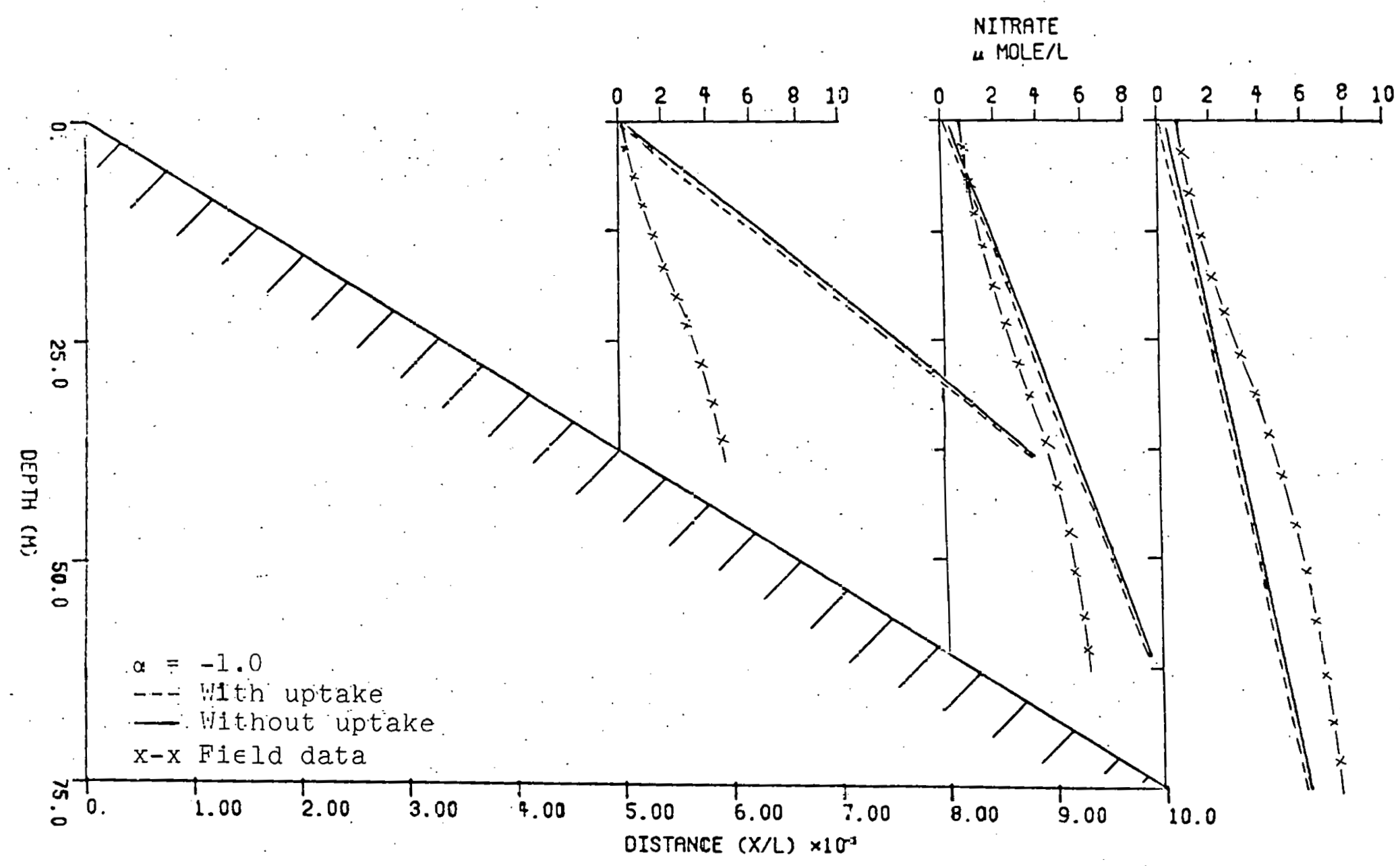

Figure 40. Varying bottom topography, $a=-1.0$. 


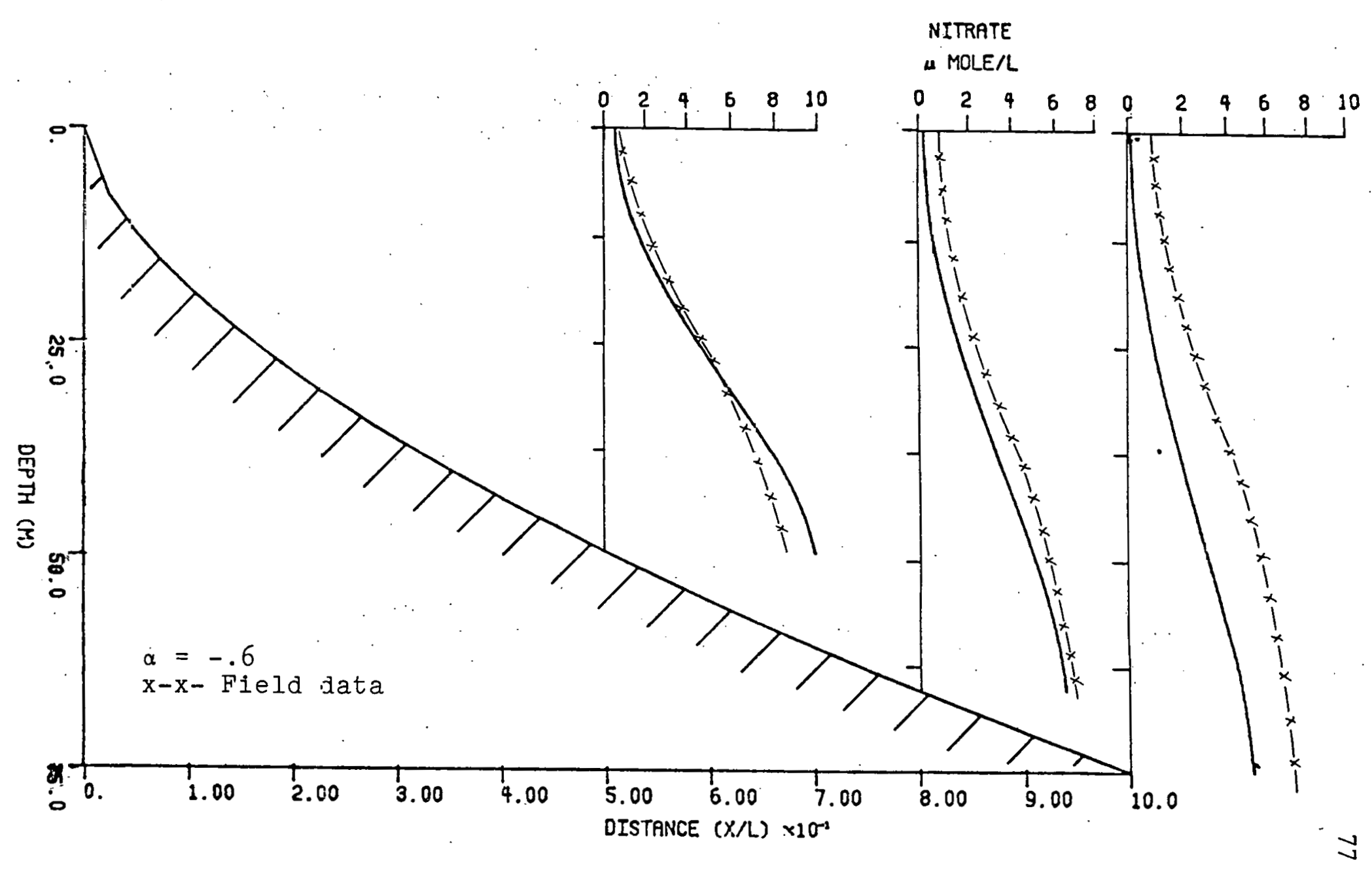

Figure 41. Complete system with $\alpha=-.6$ 


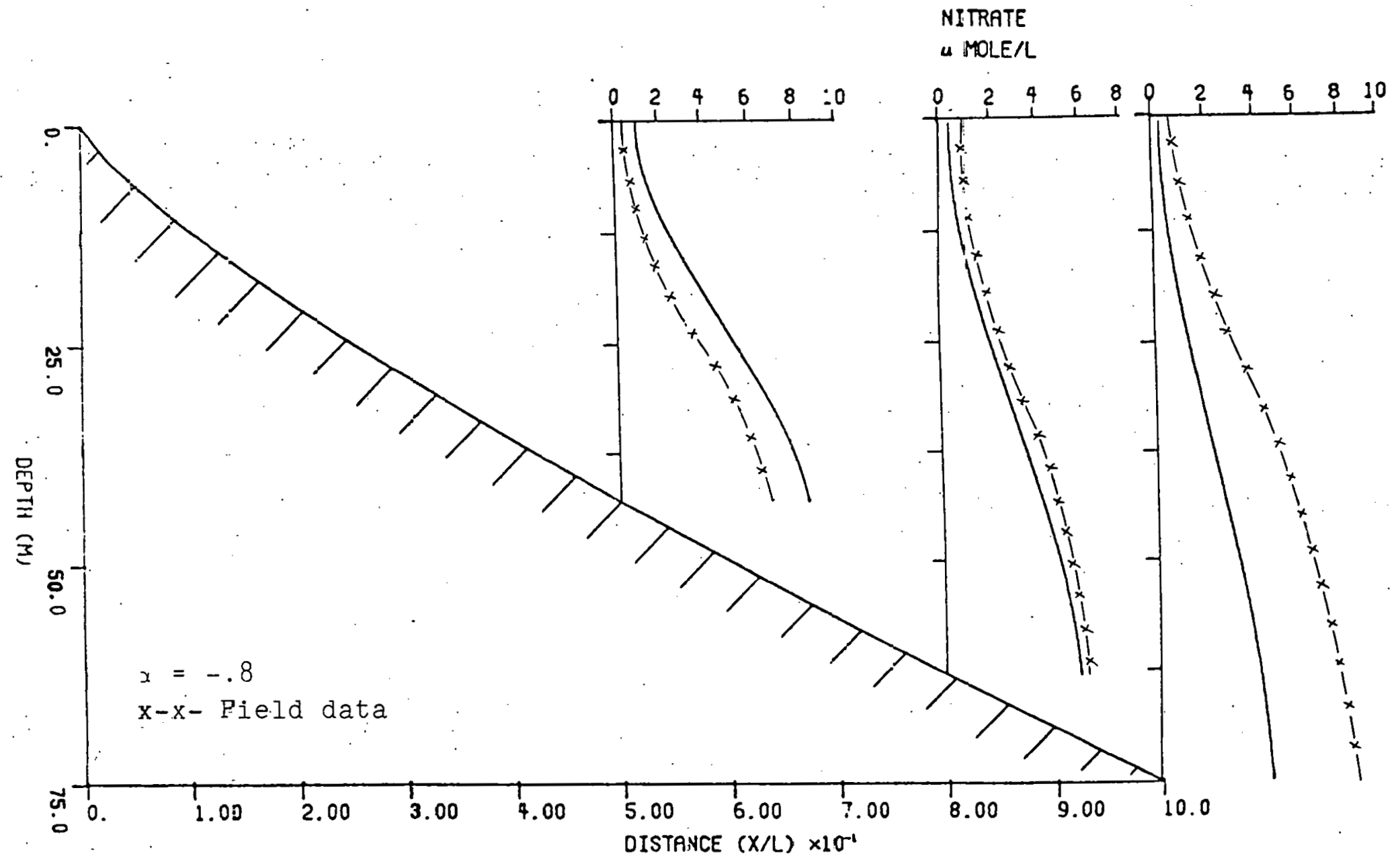

Figure 42. Complete system witt $\alpha=-.8$ 


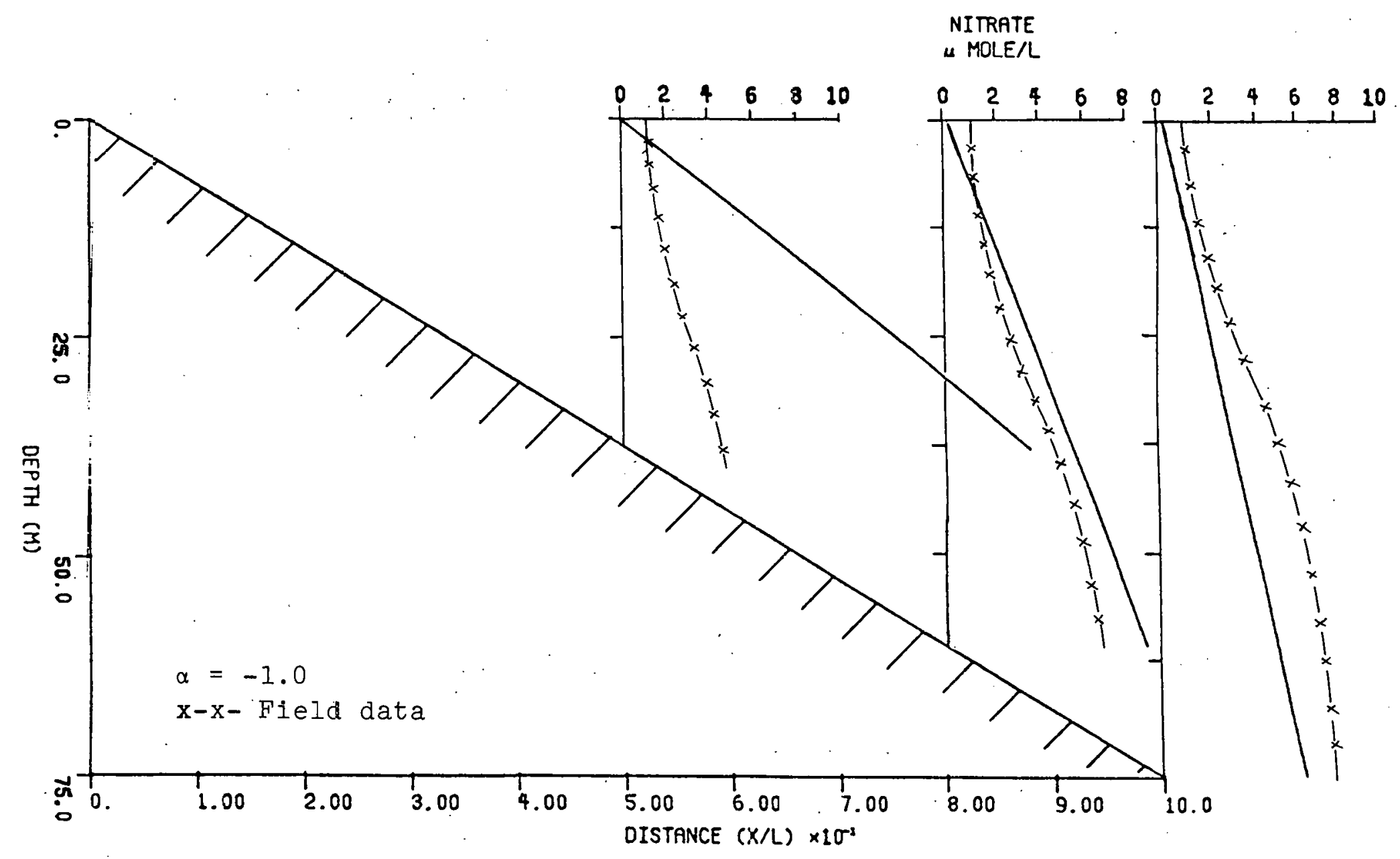

Figure 43. Complete system with $\alpha=-1.0$ 
Figure 41 shows the nitrate distribution that is most realistic. This profile has low surface values and a nitrate maximum near the bottom. Also, the gradients are increasing as one moves shoreward; which causes the nitrate maximun to become stronger. Comparison with Figure 38 shows that the inclusion of the biological terms results in higher nitrate values. Also, comparison of this bottom profile $(\alpha=-.6)$ to the actual bottom profile for Onslow Bay (Figure 44) shnws the two to bc somewhat similar. This points out that bottom topography is important in coastal areas. 


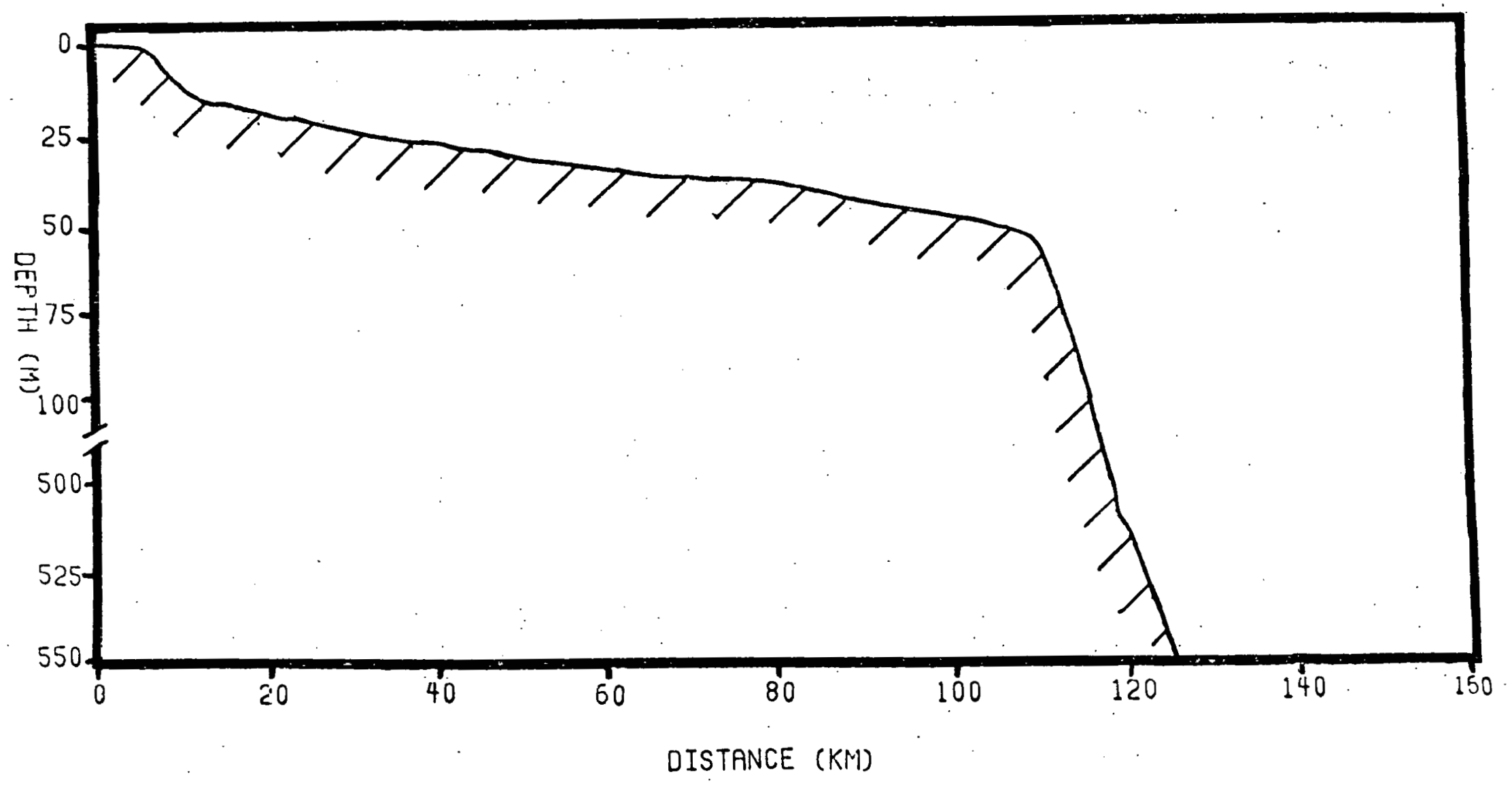

Figure 44. Bottom profile of Onslow Bay 
CHAPTER X

CONCLUSION

A two-dimensional steady-state model of nitrate distribution during an intrusion has been developed. This model incorporates physical, biological and chemical components of the marine ecosystem. A circulation pattern resembling that of an intrusion was used to advect and diffuse the nitrate about in the system. The technique used to construct the model is new to ecological modelling and using this techulique, it has been possible to generate vertical and horizontal nitrate profiles that coincide with field observations. Thus, it is reasonable to conclude that primary production in Onslow Bay can be controlled by periodic inputs of $\mathrm{No}_{\mathrm{S}}$ from sub-surface GSW.

The major weakness of this model is the lack of knowledge of correct expressions and parameter values which describe the real world and all its complexities. However, using what is known and extrapolating from this, the model gives reasonable nitrate values and allows one to determine which processes are of importance. It, alsn pnintis nut. the fact that the , physical and biological processes in an intrusion are not independent of edch ulner.

The effect of bottom topography, which primarily affects the flow velocities, is shown to have an important secondary effect on the distribution of nitrate. When $\alpha$, the bottom similarity aticniation exporient, is equal to -.6 , the nitrate profile generated is sijilar to that seen in field data. This bottom profile resembles the bottom profile for Onslow Bay .

Two parameters were introduced which are the ratio of advection to 
horizontal diffusion and the ratio of vertical to horizontal diffusive mixing time scales. By comparing model results to field data, ranges of reasonable values for the ratios can be determined, which can give an indication of the most important processes in coastal shelf waters. These are order of magnitude estimates rather than precise constants. This model is appreciated as being a first attempt but it does establish some criteria for further research. Future work includes adding another spatial dimension and making the model time dependent. Also, the biological terms should be made functions of the nondimensional parameters $n$ and $\xi$. This would allow the biological processes to vary in the $x$ and $z$ directions instead of remaining as constants. This addition would increase the realism of the resutts generated by the model.

The technique employed in this model offers the modeler a flexibility that previous models have lacked. The main strength of this model is that it may be used to look at the distribution of any variable that does not directly affect the circulation. 


\section{LIST OF REFERENCES}

Baylor, E. R. and W. P. Sutcliffe, Jr. 1963. Dissolved organic matter in seawater as a source of particulate food. Limnol. Oceanog. 8: 369-371.

Blanton, J. O. 1971. Exchange of Gulf Stream water with North Carolina shelf water in Onslow Bay during stratified conditions. Deep-Sea Res. 18:167-178.

Brett, J. P. and C. A. Zala. 1975. Daily pattern of nitrngen excretion and oxygen consumption of Sockeye Salmon (Oncorhynchus nerka) under controlled conditions. J. Fish. Res. Board Can. 32(T2):2479'-2488.

Bumpus, D. F. 1955. The circulation over the continental shelf south of Cape Hatteras. Trans. Amer. Geophys. Un. 36(4):601-611.

Bumpus, D. F. and E. L. Pierce. 1955. The hydrography and distribution of Chaetognaths over the continental shelf of North Carolina. Pap. Mar. Bio1. and Oceanogr. Supp1. Deep-Sea Res. 3:92-109.

Bunt, J. S., K. E. Cooksey, M. A. Heeb, C. C. Lee and B. F. Taylor. 1970. Assay of algal nitrogen fixation in the marine subtropics by acetylene reduction. Nature (London) 227:1163-1164.

Carpenter, E. J. 1973. Nitrogen fixation by Oscillatoria (Trichodesmium) thiebautii in the southwestern Sargasso Sea. Deep-Sea Res. 20:285288 .

Carpenter, E. J. and J. J. MCCarthy. 1975. Nitrugen fixitiun and uptake uf cunbined nilıugenüs nutrients by üsillatoria (Trichodc mium) thiehautii in the western Sargasso Sea. Limnol. Oceanog. 20:389401.

Collatz, L. 1960. The Numerical Treatment of Differential Lquations, Third edition. Springer-Verlag, Berlin.

Corner, E. D. S. and A. G. Davies. 1971. Plankton as a factor in the nitrogen and phosphorus cycles in the sea. Adv. Mar. Biol. 9:101204.

Corner, E., D. S. and B. S. Newe11. 1967. On the nutrition and metabolism of zooplankton. IV. The forms of nitrogen excreted by Calanus. J. Mar. Bio1. Ass. U. K. 47:113-120.

Cushing, D. H. 1969. Morning Review Lectures of the Int. Oceanogr. Congr., Second, UNESCO, Paris, pp. 103-115.

Dugdale, R. C. 1967. Nutrient 1imitations in the sea: Dynamics, identification and significance. Limnol. Oceanogr. 12:685-695. 
LIST OF REFERENCES (continued)

Dugdale, R.C. and J.J. Goering. 1967. Uptake of new and regenerated nitrogen in primary productivity. Limnol. Oceanogr. 12:196-206.

Dugdale, R.C., J.C. Goering and J. H. Ryther. 1964. High nitrogen fixation rates in the Sargasso Sea and the Arabian Sea. Iimnol. Oceanogr. 9:507-510.

Dugdale, R.C., D.W. Menzel and J.H. Ryther. 1961. Nitrogen fixation in the Sargasso Sea. Deep-Sea Res. 7:298-300.

Dunstan, W.M. and L.P. Atkinson. 1976. Sources of New Nitrogen for the South Atlantic Bight. Estuarine Processes. 1:69-78.

Ekman, V.W. 1905. On the influence of the earth's rotation on ocean currents. Ark. f. Mat., Astron. Och Fysik 2(11):1-53.

Eppley, R.W. and J. L. Coatsworth. 1968. Nitrate and nitrite uptakes by Ditylum brightwellii: Kenetics and mechanisms. J. Phycol. $4: 151-156$.

Eppley, R.W., J. L. Coatsworth and L. Solorzano. 1969. Studies of nitrate reductase in marine phytoplankton. Limnol. Oceanogr. 14:194-205.

Eppley, R.W., J.N. Rogers and J.J. McCarthy. 1969. Half saturation constants for uptake of nitrate and ammonia by marine phytoplankton. Limnol. Oceanogr. 14:912-920.

Fogg, G.E. 1966. The extracellular products of algae. Oceanogr. Mar. Biol. Ann. Rev. 4:195-212.

Ford, W.L., J.R. Longard and R.E. Banks. 1952. On the nature, occur rence and origin of cold low salinity water along the edge of the Gulf Stream. J. Mar. Res. 11:281-293.

Ford, W.L. and A.R. Miller. 1952. The surface layer of the Gulf Stream and adjacent waters. J. Mar. Res. 11:267-280.

Fuglister, F.C. 1951. Multiple arrents in the Gulf Stream. Tellus $3(4): 230-233$.

Gerking, S.D. 1962. Production and food utilization in a population of Bluegill Sunfish. Ecol. Monogr. 32:31-78.

Goering, J.J., R.C. Dugdale and D.W. Menzel. 1966. Estimates of $\operatorname{tn}$ situ rates of nitrogen uptake by Trichodesmium in the tropical Atlantic Ocean. Limnol. Oceanogr. 11:614-620.

Hansen, A.G. 1964. Similarity Analyses of Boundary Value Problems in Engineering. Prentic Hall, Inc., Englewood Cliffs, New Jersey, p. 114. 


\section{LIST OF REFERENCES (continued)}

Harris, E. 1959. The nitrogen cycle in Long Island Sound. Bull. Bingham Oceanogr. Coll. 17:31-65.

Harris, E. and G. A. Riley. 1956. Oceanography of Long Island Sound-1952-1954. VIII. Chenical composition of the plankton. Bull. Bingham Oceanogr. Col1. 15:315-323.

Iselin, C. O'D. and F. C. Fuglister. 1948. Some recent developments in the study of the Gulf Stream. J. Mar. Res. 17:317 329.

Jorgensen, C. B. 1966. Biology of Suspension Feeding. Fergamon Fress, London.

Lassister, $\dot{R}$. R. 1975. Mudelling dynamics of biological and chemical components of aquatic ecosystems. Ecological Research Series, EPA-660/3-75-012.

Lehman, J. T., D. B. Botkin and G. E. Likens. 1975. The assumptions and rationales of a computer model of phytoplankton dynamics. Limnol. Oceanogr. 20:343-364.

Lotka, A. J. 1925. Elements of Physical Biology, The Williams and Wilkins Company, Baltimore.

Mague, T. H., N. M. Weare and O. Holm-Hansen. 1974. Nitrogen fixation in the North Pacific Ocean. Mar. Biol. 24:109-119.

MacFadyen, A. 1964. Energy flow in ecosystems and its exploitation by grazing, pp. 145-167. In D. Crisp (ed.), Grazing in lerrestrial and Marine Environments, Blackwell Ltd., Oxford.

MacIssac, J. J. and .R. C. Dugdale. 1969. The kinetics of nitrate and ammonia uptake by natural populations of marine phytoplankton. Deep-Sea Kes. 16:415-422.

MacIssac, J. J. and R. C. Dugdale. 1971. Interactions of light and inorganic nitrogen in controlling nitrogen uptake in the sea. Deep-Sea Res. 29:280-329.

Monod, J. 1942. Recherches sur 1a Croissance des Cultures Bacteriennes, Hermann, Paris, p. 211.

Mortimer, C. H. 1941. The exchange of dissolved substances between mud and water in lakes. J. Ecol. 29:280-329.

Mortimer, C. H. 1942. The exchange of dissolved substances between mud and water in lakes: III and IV, summary and references. J. Ecol. 30:147-201. 


\section{LIST OF REFERENCES (continued)}

O'Brien, J. J. and J. S. Wroblewski. 1973. A simulation of the mesoscale distribution of the lower marine trophic levels off west Florida, Ch. 3. In B. Patten (ed.), Systems Analysis and Simulation in Ecology, Vol. 4.

Odum, E. P. 1962. Relationships between structure and function in the ecosystem. Jap. J. Ecol. 12:100-118.

Odum, H. T. 1957. Trophic structure and productivity of Silver Springs, Florida. Ecol. Monogr. 27:55-112.

Paffenhöfer, G.-A. and J. D. H. Strickland. 1970. A note on the feeding of Calanus helgolandicus on detritus. Mar. Biol. 5:97-99.

Patten, B. C. 1968. Mathematical models of plankton production. Int. Rev. ges. Hydrobiol. 53(3):357-408.

Pietrafesa, L. J: 1973. Steady baroclinic circulation on a continental shelf. Ph.D. dissertation, Department of Oceanography and Geophysics Group, University of Washington, Seattle. University Microfilms, Ann Arbor, Michigan.

Pietrafesa, L. J. and L. P. Atkinson. 1976. Continental shelf processes affecting the oceanography of the South Atlantic Bight; a research proposal submitted to Energy Research and Development Administration requesting renewal of Contract. E(38-1)902.

Pietrafesa, L. J., D. A. Brooks, L. P. Atkinson, R. D'Amato and J. Bane. 1975. Preliminary data report, physical/dynamical observations made in Onslow Bay; summer, fall and winter 19.75. Center for Marine and Coastal Studies, North Carolina State University, Raleigh.

Poulet, S. A. 1976. Feeding of Pseudocalanus minutus on living and nonliving particles. Mar. Biol. 34:117-125.

Rittenberg, S. C., K. O. Emery and L. Orr Wilson. 1955. Regeneration of nutrients in sediments of marine basins. Deep-Sea Res. 3:23-45.

Rowe, G. T., C. H. Clifford, K. L. Smith and A. L: Hamilton. 1975. Benthic nutrient regeneration and its coupling to primary productivity in coastal waters. Nature 255:215-217.

Ruzecki, E. P. 1974. A socio-economic environmental baseline summary for the South Atlantic region between Cape Hatteras, North Carolina and Cape Canavera1, Florida, Vol. II--Climatology. Bureau of Land Management, United States Department of Interior, Council on Environmental Quality, Washington. 
LIST OF REFERENCES (continued)

Savitz, J. 1971. Nitrogen excretion and protein consumption of Bluegill Sunfish. J. Fish. Res. Board Can. 28:449-451.

Scheid, F. 1968. Schaum's Outline of Theory and Problems of Numerical Analysis, McGraw-Hill Book Company, New York, p. 422.

Smith, H. W. 1929. The excretion of ammonia and urea by the gills of fish. J. Biol. Chem. 81:727-747.

Stefansson, U., L. P. Atkinson and D. Bumpus. 1971. Hydrographic properties and circulation of the North Carolina shelf and slope waters. Deep-Sea Res. 18:383-420.

Struhsaker, P. 1969. Demersal fish resources: Composition, distribution and commercial potential of the continental shelf stocks of southeastern United States. Fish. Inds. Res. 4(7):261-300.

Thomas, W. H. 1971. Effect of ammonium and nitrate concentration on chlorophyll increases in natural tropical Pacific phytoplankton populations. Limnol. Oceanogr. 15:386-394.

Thomas, W. H. and A. N. Dodson. 1968. The effects of phosphate concentration on cell division rates and yield of a tropical oceanic diatom. Biol. Bull. 134:199-208.

Volterra, V. 1927. Sulle fluttuazioni biologiche. Atti. R. Accad. Naz. Lincei. Rend. Cl. Sci. Fis. Mat. e Nat. 5(1):3-10.

Volterra, V. 1927a. Leggi delle fluttuazioni.biologiche: Atti. R. Accad. Naz. Lincci. Rend. Cl. Sci. Fis. Mat. e Nat. 5(1):61-67.

von Arx, W. S., D. F. Bumpus and W. S. Richardson, 1955. On the fine structure of the Gulf Strean front. Deep-Sea Res. 3:46-65.

Webster, F. 1061. A description of Gulf Stream meanders off Onsluw Bay. Deep-Sea Res. 18:130-143.

Williams, P. J. l.eB. and C. S. Yentsch. 1976. An examination of photosynthetic production, excretion of photosynthetic products, and heterotrophic utilization of dissolved organic compounds with reference to results from a coastal subtropical sea. Mar. Biol. $35: 31-40$.

Wood, J. D. 1958. Nitrogen excretion in some marine teleosts. Can. J. Biochen. and phys. 36:1237-1242. 
APPENDICES 


\section{Appendix A. Computer Program}

This program is a numerical integration of a two-point Boundary Value Problem. It calculates the solution of nonhomogeneous secondorder linear differential equations of the form

$$
Y^{\prime \prime}-P(X)^{*} Y^{\prime}-Q(X) * Y+R(X)=0
$$

(note minus signs) in the interval $\mathrm{X}=\mathrm{A}$ to $\mathrm{X}=\mathrm{B}$ by means of a fourthorder Runge-Kutta integration scheme (Collatz, 1960) and then satisfies the two general boundary conditions of the form

$$
\begin{aligned}
& \mathrm{BC}_{11} \mathrm{Y}(\mathrm{a})+\mathrm{BC}_{12} \mathrm{Y}(\mathrm{b})+\mathrm{BC}_{13} \mathrm{Y}^{\prime}(\mathrm{a})+\mathrm{BC}_{14} \mathrm{Y}^{\prime}(\mathrm{b})=\mathrm{BC}_{15} \\
& \mathrm{BC}_{21} \mathrm{Y}(\mathrm{a})+\mathrm{BC}_{22} \mathrm{Y}(\mathrm{b})+\mathrm{BC}_{23} \mathrm{Y}^{\prime}(\mathrm{a})+\mathrm{BC}_{24} \mathrm{Y}^{\prime}(\mathrm{b})=\mathrm{BC}_{25}
\end{aligned}
$$

where the constants $\mathrm{BC}$ are chosen to give the desired boundary conditions (Scheid, 1968). The integration interval starts at A, ends at $B$ and is divided into 200 subintervals.

The functions and their solutions are denoted in the following way:

$1.1 \mathrm{Y}(\mathrm{J}, \mathrm{I})$ is the $\mathrm{J}^{\text {th }}$ function at the $\mathrm{I}^{\text {th }}$ position;

$1.2 \mathrm{Yl}(\mathrm{J}, \mathrm{l})$ is the derivative of the $\mathrm{J}^{\text {th }}$ function at the $\mathrm{I}^{\text {th }}$ position;

1.3 $Y(1, I)$ and $Y(2, I)$ are the linearly independent solutions of the homogeneous equation; i. e..., $R(X)=0$;

$1.4 \mathrm{Y}(3, \mathrm{I})$ is the nonhomogeneous solution;

1.5 $\mathrm{Y}(4, \mathrm{I})$ is the solution to the given problem which depends on the given boundary conditions, that is

$$
Y(4, I)=C_{1} * Y(1, I)+C_{2} * Y(2, I)+Y(3 ; I)
$$

where $C_{1}$ and $C_{2}$ are constants determined. from the boundary conditions. 
The values returned are the arrays $\mathrm{Y}(\mathrm{J}, \mathrm{I})$ and $\mathrm{YP}(\mathrm{J}, \mathrm{I})$. No output is generated by the program unless the problem is underdetermined in which case $Y(1, I), Y(2, I)$ and $Y(3, I)$ and the relationship between $C_{1}$ and $\mathrm{C}_{2}$ are printed. IER is an error return. For this program, IER $=1$ means no solution is possible for the given boundary conditions and IER $=2$ means that the equations for $C_{1}$ and $C_{2}$ are underdetermined and separate solutions are printed. 


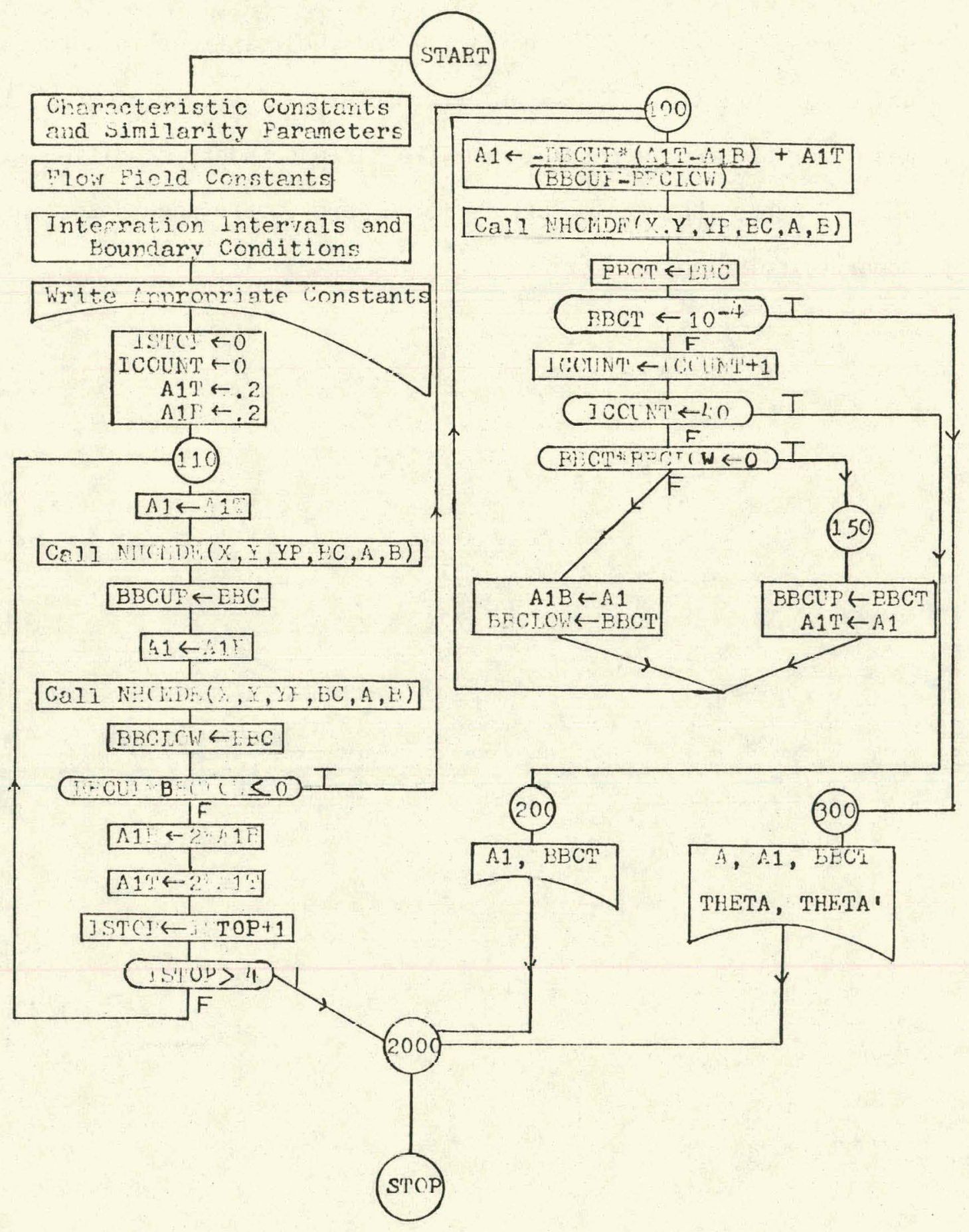

Appendix A Figure 1. Main program 


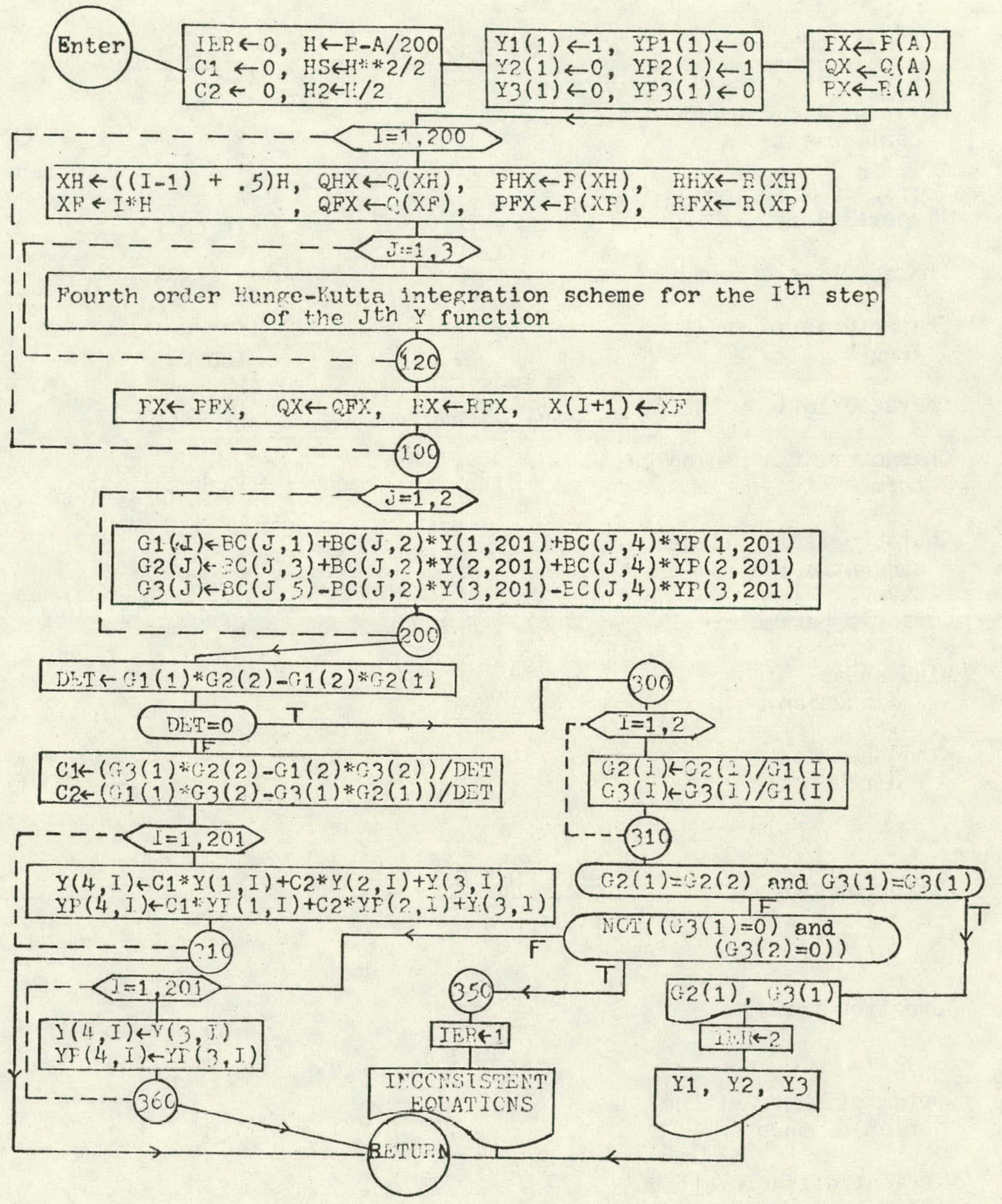

Appendix A Figure 2. NHOMDE 
Appendix B. List of Symbols and Their Values

Name

Horizontal diffusion coefficient

Vertical diffusion coefficient

Characteristic depth

Characteristic she1f length

Characteristic velocity

Characteristic biological term

Characteristic nitrate concentration

Coriolis parameter

Wind shear--

$\mathrm{X}$ direction

Wind shear--

$\mathrm{Y}$ direction

Diffusion term

Advection term

Bottom offshore attenuation exponent

Nitrient offshore attenuation exponent

Flow field offshore attenuation exponent
Symbol

Value

$\mathrm{D}_{\mathrm{L}}$

$10^{6} \mathrm{~cm}^{2} / \mathrm{sec}$

$\mathrm{D}_{\mathrm{V}}$

$10 \mathrm{~cm}^{2} / \mathrm{sec}$

$\mathrm{H}_{\mathrm{L}}$

75 meters

$\mathrm{S}_{\mathrm{L}}$

$100 \mathrm{~km}$.

PSIL

$50 \mathrm{~cm} / \mathrm{sec}$

$\mathrm{B}_{\mathrm{L}}$

$10^{-5} \mu g-a t / 1-\sec$

$\mathrm{N}_{\mathrm{L}}$

$1 \mu \mathrm{g}-\mathrm{at} / 1$

F

$10^{-4} \mathrm{sec}^{-1}$

TXS

1 dyne $/ \mathrm{cm}^{2}$

TYS

1 dyne $/ \mathrm{cm}^{2}$

$\frac{\mathrm{U}_{\mathrm{V}}^{*} \mathrm{~S}_{\mathrm{L}}{ }^{2}}{\mathrm{D}_{\mathrm{L}}{ }^{*} \mathrm{H}_{\mathrm{L}}{ }^{2}}$

$.1-5$

$\frac{\text { PSIL }^{*} S_{L}}{D_{L}{ }^{*} S_{L}}$

$.1-5$

$\alpha$

$-.4--1.2$

$\alpha_{1}$

$-3-+3$

$\alpha_{2}$ 
Name

Horizontal diffusion offshore attenuation exponent

Vertical diffusion offshore attenuation exponent

Biological offshore attenuation exponent
Symbo1

Value

$\begin{array}{cc}\alpha_{4} & .8-1.6 \\ \alpha_{5} & .4-2 \\ \alpha_{3} & 0.0\end{array}$




\section{PREVIOUS PUBLICATIONS PUBLISHED}

By

THE CENTER FOR MARINE AND COASTAL STUDIES

Wave-Current Force Spectra, C. C. Tung and N. E. Huang, Report No. 72-2, December, 1972.

A Survey of North Carolina Beach Erosion by Air Photo Methods, H. E. Wahls, Report No. 73-1, May, 1973.

Sediment Movement in Tubbs Inlet, North Carolina, Robert P. Masterson, Jr., Jerry L. Machemehl and Victor V. Cavaroc, Jr., Report No. 73-2, June, 1973.

Influence of Current On Some Statistical Properties of Waves, C. C. Tung. and N. E. Huang, Report No. 73-3, December, 1973.

CTD Sensors, Specific Conductance and the Determination of Salinity, C. E. Knowles, Report No. 73-3, August, 1973.

Planning for North Carolina's Coastal Inlets - An Analysis of the Present Process and Recommendations for the Future, William S. Tilley, Report No. 73-4, September, 1973.

A Prel iminary Study of Storm-Induced Beach Erosion for North Carolina, C. E. Knowles and Jay Langfelder and Richard McDonald, Report No. 73-5, October, 1973.

A Historical Review of Some of North Carolina's Coastal Inlets, Jay Langfelder, Tom French, Richard McDonald and Richard Ledbetter, Report No. 74-1, January, 1974.

Statistical Properties of Kinematics and Dynamics of a Random Gravity Wave Field, C. C. Tung, Report No. 74-2, June, 1974.

A New Technique of Beach Erosion Control, Tom French, Jerry L. Machemehl and N. E. Huang, Report No. 74-3, June, 1974.

Citizen Participation in North Carolina's Coastal Area Management Program, Steve Tilley, Report No. 74-4, June, 1974.

An Experimental Study of Scour Around Marine Foundations Due to Oscillatory Waves and Undirectional Currents, Greg N. Abad and Jerry L. Machemeh1, Report No. 74-5, September, 1974.

Proceedings of A Conference on Coastal Management, Report No. 74-6, September, 1974.

Statistical Properties of Fluid Motion and Fluid Force in A Random Wave Field, Keikhosrow Pajouhi and C. C. Tung, Report No. 75-1, May, 1975 
Page 2

Previous Publications Published Cont'd.

A Numerical Method for Solutions of Systems of Non-Linear Algebraic Equations, John M. Klinck and Leonard J. Pietrafesa, Report No. 75-2, JuTy, 1975.

Wave-Current Interactions in Water of Variable Depths, A. M. Radwan, C. C. Tung and N. E. Huang, Report No. 75-3, August, 1975.

Conference Proceedings Energy From The Oceans Fact or Fantasy? Jerome Koh1, Report No. 76-1, UNC-SG-76-04, January, 1976.

Long Waves Trapped by the Cape Fear Continental Shelf Topography: A Model Study of Their Propagation Characteristics and Circulation Patterns, David A. Brooks, Report No. 76-2, July, 1976.

A Comparative Study of Three Methods of Inhibiting Scour Around A Vertical Circular Cylinder, David M. Rooney and Jerry L. Machemehl, Report No. 76-3, September, 1976.

A Flow Study of Drum Inlet, North Carolina, Paul R. Blankinship, Report No. 76-4, UNC-SG-76-13 November, 1976.

Dune Stabilization with Panicum amarum Along the North Carolina Coast, E. D. Seneca, W. W. Woodhouse, Jr., and S. W. Broome, Report No. 77-1, UNC-SG-77-03, February, 1977.

A Mathematical Model of Nutrient Distribution In Coastal Waters, Eileen E. Hofmann, Leonard J. Pietrafesa, Larry P. Atkinson, Gusta.v-A. Paffenhbfer and William M. Dunstan, Report No. 77-2, February, 1977. 